\title{
EFFECTS OF VITAMIN E AND SELENIUM DEFICIENCIES \\ IN SHEEP FED A PURIFIED DIET DURING GROWTH \\ AND REPRODUCTION
}

\author{
By \\ JOCK GORDON BUCHANAN-SMI TH \\ Bachelor of Science \\ University of Aberdeen \\ Aberdeen, Scotland \\ 1962 \\ Bachelor of Science \\ Iowa State University \\ Ames, I owa \\ 1963 \\ Master of Science \\ Texas Technological College \\ Lubbock, Texas \\ 1965
}
Submitted to the Faculty of the Graduate College of the Oklahoma State University
in partial fulfillment of the requirements
for the degree of
DOCTOR OF PHILOSOPHY
May, 1969


EFFECTS OF VITAMIN E AND SELENIUM DEFICIENCIES

IN SHEEP FED A PURIFIED DIET DURING GROWTH

AND REPRODUCTION

The sis Approved:

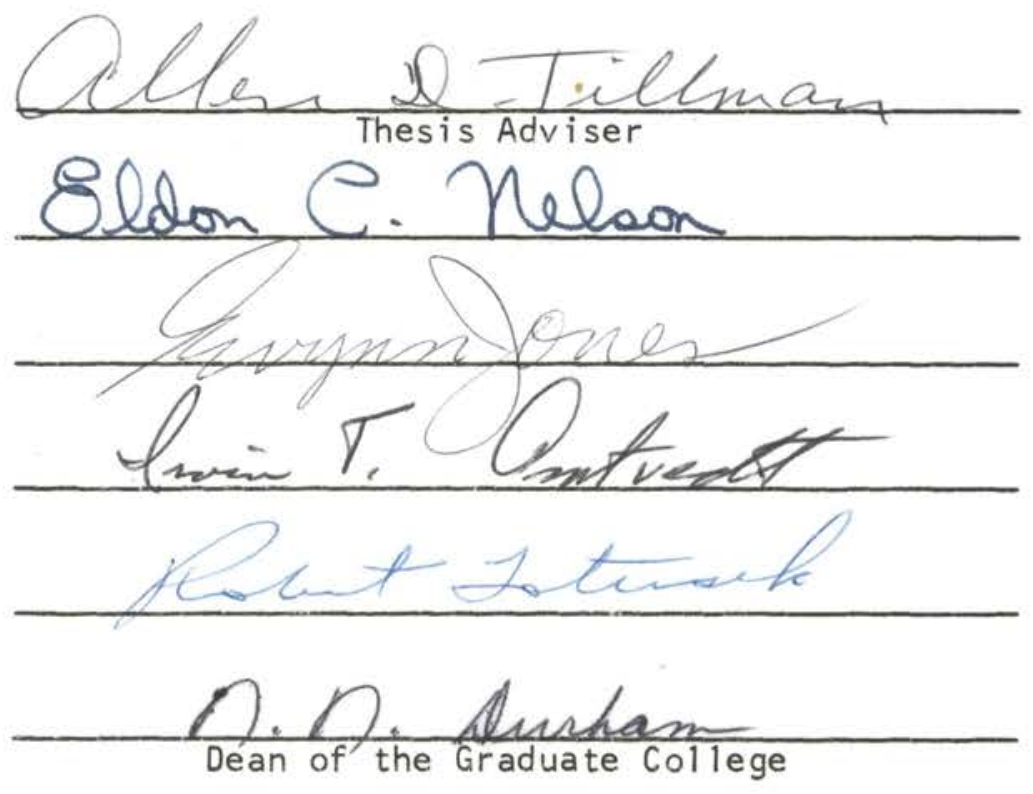

724766 


\section{ACKNOWLEDGEMENTS}

The author is most grateful to the members of his committee. Dr. Allen D. Tillman, committee chairman, both gave opportune advice and direction through the entire course of this study and was largely responsible for obtaining the necessary materials。 Dr. E。 C. Nelson provided encouragement, ideas and equipment for research on lysosomal enzymes, tocopherol and vitamin A analyses. Dr. E. W. Jones, Dr. Robert Totusek and Dr. I. T. Omtvedt also gave helpful advice on the construction of this dissertation.

Other members of the faculty and staff of Oklahoma State University gave generously of their time and talents. Dr. B. I. Osburn and Dr. Herschel1 D. Gi les performed pathological diagnoses. Dr. Joseph Smith provided advice and encouragement for research on plasma enzymes. Dr. Milton Wells collected and assisted in the analyses of ram semen. Iris McPherson computerized data analyses.

Many fellow students and others provided the resources and extra hands that were essential for the completion of this work. The following deserve special credit。 Tom Nelson gave helpful suggestions and secured equipment. John Milner contributed greatly to the collection of data. Jeannie Bennett willingly performed chemical analyses. Clara Yeck typed this dissertation.

Outside Oklahoma State University, financial support and information were donated by many groups and individuals, especially Dr. Stanley Ames, Rochester, New York. 
Last but not least, this work would never have been completed if it were not for the patience, encouragement and support of the author's wife Virginia。 
TABLE OF CONTENTS

Chapter Page

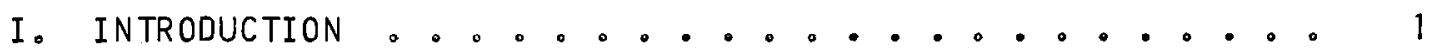

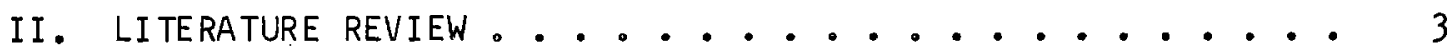

Tocopherols and Selenium . . . . . . . . . . . 3

Properties and Structure . . . . . . . . 3

Biochemical Functions............. 4

Nutrition: General ................ 9

Nutrition: Cattle, Sheep and Pigs.......... 11

Reproduction . . . . . . . . . . . . . . . . 15

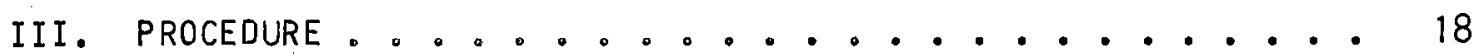

Introduction . . . . . . . . . . . . . . . 18

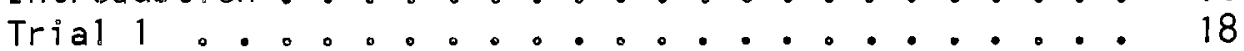

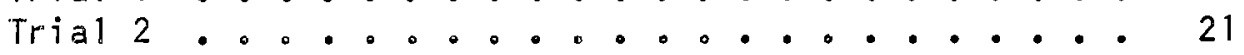

Methods of Analyses . . . . . . . . . . . . . 22

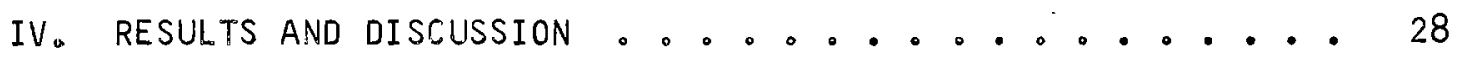

Growth and Survival . . . . . . . . . . . . 28

Reproduction in Ewes and Performance

of Thejr Lambs . . . . . . . . . . . . 30

Ram Fertility 0.0 .00000 .000 .0 .0035

Pathology 0.0 .0 .0 .0 .0 .0 .0 .0 .0 .037

Blood Tocopherols and Vitamin A Levels....... 41

Blood Hematocrit, Hemoglobin, Red Cell

Counts and Plasma Protein ... . . . . . . . 46

Plasma Enzymes 0.00 .0 .0 .0 .0 .0 .0 .048

Relative Weight of Organs . . . . . . . . . . 60

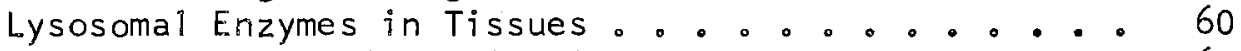

Creatine Phosphokinase in Tissues $. .0 . . . .0 .67$

Lactate Dehydrogenase and Alpha-Hydroxy

Butyrate Dehydrogenase in Tissues . . . . . . 70

Tocopherols and Vitamin A in Tissues . . . . . 75

General Discussion.0.............. 80

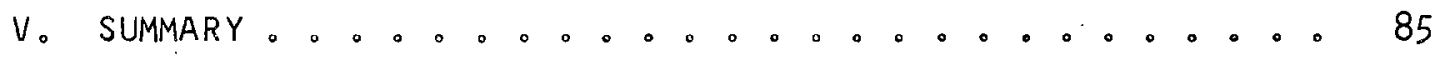

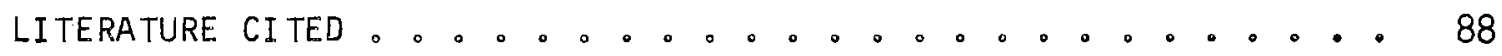

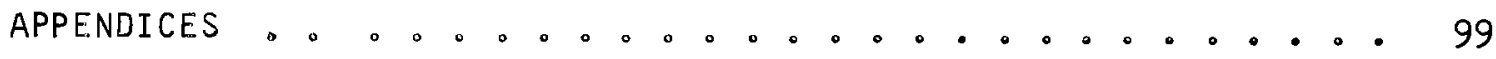


APPENDIX A . . . . . . . . . . . . . . . . 100

APPENDIX B . . . . . ................ 107

APPENDIX C . . . . . . . . . . . . . . . 109

APPENDIX D. . . . . . . . . . . . . . . . . . . 111 


\section{LIST OF TABLES}

Table

Page

I. Vitamin E-, Selenium- and Sulfur-Amino Acid-Deficiency

Symptoms in Various Mammals and the Chicken ...... 10

II. Composition of the Basal Purified Diet . . . . . . 19

III. The Effect of Vitamin $E$ and Selenium on the Average Daily Gain of the Ewes and Rams During the Initial 140 Days

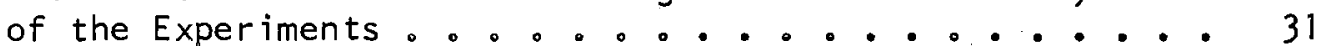

IV. The Effect of Vitamin E and Selenium on the Reproductive Performance of the Ewes . . . . . . . . . 32

V. The Effect of Vitamin $E$ and Selenium on the Average Daily Gain of the Lambs Pre- and Post-Weaning . . . . . 34

VI. The Effect of Vitamin $E$ and Selenium on Semen Characteristics................ 36

VII. The Effect of Vitamin $E$ and Selenium on the Concentration of Total Free Tocopherols in Blood Plasma of the Rams.............

VIII. The Effect of Vitamin $E$ and Selenium on the Concentration of Vitamin A in Blood Plasma of the Ewes ....................

IX. The Effect of $V i t a m i n E$ and Selenium on the Activities of Some Enzymes in Blood Plasma of the Rams .................. 54

X. The Effect of Vitamin $E$ and Selenium on the Ratio of the Activity of Alpha-Hydroxy Butyrate Dehydrogenase (HBD) to the Activity of Lactate Dehydrogenase (LDH) in Blood Plasma of the Rams .... ....... . . . . ..... 55

$X I$. The Effect of $V i$ tamin $E$ and Selenium on the Relative Weights of Liver, Heart and Kidneys in the Ewes ................... 
Table

XII. The Effect of Vitamin $E$ and Selenium on the Total

Activity, Specific Activity and Subcellular

Distribution of Acid Protease in Liver of

the Ewes........................

XIII. The Effect of Vitamin $E$ and Selenium on the Total

and Free Activity of Acid Protease and Beta-

Glucuronidase in Skeletal Muscle of the Ewes...... 65

XIV. The Effect of Vitamin E and Selenium on the Total

and Free Activity of Acid Protease and Beta-

Glucuronidase in Uterus and Placenta of the

Ewes .... . .....................

$X V$. The Effect of $V i$ tamin $E$ and Selenium on the Activity

of Creatine Phosphokinase in Skeletal Muscle,

Heart and Uterus and Placenta of the Ewes

XVI. The Effect of Vitamin E and Selenium on the Activities

of Alpha-Hydroxy Butyrate Dehydrogenase (HBD) and

Lactate Dehydrogenase (LDH) in Skeletal Muscle,

Heart and Uterus and Placenta of the Ewes

XVII. The Effect of Vitamin $E$ and Selenium on the Concentration of Total Tocopherols in Liver, Skeletal Muscle, Heart, Kidneys and Uterus and Placenta of the Ewes ........... 76

XVIII. The Effect of Vitamin E and Selenium on the Ratio

of Esterified Tocopherols to Total Tocopherols

in Skeletal Muscle, Heart, Kidneys and Uterus

and Placenta of the Ewes ...............

XIX. The Effect of Vitamin $E$ and Selenium on the Concentration of Total Free Tocopherols in Liver, Skeletal Muscle, Heart and Kidneys of the Ewes' Fetuses . . . . . . . . . . . . .

$X X$. The Effect of Vitamin $E$ and Selenium on the Concentration of Vitamin $A$ in Liver of the

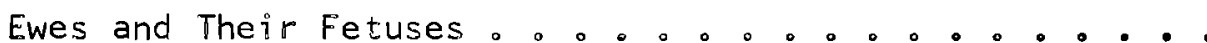

$X X I$. The Effect of Vitamin E and Selenium on the Hematocrit in the Blood of the Ewes .......... 101

XXII. The Effect of Vitamin $E$ and Selenium on the Concentration of Hemoglobin in the Blood of the Ewes 
XXIII. The Effect of Vitamin $E$ and Selenium on the Concentration of Red Blood Cells in the Blood of the Ewes ................ 103

XXIV. The Effect of Vitamin $E$ and Selenium on the Hematocrit in the Blood of the Rams ........ 104

$X X V$. The Effect of Vitamin $E$ and Selenium on the Concentration of Hemoglobin in the Blood of the Rams................... 105

XXVI. The Effect of Vitamin $E$ and Selenium on the Concentration of Protein in Blood Plasma of the Ewes ................... 106

XXVII. The Effect of Vitamin E and Selenium on the Proximate Analyses of the Ewes' Milk . . . . . 108

XXVIII. Normal Mean Values and Ranges Obtained for the Activities of Several Enzymes in Blood Plasma of Sheep ................ 110

XXIX. Standard Errors on Treatment Means for Tota1 Plasma Free Tocopherol Values Plotted in Figure 4 ....................

XXX. Standard Errors on Treatment Means for Plasma Glutamate-0xaloacetate Transaminase Values Plotted in Figure 6 ...............

XXXI. Standard Errors on Treatment Means for Plasma Glutamate-0xaloacetate Transaminase Values Plotted in Figure 7 .............. 114

XXXII. Standard Errors on Treatment Means for Plasma Creatine Phosphokinase Values Plotted in Figure 8 ......................

XXXIII. Standard Errors on Treatment Means for Plasma Alpha-Hydroxy Butyrate Dehydrogenase Values

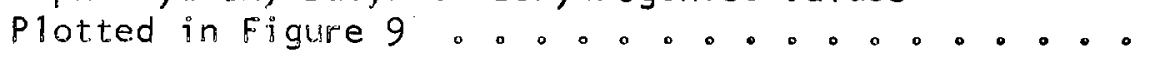

XXXIV. Standard Errors on Treatment Means for Plasma Lactate Dehydrogenase Values Plotted in 


\section{LIST OF FIGURES}

Figure

Page

1. The Effect of Time on Trial on the Occurrence of Deaths in the Vitamin E-Deficient Ewes............

2. Photomicrograph of Skeletal Muscle from One of the Ewes Showing Initial Changes Encountered in Vitamin $E$ Deficiency .......................

3. Photomicrograph of Skeletal Muscle from One of the Ewes Showing Extensive Lesions Encountered in Vitamin $E$ Deficiency......................

4. The Effect of Vitamin $E$ and Selenium on the Concentration of Total Free Tocopherols in Blood Plasma of the Ewes...

5. The Rate of Depletion of Total Free Tocopherols in Blood Plasma of Five Ewes After the Cessation of Vitamin E Treatment That Lasted 300 Days . . . . . . . . .

6. The Effect of Vitamin $E$ and Selenium on the Activity of Glutamate-Oxaloacetate Transaminase in Blood Plasma of the Ewes .......................

7. The Effect of Vitamin $E$ and Selenium on the Activity of Glutamate-0xaloacetate Transaminase in Blood Plasma of the Rams .......................

8. The Effect of Vitamin $E$ and Selenium on the Activity of Creatine Phosphokinase in Blood Plasma of the Rams ....

9. The Effect of $V i$ tamin $E$ and Selenium on the Activity of Alphamydroxy Butypic Acid Dehydrogenase in Blood Plasma of the Rams . . . . . . . . . . . . . . . .

10. The Effect of Vitamin E and Selenium on the Activity of Lactic Acid Dehydrogenase in Blood Plasma of the Rams...

11. The Effect of $V i t a m i n E$ Treatment on the Activity of Plasma Giutamate-0xaloacetate Transaminase in Vitamin E-Deficient Sheep o. . . o. . . . . . . . . . .

12. The Effect of Vitamin $E$ and Selenium on the Stability of Liver Lysosomes as Measured by the Release of Acid Protease $.0 .0 .0 .0 .0 .00 . .0 . .0 . . . .$. 
13. The Effect of Day of Gestation on the Activities of Acid Protease and Beta-Glucuronidase in the Uterus and Placenta of the Pregnant Ewes.............

14. The Effect of Age on the Activity of Lactic Acid Dehydrogenase in Skeletal and Cardiac Muscle of the Ewes' Fetuses ............. 74 
CHAPTER I

INTRODUC TI ON

It was demonstrated in 1922 that fetal resorption could be prevented by supplementing synthetic diets with lettuce or alfalfa for female rats (Evans and"Bishop, 1922). The active principle was isolated and the compound named tocopherol and assigned to vitamin E. Tocopherols are ubiquitous, occurring in all plant and animal life. However, there is no unifying hypothesis for the function of the vitamin. Among invertebrates, it differentiates sex in the rotifer (Gilbert and Thompson, 1968), and increases spermatogenic activity in crickets (Meikle and McFarlane, 1965). In vertebrates, vitamin Edeficiency symptoms are more protean than deficiency symptoms of most micronutrients. In ruminants, vitamin $E$ was found to prevent muscle dystrophy (Wiliman et al., 1945), and it is to this property that much attention has been focused. Sufficiently critical experiments to determine if vitamin $E$ might be involved in other physiological mechanisms in these animals, such as reproduction, have not been performed (Blaxter, 1962b).

Selenium was discovered by Berzelius in 1812. Up to 1940, attention in nutrition was given to its toxicity. In 1942, Schwarz found that selenium was the active principle of a compound that could prevent liver necrosis in the rat. Selenium is of great economic importance in the livestock industry because it has been found that it, and not 
vitamin $E$, will protect against some of the naturally-occurring muscular dystrophies (Hartley and Grant, 1961). Other dystrophies respond to either vitamin $E$ or selenium and some to vitamin $E$ only. Thus it is clear that the roles of these two micronutrients are probably interrelated.

The study described herein is concerned chiefly with the relationship of vitamin $E$ and selenium to reproduction in sheep. In addition, pathological and biochemical measurements were taken. 


\section{CHAPTER I I}

\section{LITERATURE REVIEW}

\section{Tocopherols and Selenium}

Properties and Structure

Tocopherols are composed of a 6-hydroxychroman derivative with a phytol side chain. The general structure is represented:

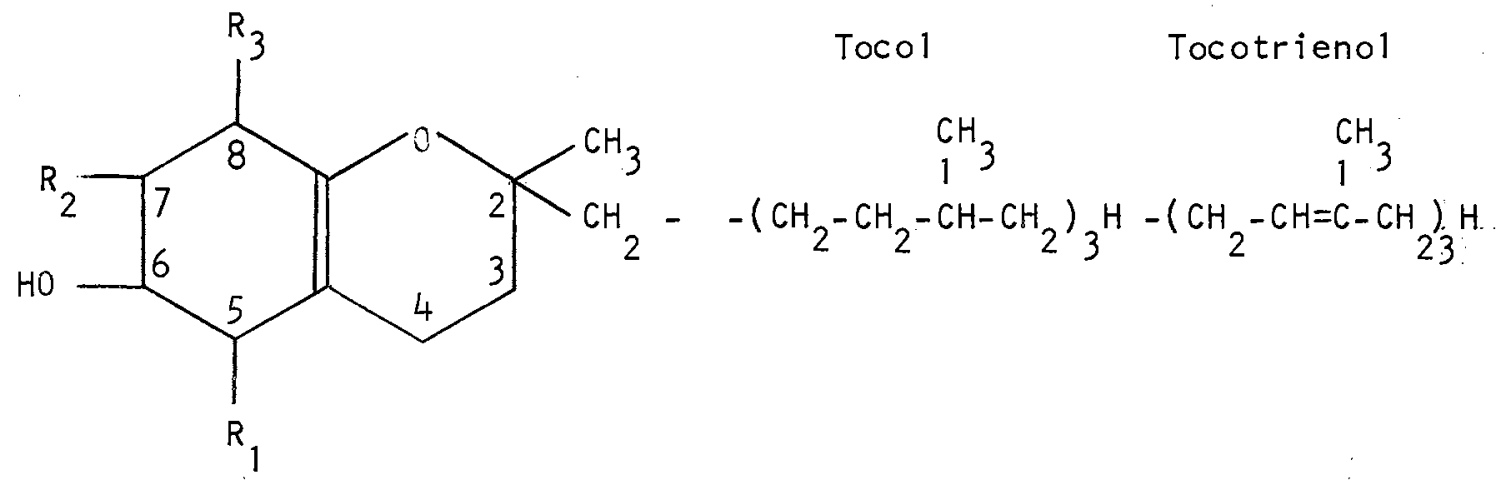

(Kofler et al., 1962)

Alpha-tocopherol, the most potent form of vitamin $E$, is a tocol containing methyl groups on al1 three positions: five, seven and eight. Tocopherols are liposoluble compounds with melting points around $0^{\circ} \mathrm{C}$. (Kofler et al., 1962). They absorb 1ight (290-300 mu) and the intensity of absorption depends on the derivative (Kofler et a1., 1962). Tocopherols may be oxidized reversibly to tocopherylquinones: 


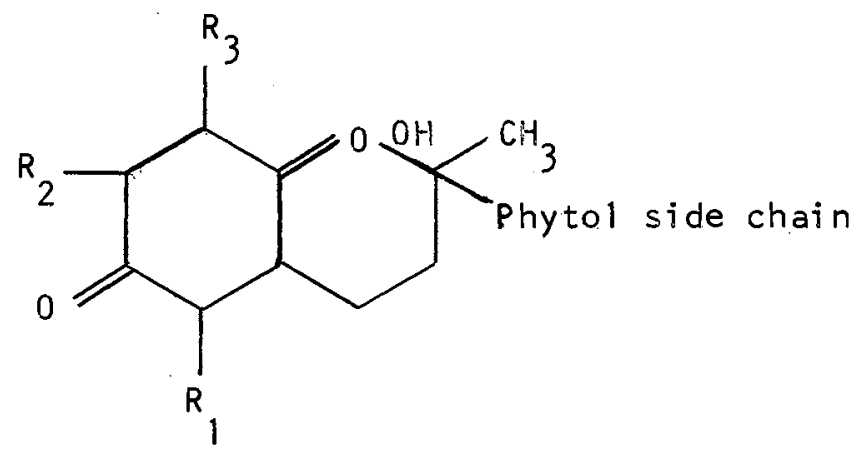

Two other metabolites of tocopherols have been isolated from urine (Simon et al., 1956).

Selenium is the element from Group VI of the periodic table, next in increasing atomic weight to sulfur. More metallic than sulfur in its physical-chemical properties, selenium nevertheless resembles sulfur in many ways. For example, it is found in trace quantities in most proteins, where it is believed to replace sulfur (Shrift, 1961).

Biochemical Functions

Degeneration of subcellular particles is one outstanding characteristic of vitamin E-deficiency lesions. For example, swel1ing. of mitochondrial cristae precedes rupture of the mitochondrion in vitamin E-deficient rabbit muscle (Van Vleet et al., 1968). Cystic degeneration of microsomes occurs in vitamin E-deficient rat liver (Schwarz, 1958). Under these conditions it is difficult to determine the primary event. At present there are two schools of thought. One school believes that vitamin $E$ and selenium are simply non-specific intrace11ular antioxidants (Tappe1, 1962). The other school believes their functions are more fundamental but no satisfactory unifying hypothesis is avai1able (Green et al. 1967)。

The antioxidant theory states that vitamin $E$ and selenium act as scavengers of free radicals; for example, peroxides of unsaturated 
fatty acids (Tappe1, 1962). Irradiation produces free radicals and it has been found that irradiated alcohol dehydrogenase is protected by the selenium-containing amino acids (Shimazu and Tappe1, 1964)。 In vivo experiments have shown that the replacement of vitamin $E$ in rat diets with synthetic antioxidants may prevent all the deficiency symptoms (Moore, 1962). Concerning comparisons made between vitamin $E$ and synthetic antioxidants in feeding trials, the following two points should be considered: first1y, the antioxidant may only be conserving dietary stores of vitamin E (Roels, 1967a). Secondly, the antioxidant may not be available to all parts of the cell (Wiss et al., 1962).

The antioxidant hypothesis explains many observed secondary effects. Increases of 1 ysosomal enzymes in rabbit (Zalkin et al., 1962) and 1 amb muscle (Desai, 1966) are thought to result from rupture of the lysosomal membrane by free radicals. Hemolysis of the erythrocyte is a similar event (Tsen and Collier, 1960). Fracture of the cell membrane by free radicals could cause the release of soluble enzymes into blood plasma (White and Hess, 1958; Blincoe and Dye, 1958). It has been suggested that the activity of gulonolactone-oxidase, the enzyme which converts guilonolactone to ascorbate, is depressed in vitamin $\mathbf{E}$ deficiency as a result of free radical proliferation (Kitabchi et al., 1960).

Many observations refute the antioxidant hypothesis. In the presence of an anti oxidant couple (ascorbic acid) in high concentration, tocopherols were still metabolized by in vitro systems (Green et al., 1967). The tissue levels of polyunsaturated fatty acids do not decline in vitamin E deficiency as would be expected if they were being utilized to form peroxides (Bunyan et al., 1967a). Five percent cod 
liver oil in diets of rats aggravates vitamin E deficiency, yet levels of cod liver oi 1 in excess of five percent are required before an increase in peroxide concentration of tissues is noticed (Bunyan et al., 1968). There are additional observations on accumulation of peroxides in tissues which are pertinent. Respiratory decline in rat liver homogenates is prevented by $v i$ tamin $E$ or synthetic antioxidants yet peroxides continue to appear after respiration has been restored to normal (Corwin, 1960). In dialuric acid-induced hemolysis of the rat erythrocyte, peroxides appear only after the erythrocyte has been treated with dialuric acid (Tsen and Collier, 1960). If peroxides are the antagonistic intermediates in vitamin E deficiency, all unsaturated fatty acids which are equally liable to oxidation should aggravate deficiency of the vitamin. However this is not always the case. It has been found that linolenic acid and not linoleic acid aggravates exudative diathesis in chickens (Hutcheson et al., 1963).

There are grave doubts about the role of selenium as an antioxidant. In myopathies of young 1 ambs or calves induced by feeding cod liver oil, selenium provides only partial protection (Welch et al., 1960). If protection given by vitamin $E$ resides in its antioxidant properties, selenium should be able to replace the vitamin in the diet since selenium has 50 to 100 times the in vitro antioxidant activity of vitamin E (Tappe1, 1962).

What are some of the available al ternatives to the antioxidant hypothesis? The tocopherols have similar structure to the ubiquinones, for example ubiquinone-50: 


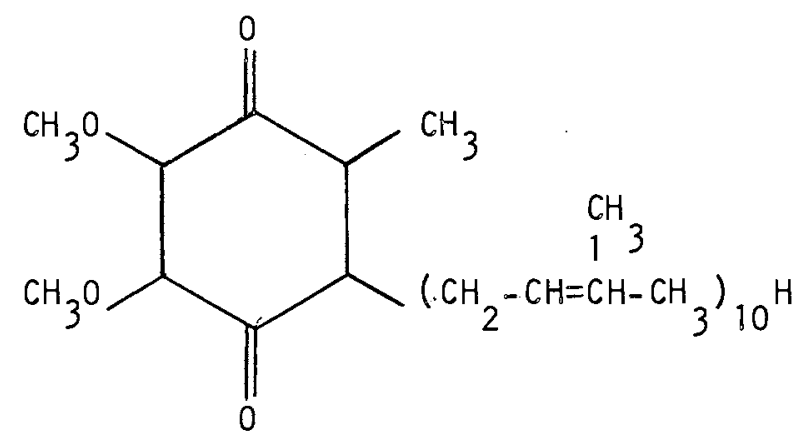

which may be reduced to form the ubichromeno1s:

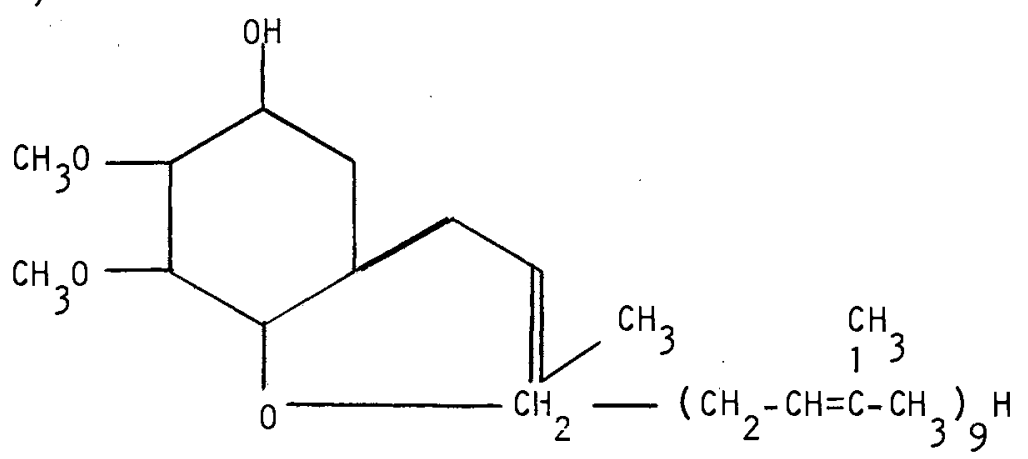

Attempts to demonstrate a metabolic pathway between the tocopherols and ubiquinones have failed (Roels, 1967b). With such a metabolic pathway, tissue levels of the ubiquinones would decline in vitamin $E$ deficiency. This has been demonstrated by Edwin et a1. (1961), and Bird and Szabo (1966)。 Others have failed to show this (Lee et al., 1965). A synthetic intermediate between alpha-tocopherol and ubichromeno1-50, ubichromanol-50, has vitamin E activity (Smith et al., 1963). Ubichromanols do not occur naturally (Roe 1s, 1967b). Ubiquinone-50 cannot replace $v$ itamin $E$ in the diet (Seidel and Harper, 1960). Ubiquinone-50 may be a component of the electron transport scheme (Green and Wharton, 1963), and in view of the oxidation-reduction states of tocopherols, it would appear a role might exist in the electron transport scheme for them also. Vasington et a1. (1960) demonstrated the presence of alpha-tocopherol in NADH-cytochrome c reductase; however, these results have not been confirmed. A failure for vitamin E- 
deficient tissue to respire has not been demonstrated, al though respiration of whole homogenates of vitamin E-deficient rat liver does decline after one hour (Chernick et al., 1955).

Prevention of respiratory decline appears to be the result of the fact that tocopherols protect critical sulfhydryl groups of liver enzymes. This protective function extends beyond their role as antioxidants (Corwin, 1960). Lipoic acid, a cofactor for alpha-ketoglutaric acid dehydrogenase, is one of the compounds protected. A deficiency of of sulfur-amino acids and selenium as well as vitamin $E$ results in liver necrosis in the rat. Sulfur-amino acids are required for the synthesis of compounds containing sulfhydryl groups (Corwin and Schwarz, 1963). Bull and 01dfield (1967) have demonstrated that selenium increases oxygen consumption of mi tochondria with alpha-ketoglutarate as substrate.

Some believe vitamin $E$ plays a more fundamental role in relation to enzymes. It has been indicated vitamin $E$ acts as a repressor in the syntheses of catabolic enzymes (01son and Carpenter, 1967), an observation which awaits ratification by others. A further effect of vitamin E at the level of protein synthesis is indicated by the observation that levels of DNA and RNA increase in vitamin E-deficient tissues (Dinning, 1962)。

No role for selenium that is entirely independent of vitamin $E$ has yet been demonstrated. Selenium increased retention of vitamin $E$ (Desai and Scott, 1965), indicating a synergism exists between the two. Both nutrients are-associated with a lipoprotein of plasma, specifically a gamma-globulin, indicating retention of vitamin $E$ to the protein in the presence of selenium. This observation is significant in support of the fact that chicks will die on selenium-deficient diets if the 
diets are not supplemented with extremely high levels of vitamin $E$ (Thompson and Scott, 1968).

It must be concluded that there are insufficient data available to suggest a unifying role for vitamin $E$ and selenium. In view of the antagonism between polyunsaturated fats and vitamin $E$ or selenium and the inclusion of polyunsaturated fats in phospholipids of membranes, further elucidation of the structure and function of membranes may clarify the area.

\section{Nutrition: General}

In contrast to selenium, very high levels of vitamin $E$ have been administered to both man (Hillman, 1957) and swine (Bratzler et al., 1950) without deleterious effects. Selenium is toxic for livestock in doses slightly higher than the minimum requirement (Rosenfeld and Beath, 1964) and is concentrated by certain plants to levels of over $100 \mathrm{ppm}$. The poisoning of ruminants with such plants results in blind staggers, or alkali disease (Rosenfeld and Beath, 1964). Selenium has a teratogenic effect if administered by injection at a high level (Kuttler et al., 1961). The sulfur-amino acids give protection against some vitamin E- and selenium-deficiency diseases. Table I presents some of the deficiency symptoms of vitamin E, selenium and the sulfur-amino acids in various mammals and the chicken.

Deficiencies in chicks and rodents result in lesions throughout the body. It is outstanding that in pigs, cattle and sheep, lesions are confined mainly to muscle and liver. 
TABLE I

VITAMIN E-, SELENIUM- AND SULFUR-AMINO ACID- DEFICIENCY SYMPTOMS IN VARIOUS MAMMALS AND THE CHICKEN

\begin{tabular}{|c|c|c|c|c|c|c|c|c|c|c|}
\hline \multirow[b]{2}{*}{ I tem } & \multicolumn{10}{|c|}{ Tissue/organ affected (and symptom of deficiency) } \\
\hline & $\begin{array}{l}\text { Skeletal } \\
\text { Musc le } \\
\text { (Dystrophy) }\end{array}$ & $\begin{array}{c}\text { Heart } \\
\text { (Dystrophy) }\end{array}$ & $\begin{array}{c}\text { Kidney } \\
\text { (Necrosis) }\end{array}$ & $\begin{array}{l}\text { Liver } \\
\text { (Necrosis) }\end{array}$ & $\begin{array}{c}\text { Fetus } \\
\text { (Resorption) }\end{array}$ & $\begin{array}{c}\text { Testis } \\
\text { (Sterility) }\end{array}$ & $\begin{array}{c}\text { Connective } \\
\text { Tissue } \\
\text { (Exudative } \\
\text { diathesis) }\end{array}$ & $\begin{array}{c}\text { Brain } \\
\text { (Encephalo- } \\
\text { malacia) }\end{array}$ & $\begin{array}{c}\text { Red } \\
\text { Blood } \\
\text { Cel1 } \\
\text { (Hemolysis) }\end{array}$ & $\begin{array}{l}\text { Teeth } \\
\text { (Depig- } \\
\text { mentation) }\end{array}$ \\
\hline \multicolumn{11}{|l|}{ Species } \\
\hline Rat & $a_{3}(b)$ & $a_{,}(b)$ & $a, b$ & $a, b$ & a & a & & & a & a \\
\hline Mouse & $a, b$ & $a, b$ & $a, b$ & $a, b$ & & & & & & \\
\hline Rabbit & $a$ & $\mathrm{a}$ & & b & & & & & & \\
\hline Pig & $a, b$ & $a, b$ & & $a, b$ & (a) & & & & & \\
\hline Sheep & $a, b$ & $a, b$ & & & & & & & . & \\
\hline Cow & $a, b$ & $a, b$ & & & & & & & & \\
\hline Horse & $a, b$ & & & & & & & & & \\
\hline Chicken & $a, b, c$ & & & & $a, b$ & a & $a, b$ & a & & \\
\hline
\end{tabular}

$a, b, c$. Indicates if the deficiency symptom responds to vitamin E, a; selenium, b; or sulfur-amino acids, c. Parenthesis indicates that the deficiency is suspected. A blank space indicates either that the relationship is non-existent or has not been examined. 
Nutrition: Cattle, Sheep and Pigs

There are two nutritional classes of muscle dystrophies in these species. One has been found on natural diets whereas the other has been induced artificially. The pathology and symptoms of the two diseases are similar. Naturally-occurring dystrophies have been reported from New Zealand, parts of Australia, the Pacific and Atlantic coasts of North America and Scotland. The dystrophy is associated with low selenium in the indigenous forages and it appears most readily in the newborn. In most cases, successful prophylaxis results from the administration of selenium and not vitamin E (Hartley and Grant, 1961). However, vitamin $E$ or selenium treatment for the newborn is successful. The artificially-induced dystrophies, by contrast, are responsive to vitamin $E$; selenium treatment serves merely to delay the onset of the deficiency (Blaxter, 1962a)。 The artificially-but not the naturallyinduced dystrophies are responsive to dietary antioxidant (Blaxter, 1962a; Hogue, 1958). The artificially-induced dystrophy is aggravated by unsaturated fat in the diet (Maplesdon et $a 1 . ; 1960$ ) and the naturally-induced dystrophy by sulfate-sulfur (Muth et al., 1961). Corn oil, fish oil and coconut oils have all been used as antagonists to vitamin E in synthetic diets. Lard failed to produce dystrophy in a calf diet (Maplesdon et a1., 1960), but it has been used successfully in lamb diets (Hopkins et a1., 1964). Among herbivores, lambs are less resistant than calves to the dietary stress imposed by fat (Davis and Maynard, 1938). Corn oi 1 was used in a skim milk diet for lambs, in which clinical signs of dystrophy were produced that did not respond to vitamin E (Boyd, 1968). The dystrophy in lambs produced by Erwin et al. (1961) with coconut oi 1 could be prevented by the 
antioxidant, ethoxyquin. The sulfur-amino acids and selenium did not prevent the dystrophy. Petechial hemorrhages, resembling exudative diathesis in chickens appeared on the ethoxyquin-deficient diet in this trial. Besides ethoxyquin, N,N-Diphenyl-p-phenylene diamine (DPPD) and methylene blue are other antioxidants which may replace vitamin $E$ (B1axter, 1962a); ascorbic acid, butylated hydroxytoluene and ethyl gallate cannot replace vitamin E (B1axter, 1962a).

Linoleic acid is the antagonistic compound in fats which induce muscular dystrophy in the chicken (Hutcheson et al., 1963). It appears likely that muscular dystrophy in the immature ruminant is associated wi th unsaturated fat (B1axter, 1962a) although it is not known which compound is responsible. Fat is hydrogenated by the microflora of the ruminant stomach (Shorland et al., 1957). Thus it is interesting to ask the question: is it possible to produce muscular dystrophy in the mature ruminant?

A powerful antagonist to the naturally-occurring dystrophies is sulfur. Sulfide fertilization of pastures in Finland (Andersson, 1960) and gypsum fertilization of pastures in New Zealand and Oregon increased the incidence of dystrophy (Schubert et al., 1961; Hartley and Grant, 1961). The Oregon workers demonstrated that on 1 y 0.053 percent additional sulfate-sulfur in the diets of dry lot-fed ewes was sufficient to reduce protection afforded by $0.2 \mathrm{ppm}$ supplementary selenium (Muth et al., 1961). Cornell workers have demonstrated the same effect (Hintz and Hogue, 1964); and in later experiments they found a correlation between the level of sulfur in the milk and symptoms of dystrophy in the lambs (Gardner and Hogue, 1967). In contrast, levels of sulfatesulfur in natural diets for ewes of 0.7 percent and 1.0 percent did not 
antagonize the protective effect of vitamin $E$ and selenium to dystrophy in their lambs surviving over 24 hours (Boyazoglu et al., 1967). The sulfate supplementation, however, was discontinued at lambing time although the 1 ambs were fed a creep feed containing 2.0 percent elemental sulfur. These workers did not indicate the milk levels of sulfur in their experiments.

Attempts have been made to determine other specific antagonists to the naturally-occurring dystrogenic rations. Gardner and Hogue (1967) found that autoclaving kidney beans destroys their dystrogenic activity. Autoclaving the beans increased digestibility of selenium and the content of vitamin $E$ and selenium in the ewe's milk was increased. This heat labile factor is alcohol insoluble. An alcohol soluble factor with unsaturated fatty acid properties has also been extracted (Hintz and Hogue, 1964).

No doubt, one predisposing factor for naturally-occurring muscle dystrophies is the tocopherol status of the newborn. Vitamin $E$ is poorly transported across the placenta (Dancis, 1960). Bratzler et al. (1950) and Parrish et al. (1950) have reported that vitamin E supplementation of the dam does not significantly improve tocopherol status in the newborn. It appears that factors affecting placental transport of vitamin E are presently unknown.

It has been demonstrated that vitamin $E$ enhances 1 iver storage of vitamin A in laboratory animals (Moore, 1940). It is controversial whether or not the same relationship exists in farm animals. Connecticut workers found that vitamin $E$ will conserve vitamin $A$ at high but not low levels of supplementary vitamin A (Dicks et al., 1959). In another experiment $v$ itamin $E$ increased plasma levels but did not affect 
liver storage of vitamin A (Rousseau et al., 1957).

The effects of vitamin $E$ in the rumen have not been studied extensively. It appears probable that rumen microorganisms do not synthesize vitamin E (Hungate, 1966). High levels of vitamin E prolong the 1ife span of rumen protozoa (D'Agostino, 1951). A significant finding has recently been made in regard to selenium utilization in the rumen. Rumen microorganisms could synthesize proteins containing selenomethionine from dietary selenomethionine, but not from dietary selenate or selenite (Paulson et al., 1968). The selenate or selenite was bound tightly to the proteins but the selenium was not incorporated into the protein.

It is not surprising that the requirements of vitamin $E$ for farm animals depend on a variety of conditions. Since vitamin $E$ appears to be non-toxic, levels of $80 \mathrm{I}$.U. per $45.4 \mathrm{~kg}$. body weight is the recommended daily allowance for beef cattle (N. R. C., 1963). Corne11 workers have obtained a response from selenium in chickens with only $0.02 \mathrm{ppm}$ in the diet (Scott, 1968). Selenate and selenite are both satisfactory salts of selenium to administer and benefit is obtained from oral treatment as well as injection (Hartley, 1967). No additional benefit has been obtained in farm animals using $y$ y-di seleno divaleric acid (Hartley, 1967). The latter had greater potency than selenate in prevention of liver necrosis in rats (Schwarz, 1961). Eighty $\mathrm{mg}$. of the sodium salt and $1080 \mathrm{mg}$. of the barium salt is toxic in one dose by injection (Kuttler et al., 1961). Dietary selenium levels that are considered toxic are between 5 and $10 \mathrm{ppm}$. on a chronic basis and over $20 \mathrm{ppm}$. on a shorter period (Scott, 1968). 
Reproduction

Dystrophy of muscle and other tissues are lesions mostly of growing animals. As stated above, there are significant lesions in reproducing vitamin E-deficient rats; namely, fetal resorption in the female (Evans and Bishop, 1922) and testicular degeneration in the male (Evans and Burr, 1927). In the female, resorption of the fetus takes place between day nine and 11 or midway through gestation. It is not known why vitamin E-deficiency results in fetal resorption. Testicular degeneration subsequent to $v i t a m i n E$ deficiency results from atrophy of germinal epi thelium (Evans and Burr, 1927). Similar responses to vitamin Edeficiency have been demonstrated in the chicken. If the hen is subjected to deficiency of vitamin E, embryonic death occurs during the first (Card et al., 1930) or last half (Jensen and. McGinnis, 1960) of incubation. Antioxidants were found to prevent fetal resorption in the female rat consequent upon vitamin E deficiency (Draper et a1., 1964). Antioxidants have a similar effect in chickens, but in this instance it appears likely that the antioxidant is merely conserving vitamin $E$ (Jensen, 1968). In prophylaxis of fetal resorption in the vitamin Edeficient rat, selenium is ineffective (Harris et al., 1958); however, it was found to improve hatchability in quai1 (Jensen, 1968). In the hamster, vitamin E-deficiency results in reduced litter size (Soderwall and Jacklet, 1963). There are no reports in the literature that vitamin $E$ deficiency clearly affects reproductive capacity in other species.

The reproductive failure in rats is irreversible after the first two or three days of pregnancy in the female (Cheng et al., 1961) and early in the life of the male (Evans and Burr, 1926). Vitamin E administered to vitamin E-deficient female rats after day two or three of 
pregnancy caused fetal monstrosities, in which the liver and other tissues were degenerated (King and Verma, 1967).

Early work by Gullickson and Fitch (1944) and Gullickson et al. (1948, 1949) and by Thomas et al. (1942) did not implicate vitamin $E$ in reproduction of farm animals. Nevertheless, reports are available that implicate vitamin $E$ in reproductive failure of farm animals. Field observation on farms in an area of California where muscular dystrophy was prevalent, demonstrated that vitamin $E$ and selenium treatment prevented abortions and improved neonatal vitality (Mace et al., 1963). Vitamin E therapy on similar farms in Rumania improved fertility (Lunca and Musetescu, 1966). In Minnesota, 4,400 I.U. of vitamin E in four equal doses was sufficient to prevent abortions which occurred on treatments in which the animals did not receive vitamin E (Boyazoglu et al.., 1967).

Using purified diets, Virtanen (1966) found that cattle did not cycle regularly on a ration in which the only vitamin $E$ came from a small amount of plant oilso. In another purified diet that contained only $10.27 \mathrm{mg}$. alpha-tocopheryl acetate per $\mathrm{kg}$. of feed, the same result was obtained (Matrone et al., 1965). This level of vitamin E may be insufficient, but it was found that the addition of only 5.0 percent alfalfa meal to the diet cured the reproductive difficulty. It is improbable that such a small amount of alfalfa meal would add sufficient vitamin E. Sheep maintained from weaning on a purified diet with approximately $4.4 \mathrm{I}_{0} \mathrm{U}_{0}$ vitamin $\mathrm{E}$ per $\mathrm{kg}$. failed to reproduce normally (Erlinger, 1968). The ewes conceived but the lambs were either sti11born, or born so weak that they could not survive more than a few days. In this trial, one ewe was treated with $500 I_{0} U_{0}$ of vitamin E 23 days 
before parturition and she produced a healthy lamb. In ewes which were maintained on a vitamin E- and selenium-deficient ration from the initiation of gestation, reproduction was normal (Wright and Be11, 1964). However, in those that were maintained into a second gestation, reproductive failure was encountered (Be11, 1967).

There is some evidence in the literature incriminating selenium in reproductive problems. In New Zealand, infertility in sheep has been associated with the incidence of white muscle disease (Hartley and Grant, 1961). In field trials, it was found that the administration of $5 \mathrm{mg}$. selenium or more per ewe was sufficient to reduce the incidence of barren ewes to less than 5 percent. This dose of selenium was inadequate to prevent the white muscle disease. In subsequent experiments, it was found that the infertility did not respond to vitamin $E$ (Hartley, 1963). Similar work in Oregon has demonstrated improved fertility by selenium treatment but the improvement was not so significant as that found in New Zealand (01dfield et a1., 1963).

Although there is much applied data that indicate vitamin $E$ and selenium may be involved in reproduction, conclusive results are lacking because experiments conducted have been insufficiently critical (B1axter, 1962b). Yet economic loss to livestock producers through reproductive failure remains quite significant and many of the factors affecting this are not resolved. Thus the primary purpose of these investigations was to re-evaluate the roles of vitamin $E$ and selenium in reproduction of sheep. In order to do this, a purified diet essentially devoid of both vitamin $E$ and selenium was used. 


\section{CHAPTER III}

\section{PROCEDURE}

Introduction

A two $x$ two factorial design was used in two trials to determine the effect of vitamin $E$ and selenium on growth and reproduction in sheep. The two levels of intake of vitamin $E$ and selenium were none and norma1. Diets were common to both trials and were as follows: all animals were fed a basal purified diet with urea as the sole nitrogen source (Table II) and with less than $0.005 \mathrm{ppm}$ selenium by analysis ${ }^{1}$. The diet of the vitamin E-deficient animals contained corn oil which was molecularly distilled to remove vitamin $E^{2}$. A synthetic antioxidant, ethoxyquin, was included in all diets and reagent grade minerals were used.

\section{Trial 1}

Forty-eight ewe lambs (average weight, $24 \mathrm{~kg}$. ; average age, four months) were randomly assigned to the four treatments. Vitamin $E^{2}$ (700 I. $U_{0}$ ) and selenium (one $\mathrm{mg}_{\circ}$ ) were given weekly by subcutaneous

${ }^{1}$ Method of Watkinson (1966). Courtesy W. H. Allaway, U. S. Plant, Soi 1 and Nutrition Laboratory, U.S.D.A., I thaca, N. Y.

2 Provided gratis by Distillation Products Industries, Rochester, New York, courtesy Dr. Stanley R. Ames, Director, Biochemical Research Laboratories. 
TABLE I I

COMPOSITION OF THE BASAL PURIFIED DIET

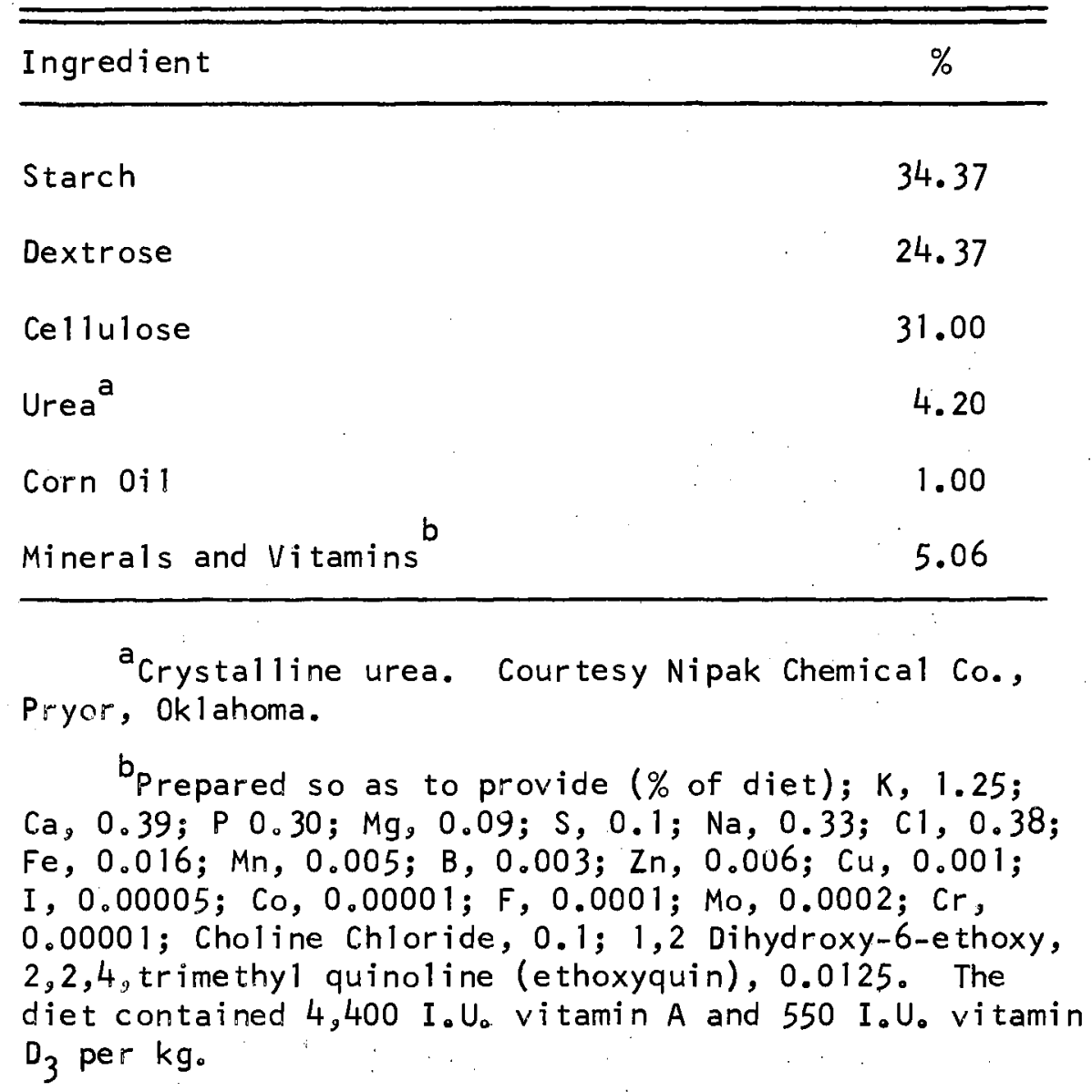


injection as dl alpha-tocopheryl acetate in a water miscible base, and sodium selenate in physiological saline, respectively. The weekly selenium dose was later increased to five $\mathrm{mg}$.

The animals were purchased locally in June, 1967 and treated with vermifuge. The sheep were housed indoors on slatted floors in wooden pens. No attempt was made to keep the environmental temperature constant. Feed assignment was ad 1ibitum throughout the growth phase but was not recorded. Water was provided ad libitum and was that provided for human consumption by the city.

Growth rate of the ewes was determined over the initial 140 days of the trial. Blood samples from half the ewes in each treatment were taken from the jugular vein into heparin at biweekly intervals. The blood was immediately piaced in ice.

At the end of the growth phase (October, 1967) several animals on the vitamin E-deficient diets died. Selenium delayed but did not prevent this. Thus, observations on reproduction were made only on those ewes that received either vitamin $E$ or those vitamin E-deficient ewes in which selenium delayed death. Six extra ewes were maintained on the vitamin E-deficient diet supplemented with selenium to compensate for early death losses on this treatment. All surviving ewes were mated to rams during November and December ${ }^{3}$. The rams were fertility tested before use and were rotated among treatments at three or four day intervals. The rams were taken from the ewes for short periods twice daily and fed alfalfa pellets. Brisket paint was used to identify mated ewes and results were recorded every twelve hours. All ewes in the trial,

${ }^{3}$ Rams courtesy Dro Robert L. Noble, Department of Animal Science. 
except one, were mated within 54 days.

At different stages of gestation, six animals on each of the three treatments in which vitamin $E$ or selenium was given, were sacrificed. Death was by exsanguination and immediately upon dissection, selected maternal and fetal tissues were removed, blotted and placed in ice-cold $0.25 M$ sucrose for immediate enzyme assays. Additional tissue samples were taken for vitamin assays and stored at $-10^{\circ} \mathrm{C}$. A thorough inspection of all tissues was made for pathological lesions and the uterus, placenta and contents were examined for abnormalities. Selected tissues were fixed in ten percent buffered formalin. They were embedded in paraffin, sectioned at $6 \mu$ and stained with hematoxylin-eosin for histopathological observations.

During gestation, blood samples were taken as before from the remaining six ewes on each treatment. These ewes were not sacrificed and if pregnant were allowed to carry fetuses to term. Milk samples were taken from these ewes two weeks after 1 ambing.

Prior to weaning at approximately ten weeks of age, no lambobtained any supplement to their dam's milk. At ten weeks of age, the lambs were then placed on the same diet and treatment as their dam. Surviv-. ing ewes were maintained on the same treatments on limited feed intake through the summer of 1968 .

Trial 2

Twe lve ram lambs (average $\mathrm{wt}_{0}, 30 \mathrm{~kg}$.) were assigned to this trial in May, 1968. Each treatment contained three individuals. Feeding and management of the rams was as described for the ewes in Trial 1, except selenium supplementation was five mg. per week throughout the 
trial. Weights were recorded for 140 days. Blood samples were collected from the rams as described in Trial 1. In October 1968, when the surviving rams had received the experimental diet for 5 months, semen was collected by electro-ejaculation at weekly intervals for five weeks and examined as described in a paragraph below.

\section{Methods of Analyses}

Microhematocrit, hemoglobin (by cyanmethemoglobin reagent. ${ }^{4}$ ) and red blood cell counts (by mechanical counter ${ }^{5}$ ) were determined on fresh blood. Plasma was harvested by centrifuging whole blood at $5000 \times \mathrm{g}$ for 20 minutes at $5^{\circ} \mathrm{C}$. and then stored at $-10^{\circ} \mathrm{C}$.

Total free tocopherols of plasma were determined by a procedure adapted from Duggan (1959). Duplicate $6 \mathrm{ml}$. plasma samples (or a volume less than $6 \mathrm{ml}$. made up to $6 \mathrm{ml}$. with deionized water) were shaken in glass stoppered centrifuge tubes for 20 minutes with $6 \mathrm{ml}$. ethano ${ }^{6}$ and $14.4 \mathrm{ml}$. petroleum ether ${ }^{7}$. Blanks (two per seven samples) were prepared identically except plasma was replaced by deionized water. Twelve $\mathrm{ml}$. of the petroleum ether layer from blanks and samples were evaporated to dryness under a stream of nitrogen and the residue dissolved in $1.5 \mathrm{~m} 1$. hexane 8 . The latter was carefully transferred to a

4Hyce1, Inc, Houston, Texas.

${ }^{5}$ Coulter Electronics, Inc., Hialeah, Florida.

6 Once distilled over $\mathrm{KOH}_{\text {。 }}$ Mo

7 Nanograde, b.P. $30-60^{\circ} \mathrm{Cos}$ Mallinckrodt Chemical Works, St. Louis, 8 Nanograde, Mallinckrodt Chemical Works, St. Louis, Mo. 
quartz cuvette in a spectrophotofluorometer ${ }^{9}$. Fluorescence was determined with the excitation wavelength set at $294 \mathrm{my}$ and emission at 342 mu. A suitable aliquot of standard alpha-tocophero $1^{10}$ was added to the sample and fluorescence intensity of sample plus standard recorded. Calculations of total tocopherol concentrations using this internal standard were according to Duggan (1959). The spectrophotofluorometer was adjusted so that there was a linear relationship between tocopherol concentration and fluorescence intensity.

Vitamin $A$ and carotene of plasma were determined by the procedure of Kimble (1939)。

With the exception of ornithine transcarbamylase (OCT) and isocitrate dehydrogenase (ICDH), plasma enzyme assays were performed spectrophotometrically by measuring the disappearance of NADH at 340 mu. A spectrophotometer 1 with a continuous recorder and a constant temperature water bath set at $25^{\circ} \mathrm{C}$. was used. Glutamate-oxaloacetate transaminase (GOT) and lactic acid dehydrogenase (LDH) were assayed according to Henry (1964) with the exception that dichromate blanks were not used. Alpha-hydroxy butyric acid dehydrogenase (HBD) was assayed according to El1jot and Wilkinson (1961); creatine phosphokinase (CPK) by Wiesmann et a1. (1966); diphosphofructoaldolase (FDA) by Bruns and Bergmeyer (1965); phosphofructoaldolase (PFA) by Wolf (1965); glutamate dehydrogenase (GDH) by Schmidt (1965) and glutamate-pyruvate transaminase (GPT) by Bergmeyer and Bernt (1965). ICDH was assayed spectro-

\footnotetext{
${ }^{9}$ Aminco Bowman, American Instrument Company, Inc., Silver Springs, Md.

${ }^{10}$ Distillation Products Industries, Rochester, N. Y.

11 Gi Iford Mode1 240, Gilford Instrument Labs, Ober1in, Ohio.
} 
photometrically by measuring the formation of NADPH at $340 \mathrm{mp}$ according to Freedland et a1. (1965) and OCT colorimetrically by measuring the formation of citrulline according to Carper and Roesler (1968).

Prior to performing any of the enzyme assays, conditions described in the procedures were confirmed such that zero order kinetics existed and the enzyme was the only rate-limiting step in the reaction. Heparin was shown not to interfere with any of the enzyme assays.

Plasma protein concentration was determined using the biuret method (Layne, 1957).

Total tocopherols of tissues were also assayed fluorimetrically The tissues were extracted in a high-speed omnimixer ${ }^{12}$ using a modification of the technique for vitamin A described by Thompson et al. (1949). In preliminary work using thirteen tissue samples from three different sheep, it was established that one extraction for a duration of eight minutes followed by a second for four minutes removed an average of 96 percent of the total that could be obtained by extracting for a longer time. Thus the following procedure was adopted: tissues were first prepared by one of three methods. Adult tissues were ground to a fine particle size. Fetal tissues were either chopped to a fine particle size with scissors or were partially homogenized by expulsion through a $1 \mathrm{~mm}$. stainless stee 1 screen by means of a screw press ${ }^{13}$. One to two grams of the thoroughly mixed tissue were introduced into the solvent
${ }^{12}$ Sorvali, Inc, Norwalk, Conn.
13 Harvard Apparatus, Inc, , Cambridge, Mass. 
mixture of $3.5 \mathrm{ml}$. deionized water, $7 \mathrm{ml}$. ethanol 14 and $23.5 \mathrm{ml}$. hexane ${ }^{15}$ and extracted in the omnimixer at $10^{\circ} \mathrm{C}$. for eight minutes. The organic solvent layer was removed and replaced by an additiona 115 $\mathrm{m} 1$. hexane and the sample rextracted for four minutes at $10^{\circ} \mathrm{C}$. Total tocopherols were estimated in $2 \mathrm{ml}$. aliquots of the combined organic solvent layers using the method identical to that employed for plasma. In addition, esterified tocopherols were determined in the hexane extracts of the tissues of adult sheep by the lithium aluminum hydride procedure described by Duggan (1959). Liver vitamin A and carotene were determined by the procedure of Bunnel et al. (1954).

The activities of two lysosomal enzymes, acid protease and betag1ucuronidase, were determined in liver, skeletal muscle and uterus. Liver was first partially homogenized by expulsion through a $1 \mathrm{~mm}$. stainless steel screen using a screw press ${ }^{16}$. Ten and 20 percent homogenates of liver and uterus, respective1y, were prepared in ice-cold $0.25 \mathrm{M}$ sucrose. Initially, the muscle homogenate in $0.25 \mathrm{M}$ sucrose was 20 percent, but this was later increased to 40 percent. Homogenization of liver was completed with three up and down strokes of a PotterElvehjem tissue grinder with a motor driven, grooved teflon piston. Muscle and uterus were homogenized in an omnimixer ${ }^{17}$ at high speed for 30 seconds. Total activities of the enzymes in al1 tissues were

\footnotetext{
${ }^{14}$ See footnote 6 .

${ }^{15}$ See footnote 8 .

${ }^{16}$ See footnote 13 .

17 See footnote 12 .
} 
determined by adding detergent ${ }^{18}$ to the homogenate to a final concentration of 0.5 percent. The homogenate was centrifuged at $18,000 \times \mathrm{g}$ for 30 minutes and the assays performed on suitable aliquots of the supernatant solution. Free activity of the enzymes was determined on the homogenate in the same way but without the inclusion of detergent. All tissue homogenization was carried out at $0-5^{\circ} \mathrm{C}$.

In addition, liver homogenates wi thout detergent were centrifuged at $600 \times \mathrm{g}$ for 10 minutes to determine the nuclear and ce 11 wall bound activity. A suspension of the lysosomal rich fraction of liver harvested at $18,000 \times \mathrm{g}$ was incubated in $0.25 \mathrm{M}$ sucrose at $37^{\circ} \mathrm{C}$. for 0,1 hr. or $2 \mathrm{hr}$. to test stability of the lysosome. The values obtained for enzyme released were divided by the total amount of enzyme in the lysosomal rich fraction, as found using detergent, and expressed as a percent。

Acid protease assay was performed according to Dingle et al. (1966) and one unit of activity is expressed as the amount of enzyme required to release one $\mathrm{mcg}$ o of tyrosine in one hour with hemoglobin as substrate. Beta-Glucuronidase was assayed according to Giannetto and de Duve (1955) using phenolphthalein glucuronide as substrate and measuring the released phenolphthalein by the method of Tappel et al. (1962). Protein of homogenate supernatants was determined according to Lowry et a1. (1951).

CPK, LDH and HBD were determined on suitable aliquots of the muscle and uterus supernatants obtained with and without the addition

${ }^{18}$ Triton X-100, Rohm and Haas, Phi ladelphia, Pa. 
of detergent ${ }^{19}$. Procedures used for these assays were identical to those applied for plasma.

Dry matter and ash of milk samples were determined according to AOAC (1960). Protein was by Kjeldah1 and fat by the Babcock test. A qualitative examination of semen was made for sperm concentration and presence of any major abnormalities. Sperm cells were stained by the nigrosin-eosin method to determine the percent live and percent with normal morphology (Hancock, 1952). Seminal plasma citrate was determined according to Saffran and Denstedt (1948) and fructose by Roe (1934).

Analyses of variance were used to determine standard errors on treatment means. Differences between treatment means were tested by multiplying the standard error wi th the appropriate significant studentized range.

${ }^{19}$ See footnote 18 . 
CHAPTER IV

\section{RESULTS AND DISCUSSION}

Growth and Survival

A11 the ewes on the basal treatment died between the 140 th. and 230 th. days of Trial 1 (Figure 1). Selenium increased survival time but did not prevent death; three ewes died by the 230 th day and a cumulative total of six by the 305 th. day. Only one of the original 18 ewes placed on this treatment survived 500 days. A similar result was obtained in Trial 2 in which all the rams on the basal treatment died between the $80 \mathrm{th}$. and $155 \mathrm{th}$, day. One ram treated with selenium died after 178 days and others survived beyond 200 days. Treatment with vitamin E prevented the deaths of three of the ewes on the basal ration in Trial 1 . All animals showed very few outward symptoms of vitamin E deficiency until shortly before death; i.e., there was no stiffness, lameness or other sign of muscular degeneration. Animals dying at a younger age did so after being prostrate for a period of from twelve to forty-eight hours. During this time, they continued to eat and drink. In older animals death was more sudden.

External condition of the animals prior to death appeared to be normal, other than for weight loss in the last few days of 1 ife. Postmortem examination revealed muscle necrosis in all dead animals, but other tissues were involved, especially in the older animals. It appeared that the ultimate cause of death was heart failure. However, 


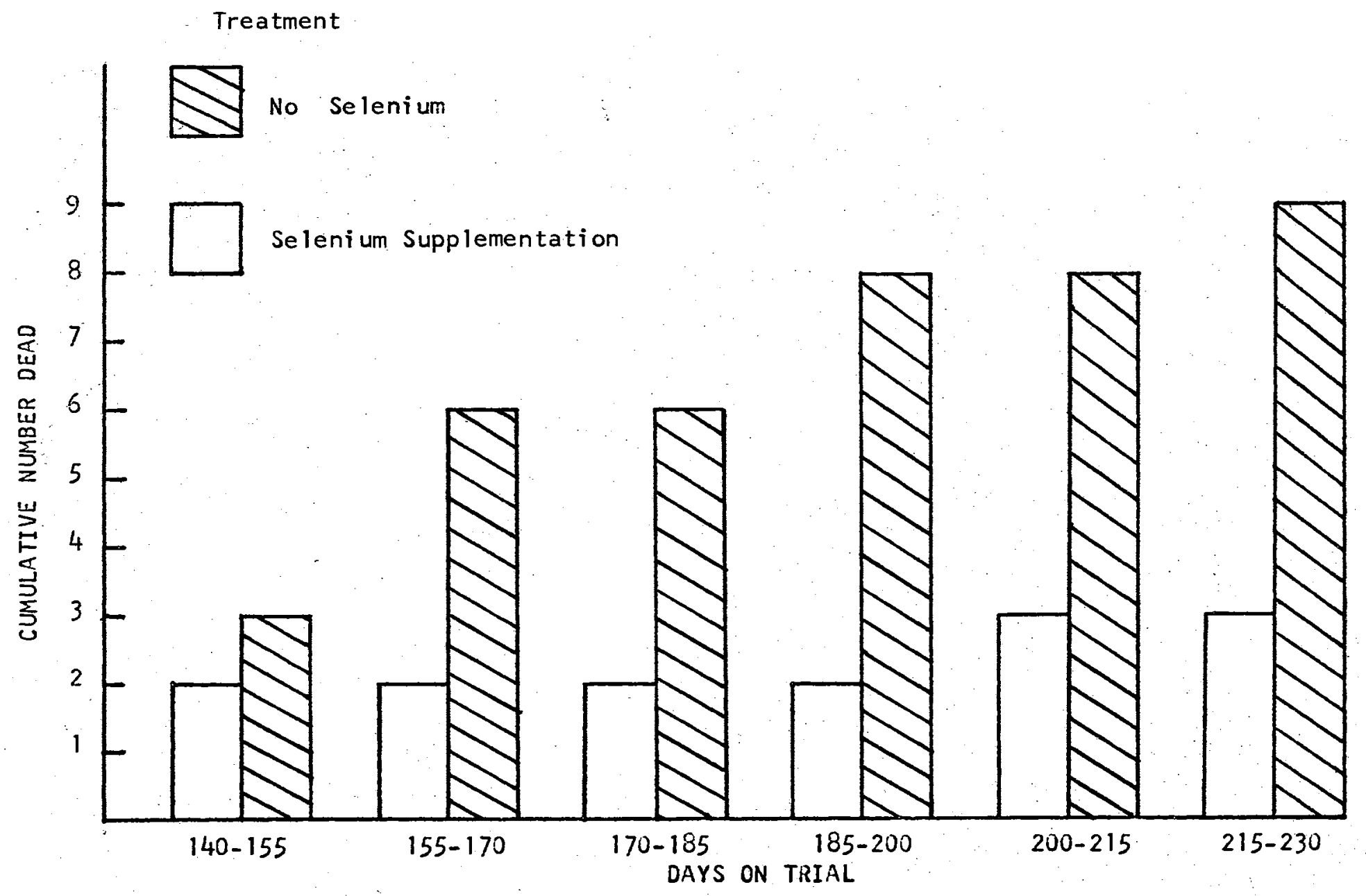

Figure 1. The Effect of Time on Trial on the Occurrence of Deaths in the Vitamin EDeficient Ewes (Twelve ewes were originally placed on each treatment. Three ewes on the basal treatment which were given vitamin E survived.). 
necrotic heart tissue was clearly identified only in animals on the basal treatment. Detailed description of the pathology of these animals is given below.

Although no adult animal receiving both vitamin $E$ and selenium died in this trial, two ewes treated with vitamin E died at the time of lambing. The cause of death seemed to be complicated but heart muscle necrosis was identified in one ewe.

In Trial 1 (Table III), selenium improved gain $(P<.10)$ while vitamin $E$ depressed it $(P<.05)$. There was no interaction between vitamin $E$ and selenium. Selenium appeared to exert a beneficial but not significant effect on yearling weights of the ewes. Rams treated with selenium gained faster $(P<.05)$ than those rams treated wi th both vitamin $E$ and selenium.

Reproduction in Ewes and Performance of Their Lambs

Conception was lower in the vitamin E-deficient treatments (Table IV). This result is a reflection upon the lack of survival of the ewes. A greater percentage of ewes treated with vitamin $E$ conceived during the first estrus than ewes on the other treatments.

The percentage of sacrificed ewes containing live fetuses was lower for ewes treated with both vitamin $E$ and selenium than for other ewes. An explanation concerns the fact that three of the sacrificed ewes treated with vitamin $E$ and selenium were not pregnant; however, all of those that were not sacrificed were pregnant. All fetuses taken in this trial except one were alive; the dead one was from a ewe treated with selenium. All three ewes, which were originally on the basal treatment and then were given vitamin E conceived. Although one 
TABLE III

THE EFFECT OF VITAMIN E AND SELENIUM ON THE AVERAGE

DAILY GAIN OF THE EWES AND RAMS DURING THE

INITIAL 140 DAYS OF THE EXPERIMENTS

\begin{tabular}{|c|c|c|c|c|c|}
\hline \multirow[b]{2}{*}{ I tem } & \multicolumn{4}{|c|}{ Treatment } & \multirow[b]{2}{*}{$S E^{a}$} \\
\hline & Basal & $\begin{array}{c}\text { Basal } \\
+ \\
\mathrm{Se}\end{array}$ & $\begin{array}{c}\text { Basa1 } \\
+ \\
\text { Vit. } E\end{array}$ & $\begin{array}{c}\text { Basa! } \\
+ \\
\text { Vit. E } \\
+ \\
\mathrm{Se}\end{array}$ & \\
\hline \multicolumn{6}{|l|}{ Ewes } \\
\hline Number & 12 & 12 & 12 & 12 & \\
\hline Av. daily gain, gm. & $107.1^{b, c}$ & $120.2^{b}$ & $92.8^{c}$ & $105.8^{b, c}$ & 6.7 \\
\hline \multicolumn{6}{|l|}{ Rams } \\
\hline Number & $-^{d}$ & 3 & 3 & 3 & \\
\hline Av. daily gain, gm。 & & $153.1^{b}$ & $134.3^{c}$ & $87.6^{c}$ & 11.9 \\
\hline
\end{tabular}

${ }^{\text {a }}$ Standard error of treatment means.

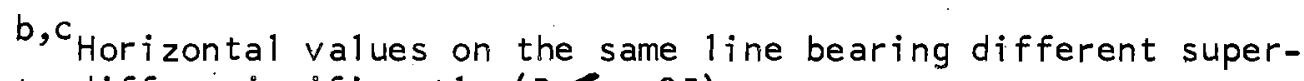
scripts differ significantly $(P<.05)$.

${ }^{d}$ Rams who were on the basal treatment died. 
TABLE IV

THE EFFECT OF VITAMIN E AND SELENIUM ON THE REPRODUCTIVE PERFORMANCE OF THE EWES

\begin{tabular}{|c|c|c|c|c|}
\hline \multirow[b]{2}{*}{ I tem } & \multicolumn{4}{|c|}{ Treatment } \\
\hline & Basa 1 & $\begin{array}{c}\text { Basal } \\
+ \\
\mathrm{Se}\end{array}$ & $\begin{array}{l}\text { Basal } \\
+ \\
\text { Vit. E }\end{array}$ & $\begin{array}{c}\text { Basal } \\
+ \\
\text { Vit. E } \\
+ \\
\text { Se }\end{array}$ \\
\hline Number of ewes & 12 & 12 & 12 & 12 \\
\hline $\begin{array}{l}\text { Conception in: } \\
\text { First estrus } \\
\text { Second estrus } \\
\text { Third estrus } \\
\text { Total }\end{array}$ & 1 & $\begin{array}{l}3 \\
3 \\
1 \\
7\end{array}$ & $\begin{array}{r}9 \\
1 \\
10\end{array}$ & $\begin{array}{l}4 \\
4 \\
1 \\
9\end{array}$ \\
\hline $\begin{array}{l}\text { Post-conception } \\
\text { Fetuses alive at sacrifice } \\
\text { Lambs alive at birth } \\
\text { Lambs weaned }\end{array}$ & $\begin{array}{l}0 \\
0 \\
0\end{array}$ & $\begin{array}{l}4 \\
4 \\
2\end{array}$ & $\begin{array}{l}5 \\
3 \\
1\end{array}$ & $\begin{array}{l}3 \\
5 \\
5\end{array}$ \\
\hline
\end{tabular}

${ }^{a}$ Six ewes were sacrificed during gestation. 
of these three ewes gave birth to a live lamb, another produced an abnormally developed one, weighing only $273 \mathrm{gm}$, at term. The third ewe aborted her fetus after 70 days of pregnancy. One other ewe treated with vitamin E also aborted a lamb after 109 days of pregnancy. It appeared probable that one ewe, on the basal treatment, resorbed her fetus. This ewe died 63 days after conception. No ewe had multiple births. The mean gestation times were estimated to be $145.5,144.3$ and 142.0 days, respectively, for ewes treated with selenium, vitamin $E$ and both vitamin $E$ and selenium. These are slightly shorter than values reported in the $1 \mathrm{i}$ terature (Forbes, 1967).

Fetal size and birth weight of lambs did not differ among treatments and values obtained agreed with those in the 1 iterature (Winters and Feuffe1, 1936)。

No lambs survived beyond weaning except those from ewes treated with both vitamin $E$ and selenium. There were two lambs born to ewes treated with selenium and one died after seven days while the second died after 56 days. Stiffness was noticeable in the second lamb only. Both of these lambs had extensive myocardial necrosis. Three of four lambs raised from ewes treated with vitamin $E$ died before weaning. The fourth lamb survived to weaning but died one day later at the age of 102 days. Unfortunately, two of these lambs were infected with coccidia and death was attributed to this infection. However, in the other two, myocardial necrosis was identified and death was attributed to this involvement. This appears to be the first report in the $1 \mathrm{i}$ terature of tissue necrosis related to selenium deficiency in experimental diets. Lambs surviving long enough to permit a comparison of pre-weaning gains (Table $V$ ), indicated no difference among those receiving vitamin 
TABLE V

THE EFFECT OF VI TAMIN E AND SELENIUM ON THE AVERAGE DAILY GAIN OF THE LAMBS PRE- AND POST-WEANINGa

\begin{tabular}{|c|c|c|c|c|}
\hline \multirow[b]{2}{*}{ I tem } & \multicolumn{3}{|c|}{ Treatment } & \multirow[b]{2}{*}{$S E^{b}$} \\
\hline & $\begin{array}{c}\text { Basal } \\
+ \\
\text { Se }\end{array}$ & $\begin{array}{c}\text { Basal } \\
+ \\
\text { Vit. E }\end{array}$ & $\begin{array}{c}\text { Basal } \\
+ \\
\text { Vit. } \\
+ \\
\mathrm{Se}\end{array}$ & \\
\hline \multicolumn{5}{|l|}{ Pre-weaning, 56 days } \\
\hline Number of 1 ambs & 1 & 4 & 5 & \\
\hline Av, daily gain, gm. & 41.1 & 142.0 & 168.8 & 45.3 \\
\hline Post-weaning, 111 days & & & & \\
\hline Number of 1 ambs & $-^{c}$ & $-^{c}$ & 5 & \\
\hline Av. daily gain, gm. & & & 11.2 .6 & 17.8 \\
\hline
\end{tabular}

${ }^{a}$ No lambs were born to ewes who were on the basal treatment.

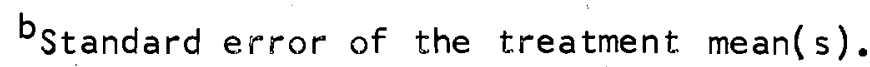

$\mathrm{C}_{\text {Lambs }}$ who were not treated with both vi tamin $\mathrm{E}$ and selenium died. 
$E$, but the lamb from one of the ewes on the selenium treatment gained poorly.

Composition of ewe's milk differed only slightly between treatments, and values obtained (See Appendix Table XXVII) were in accord with those in the $1 \mathrm{i}$ terature (Petersen, 1950).

\section{Ram Fertility}

There were no significant $(P>.05)$ differences in semen characteristics (Table VI). In each of the selenium and vitamin E treatments, one ram was unsatisfactory. The unsatisfactory animal on the selenium treatment never produced any live sperm. Upon examination of the testes, it was concluded they either were infected or otherwise injured. Live sperm from the unsatisfactory animal on the vitamin $E$ treatment were obtained on one ejaculate, and his testes were not infected or injured. One other animal on the selenium treatment produced an unsatisfactory ejaculate on one occasion. The proportions of live and normal sperm observed in semen samples taken from rams treated with selenium or vitamin $E$ are lower than that from rams treated with both vitamin $E$ and selenium but this is a direct reflection upon the infertility encountered. There were fluctuations in the concentrations of seminal citric acid and fructose. This would be a result of taking the samples by electro-ejaculation. Seminal citric acid and fructose concentration reflect upon testosterone levels in the blood (Mann, 1964). Thus it appears vitamin $E$ or selenium does not directly affect the secretion of testosterone. A similar finding has been made in the rat (Evans and Burr, 1927). 
TABLE VI

THE EFFECT OF VITAMIN E AND SELENIUM

ON SEMEN CHARACTERISTICS ${ }^{a}$

\begin{tabular}{|c|c|c|c|c|}
\hline \multirow[b]{2}{*}{ I tem } & \multicolumn{3}{|c|}{ Trea tment } & \multirow[b]{2}{*}{$S E^{b}$} \\
\hline & $\begin{array}{c}\text { Basal } \\
+ \\
\mathrm{Se}\end{array}$ & $\begin{array}{c}\text { Basal } \\
+ \\
\text { Vit. E }\end{array}$ & $\begin{array}{c}\text { Basal } \\
+ \\
\text { Vit. } \\
+ \\
\mathrm{Se}\end{array}$ & \\
\hline Number of rams ${ }^{\mathrm{C}}$ & 3 & 3 & 3 & \\
\hline \multicolumn{5}{|l|}{ Sperm } \\
\hline Concentration $^{d}$ & 1.93 & 2.13 & 3.00 & 0.75 \\
\hline Live, $\%$ & 38.1 & 43.1 & 69.0 & 17.3 \\
\hline Norma 1, \% & 52.5 & 49.7 & 83.3 & 21.0 \\
\hline $\begin{array}{l}\text { Seminal citric acid, } \\
\mathrm{mg} . / 100 \mathrm{ml} \text {. }\end{array}$ & 484.3 & 382.1 & 403.6 & 37.9 \\
\hline $\begin{array}{c}\text { Seminal fructose, } \\
\mathrm{mg} . / 100 \mathrm{ml} \text {. }\end{array}$ & 497.6 & 386.1 & 237.6 & 82.0 \\
\hline
\end{tabular}

a Rams who were on the basal treatment died.

${ }^{b}$ Standard error of the treatment means.

$c^{c}$ Five semen samples were obtained from each ram.

${ }^{d}$ Concentration score: 3 , satisfactory; 1, 2, subnormal;

0 , unsatisfactory. 
Pathology

The outstanding lesion of the vitamin E-deficient animals was muscle degeneration and necrosis. Gross lesions were not observed in animals sacrificed before the terminal stages of the disease. Also, these lesions were not observed in adult animals receiving vitamin E. The subcutaneous and interfacial tissue surrounding the affected muscle masses in the scapula and loin were infiltrated with yellow gelatinous edema. The muscles were pale or mottled and contained many 1-2 m. graywhite foci. The latter were also evident in some of the muscles from the vitamin E-treated animals. The extent of the gross lesions in, the muscle mass varied from animal to animal (Muth, 1955; Blaxter and Brown, 1952). The heavy muscles of the $1 \mathrm{imbs}$ and tongue were the most severely affected. Lesions were bilaterally symmetrical as has been previously reported (Muth, 1955; Boyd, 1964). Microscopic examination revealed typical Zenker's degeneration. Figure 2 illustrates the very early changes which are encountered. Located among some of the more normal appearing muscle fibers are swollen muscle fibers that show a loss of cross striations and fragmented sarcoplasm characteristic of hyalin degeneration. Figure 3 illustrates a section in which muscle lesions are more extensive. There are three prominent features: hyalin necrosis and mineralization of affected fibers, disappearance of fibers and hypercellularity involving macrophages, sarcolemmal nuclei and a few 1ymphocytes. The body's attempts at regeneration of sarcolemmal tubes were also observed in necrotic tissue.

Lesions in the myocardium were not as widespread as in skeletal muscle. In the vitamin Eudeficient and selenium-treated ewes the only heart lesions occurred in one of the animals which died after being on 


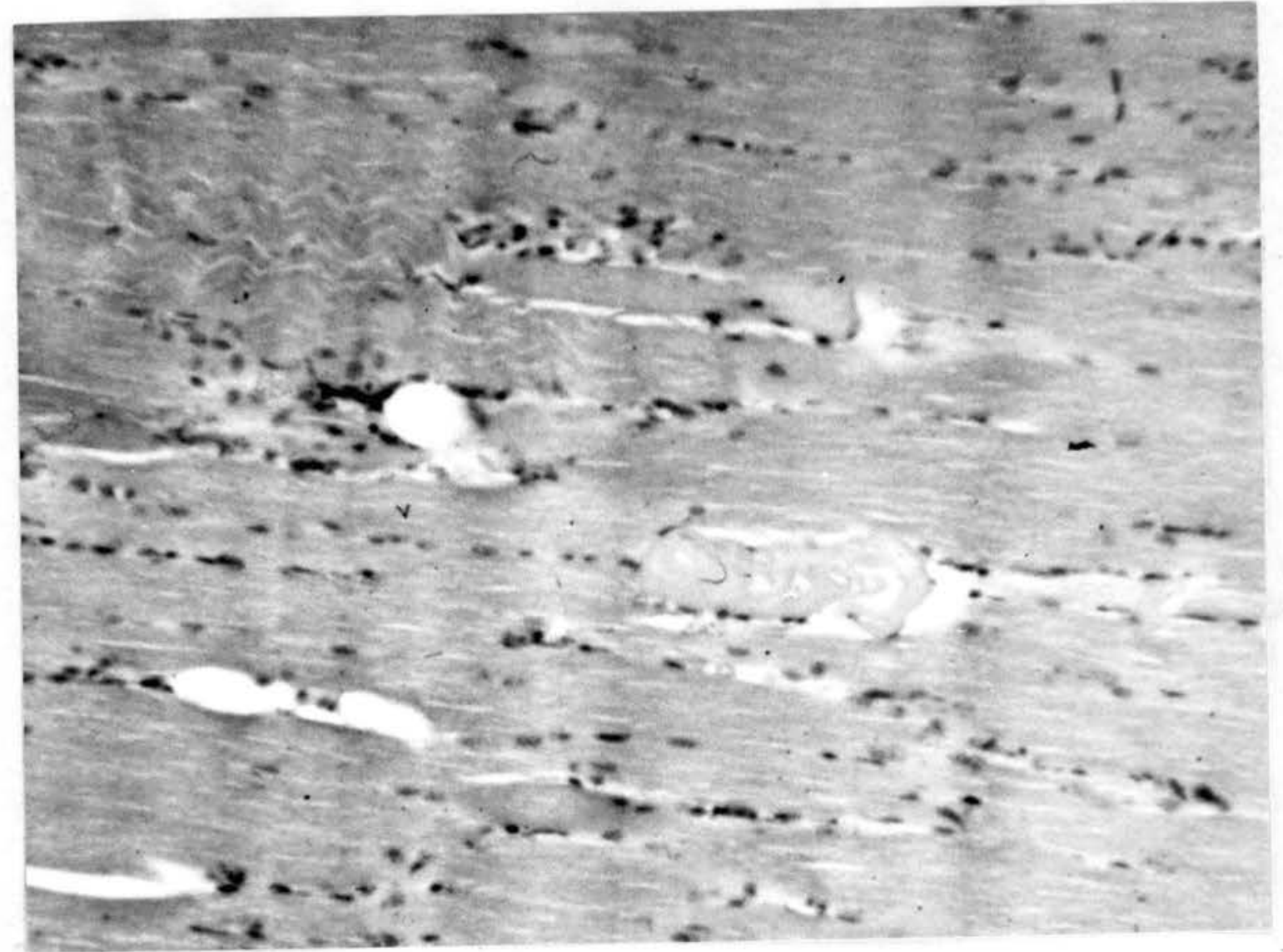

Figure 2. Photomicrograph of Skeletal Muscle from One of the Ewes Showing Initial Changes Encountered in Vitamin $E$ Deficiency (X 700) (For preparation of photomicrographs, see page 21 ). 


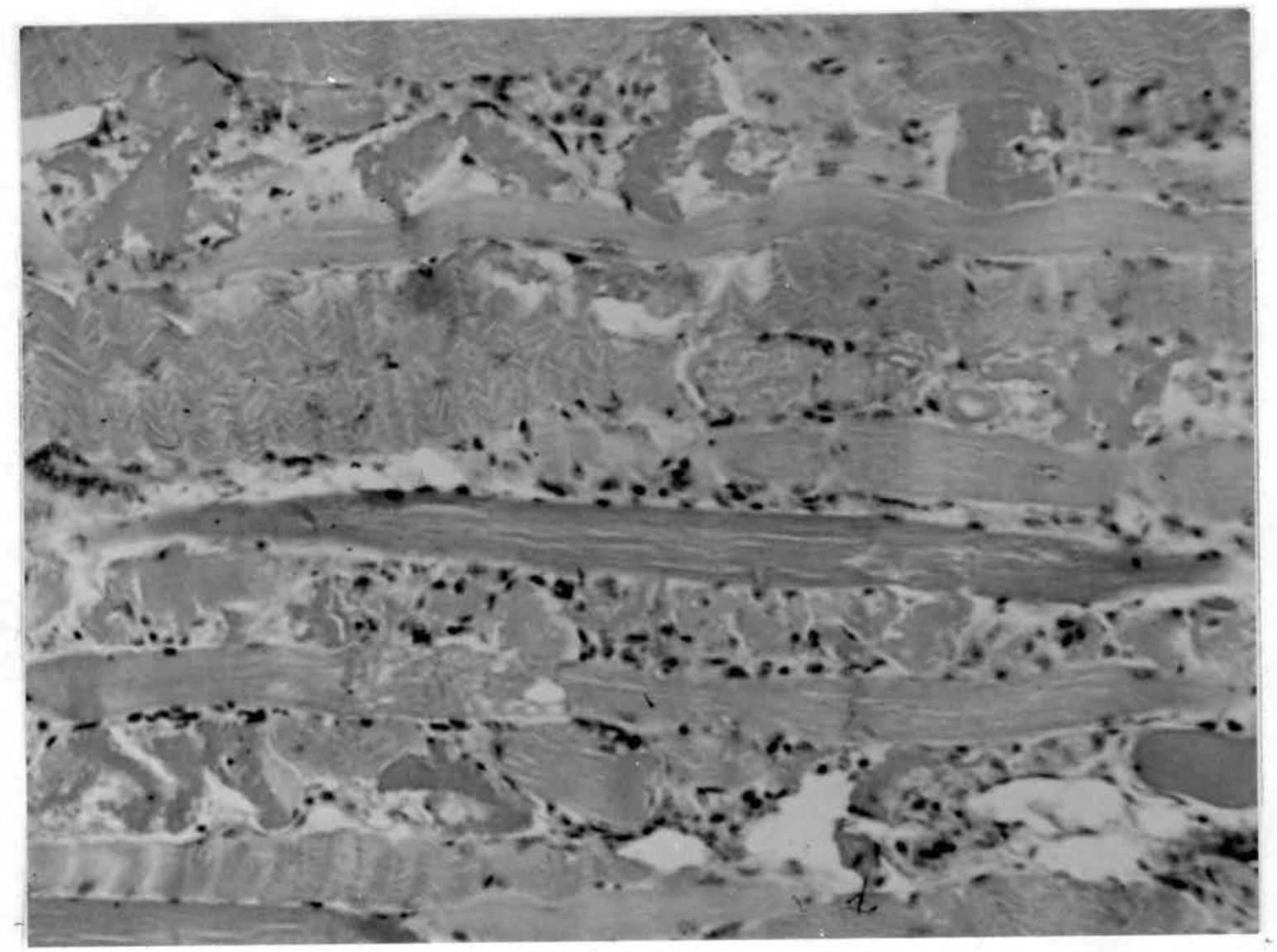

Figure 3. Photomicrograph of Skeletal Muscle from One of the Ewes Showing Extensive Lesions Encountered in Vitamin E Deficiency ( $X 700)$ (For preparation of photomicrographs, see page 21). 
experiment for one year. Several vitamin E-deficient animals died wi thout demonstrable heart lesions. The greatest occurrence of heart lesions were in the ewes fed the basal diet alone; however, there was no consistency between the extent of the disease in skeletal muscle and the occurrence of necrosis in the heart. These results confirm those of Muth (1955) and Blaxter and Brown (1952). The heart lesions appeared as 2-3 mm. by $4-5 \mathrm{~mm}$. white or whitish-yellow subendocardial plaques. Petechial hemorrhages in the subendocardium were occasionally noted. In those hearts having noticeable lesions, there appeared to be arrest in diastole Microscopic examination of the heart and skeletal muscle lesions was similar; hyalin degeneration and necrosis appearing as a prominent feature.

Gross lesions appeared in liver but were not confined to the vitamin E-deficient animals. The livers of the most severe cases were occasionally friable, mottled and otherwise discolored and usually congested. The latter was confirmed by microscopic examination. In many livers there was evidence of fatty infiltration and areas of focal necrosis. The latter occurred in many of the animals on the vitamin Edeficient treatments which died from the disease; however, it was also observed among animals treated wi th $v i \operatorname{tamin} E$ and both vitamin $E$ and selenium.

Glomerulonephritis occurred in animals from all treatment groups. In almost all the kidneys examined in this experiment, congestion, mineralization and protein depositions in the tubules were prominent. Nephrosis was clearly described only in vitamin E-deficient animals with muscle lesions. The relation of nephrosis to white muscle disease is not clear (Muth, 1955). However, since lesions similar to these 
have been produced by globin, it seems plausible to assume that these lesions are the result of the release of myoglobin from muscle (Menefee et al., 1964).

With few exceptions, lesions of other tissues were not so prominent. There were no irregularities of placentation in pregnant ewes and no testicular lesions were noticed in the rams. In the severely affected animals on the basal treatment, the spleen and thymus were often congested. In no case was necrosis of nervous tissue noticed. However, necrosis did extend to the abomasum and colon in one adult animal treated with selenium, which died after being on trial for one year. Two minor abnormalities of irregular size to muscle fiber were noticed in fetuses from ewes treated with selenium. Otherwise, the fetuses of sacrificed animals were normal. The extensive necrosis of liver that occurs in the fetuses of vitamin E-deficient rats was not observed here (King and Verma, 1967).

\section{Blood Tocopherols and Vitamin A Leve1s}

In both Trial 1 (Figure 4) and Trial 2 (Table VII), there were significant increases $(P<.01)$ in plasma free tocopherols after $v i t a-$ E treatment. The responses occurred soon after the first injection of

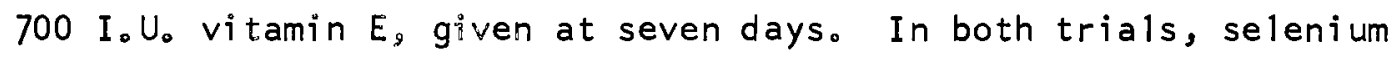
significantly $(P<.05)$ increased the tocopherol concentration in vitamin E-treated sheep soon after the first injection. This may reflect upon a greater uptake of tocopherols from the site of injection in the presence of selenium.

In contrast, selenium treatment resulted in lower $(P<.05)$ plasma tocopherol levels in vitamin E-treated ewes after 70 and 140 days on 


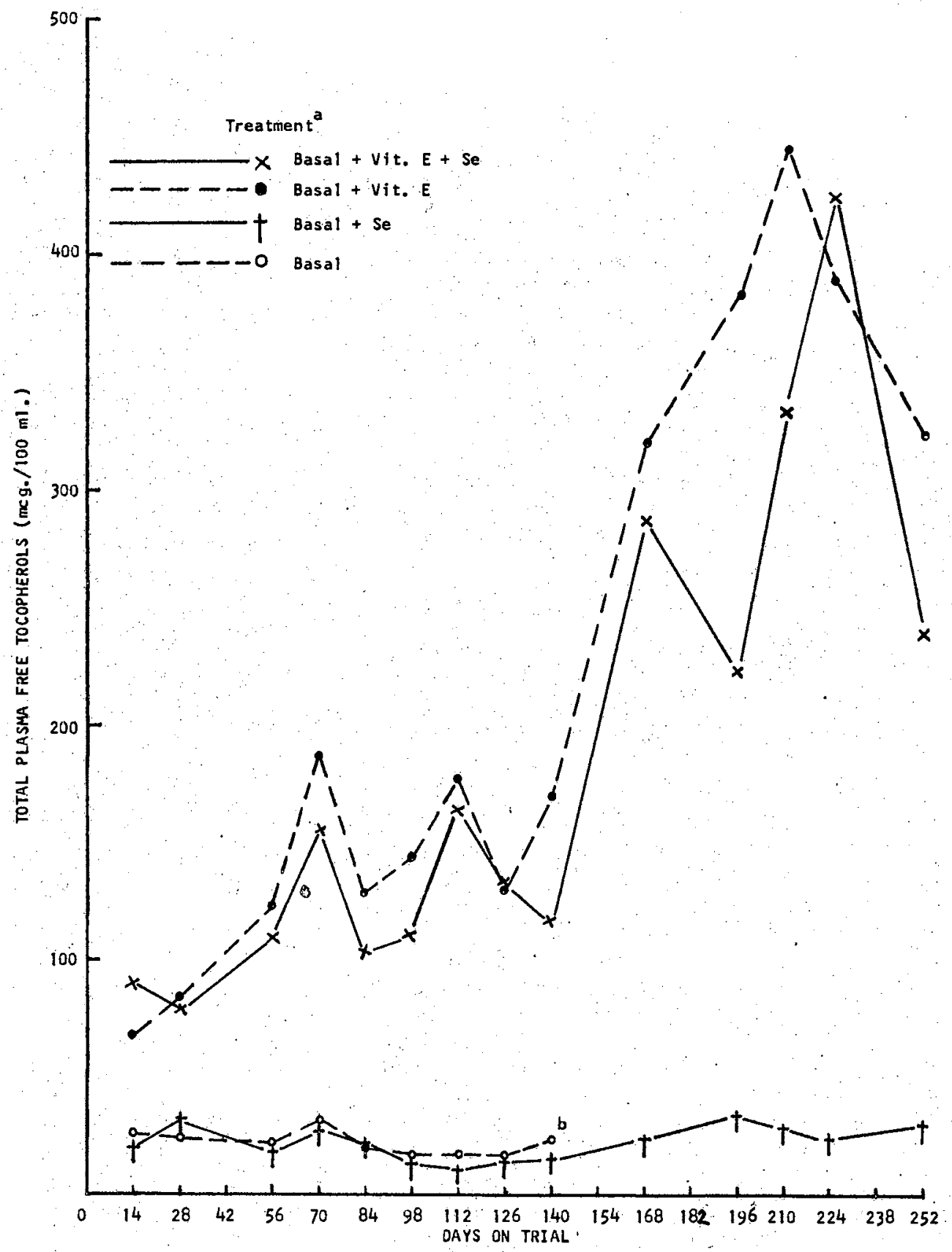

Figure 4. The Effect of Vitamin $E$ and Selenium on the Concentration of Total Free Tocopherols in Blood Plasma of the Ewes (" ${ }^{\text {SStandard errors }}$ of treatment means (each point represents a mean of six observations) are in the Appendix (Table XXIX). bEwes which were on the basal treatment died.) 
TABLE VII

THE EFFECT OF VITAMIN E AND SELENIUM ON THE CONCENTRATION OF TOTAL FREE TOCOPHEROLS IN BLOOD PLASMA OF THE RAMS

\begin{tabular}{|c|c|c|c|c|c|}
\hline \multirow[b]{2}{*}{ I tem } & \multicolumn{4}{|c|}{ Treatment } & \multirow[b]{2}{*}{$S E^{a}$} \\
\hline & Basa1 & $\begin{array}{c}\text { Basal } \\
+ \\
\mathrm{Se}\end{array}$ & $\begin{array}{c}\text { Basal } \\
+ \\
\text { Vit. E }\end{array}$ & $\begin{array}{c}\text { Basal } \\
+ \\
\text { Vit. E } \\
+ \\
\text { Se }\end{array}$ & \\
\hline Number of rams & 3 & 3 & 3 & 3 & \\
\hline \multicolumn{6}{|l|}{$\begin{array}{r}\text { Concentration, } \\
\mathrm{mcg} . / 100 \mathrm{~m} 1 \text {. }\end{array}$} \\
\hline \multicolumn{6}{|l|}{ On day: } \\
\hline 0 & 35.0 & 39.3 & 23.7 & 50.0 & 10.5 \\
\hline 14 & $31.2^{b}$ & $29.1^{b}$ & $74.2^{b}$ & $178.3^{c}$ & 29.4 \\
\hline 28 & $28.6^{b}$ & $23.1^{b}$ & $143.7^{c}$ & $147.4^{c}$ & 20.8 \\
\hline 98 & $-^{d}$ & $15.5^{b}$ & $114.1^{c}$ & $134.7^{c}$ & 18.8 \\
\hline
\end{tabular}

a Standard error of the treatment means.

$b, c$ Horizontal values on the same line bearing different superscripts differ significantly $(P<.01)$.

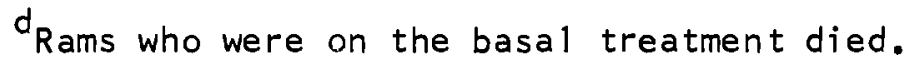


the trial. The latter effect was not found in Trial 2. Fluctuations in plasma tocopherol levels after the 140 th day may be a reflection on pregnancy which began at this time.

To test the effect of vitamin $E$ treatment upon body storage of the vitamin, tissue tocopherols were analyzed. In addition, observations were made on the decline in plasma tocopherol when vitamin E treatment ceased. Five vitamin E-treated ewes, which were of no further use in the reproduction study, were placed on a vitamin E-deficient diet after 300 days of Trial 1. The plasma tocopherol level declined gradually, thus the method of least squares was used to fit the date of Figure 5 . It appears that it would have taken between 200 and 250 days for the plasma tocopherol to have declined to the level found in sheep not treated with vitamin E during Trial 1.

The initial levels of plasma tocopherol found in the sheep which were fed a ration of natural feedstuffs prior to the initiation of these experiments were low enough to indicate vitamin E.deficiency. Thus, it appears vitamin E. deficiency may be quite prevalent under local conditions and further work should be initiated to investigate just how far this might extend.

The uptake of tocopherols from the injectible vitamin E preparation used in these experiments was tested in two wethers, in which the plasma tocopherol levels at the time of the injection were below 30 $\mathrm{mcg} / 100 \mathrm{ml}$. There was a response within 24 hours: $700 \mathrm{I}$. U. of vitamin E resulted in plasma total tocopherols of 3000 to $5000 \mathrm{mcg} . / 100 \mathrm{~m} 1$. The blood tocopherol level gradually declined from this point and after one week assumed a stationary level at approximately $100 \mathrm{mcg} / 100 \mathrm{ml}$. plasma. 


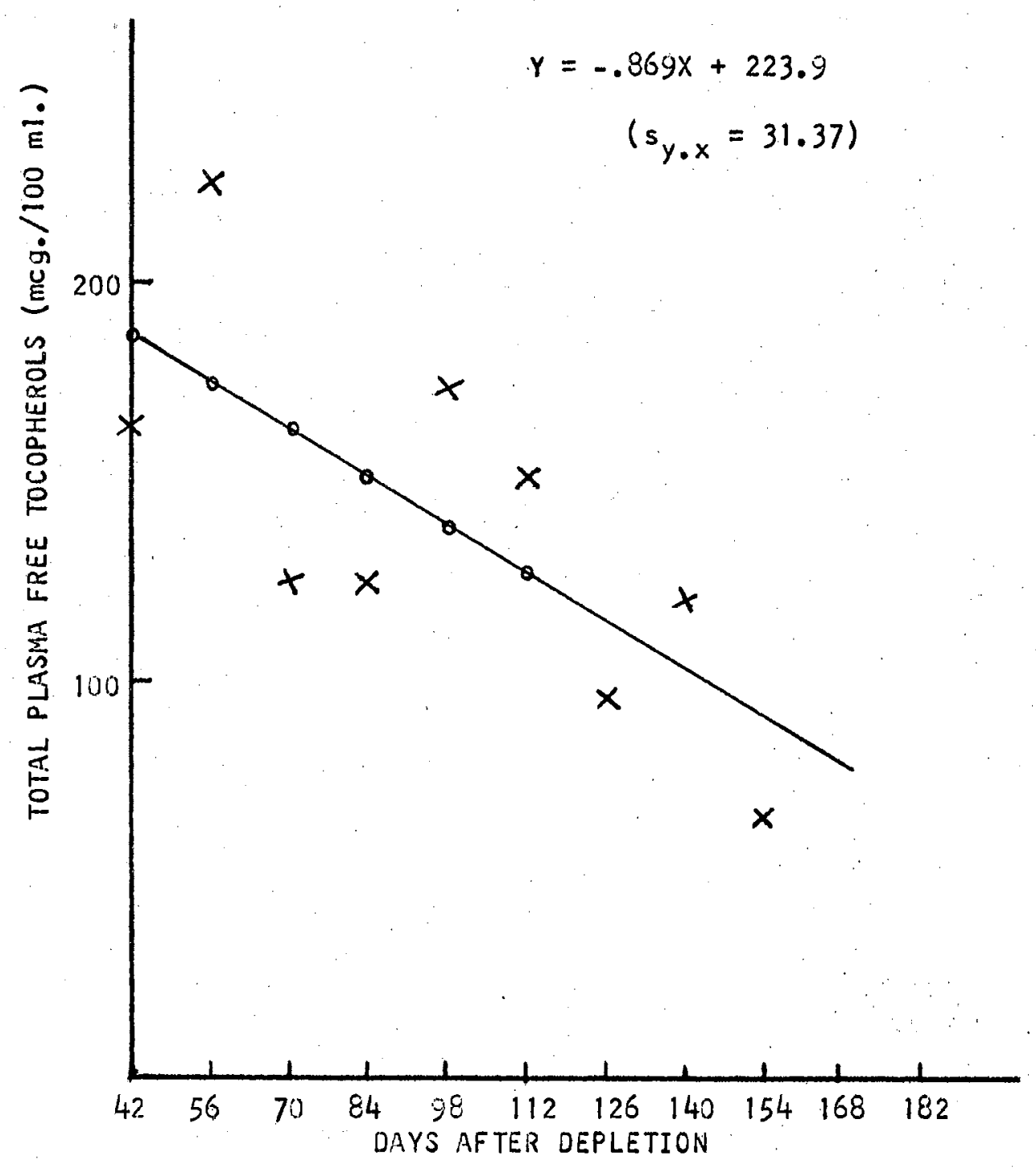

Figure 5. The Rate of Depletion of Total Free Tocopherols in Blood Plasma of Five Ewes After the Cessation of Vitamin E Treatment That Lasted 300 Days. 
Vitamin $E$ and selenium both increased $(P<.05)$ plasma vitamin $A$ levels (Table VIII). Carotenes were not found in any plasma in these experiments. Plasma levels of vitamin A found in this trial were not so $10 \mathrm{w}$ as to indicate uncomplicated vitamin A-deficiency in any animal.

Blood Hematocrit, Hemoglobin, Red Cell Counts and Plasma Protein

In the early stages of both trials, there was depression of hematocrit, hemoglobin and red blood cell concentration in all treatments (Appendix Tables $X X I-X X V$ ). This is probably a reflection upon the transition to feeding a purified diet. In Trial 1, it was calculated that the corpuscular hemoglobin concentration increased, which reflected upon the fact that the hematocrit was the most severely affected. Although this phenomenon did occur among animals on all treatments, hematocrit values were significantly lower $(P<.05)$ among animals treated with selenium after 28 days in Trial 1 and 14 days in Trial 2. Blood hemoglobin was lower among animals on the same treatments. These phenomena could be a reflection upon greater water content in the extracellular compartment. Since this appeared as an early response in the trials, and no explanation for it is apparent, further investigation in this area will be required.

After these parameters returned to normal, there were no consistent differences according to treatment, even after 300 days on the trial. In Trial 2, however, blood hematocrit and hemoglobin rose markedly $(P<.01)$ just before the animals fed the basal diet died. There were no consistent differences found in plasma protein values and these results are in the Appendix (Table XXVI). 
TABLE VIII

THE EFFECT OF VITAMIN E AND SELENIUM ON THE CONCENTRATION OF VITAMIN A IN BLOOD PLASMA OF THE EWES

\begin{tabular}{|c|c|c|c|c|c|}
\hline \multirow[b]{2}{*}{ I tem } & \multicolumn{4}{|c|}{ Treatment } & \multirow[b]{2}{*}{$S E^{a}$} \\
\hline & Basal & $\begin{array}{c}\text { Basa } 1 \\
+ \\
\mathrm{Se}\end{array}$ & $\begin{array}{c}\text { Basal } \\
+ \\
\text { Vit. } E\end{array}$ & $\begin{array}{c}\text { Basal } \\
+ \\
\text { Vit. E } \\
+ \\
\text { Se }\end{array}$ & \\
\hline Number of ewes & 6 & 6 & 6 & 6 & \\
\hline \multicolumn{6}{|l|}{$\begin{array}{c}\text { Concentration, } \\
\mathrm{mcg} . / 100 \mathrm{ml} \text {. }\end{array}$} \\
\hline \multicolumn{6}{|l|}{ On day } \\
\hline 140 & $33.4^{b}$ & $39.2^{b, c}$ & $49.7^{c}$ & $51.3^{c}$ & 4.6 \\
\hline 154 & 43.0 & 50.4 & 56.0 & 63.9 & 7.8 \\
\hline
\end{tabular}


It was observed that vitamin E deficiency resulted in several hemolysed blood samples while selenium appeared to have no effect. There is controversy concerning the phenomenon of peroxide-induced hemolysis of the erythrocyte in sheep on vitamin E-deficient diets (Boyd, 1968). It is possible that the apparent hemolysis observed in these experiments was not a result of fracture of the red blood cell but was related to myoglobin release from dystrophic muscle.

\section{P1 asma Enzymes}

General increases $(P<.05)$ occurred in the plasma levels of GOT (Figures 6 and 7), CPK (Figure 8), HBD and LDH (Figures 9 and 10), FDA and GPT (Table IX). A11 of these enzymes were elevated in response to vitamin E- not selenium-deficiency. Elevated enzyme levels were not found in any of the 1 ambs born to ewes receiving vitamin $E$, which u1timately died of heart necrosis, but blood was not sampled near the time these animals died. The data on tissue distribution of these enzymes indicate that muscle was the primary source of the enzymes in plasma (Boyd, 1962, 1964; Bruns and Bergmeyer, 1965; Wo1f, 1965; Carper and Roesler, 1967)。

Changes in the ratio, $\mathrm{HBD} / \mathrm{LDH}$, reflect upon changes in the isoenzyme pattern of LDH (E11iot and Wilkinson, 1961). A significant decrease in the ratio $(P<.01)$ occurred at 56 days in animals on the basal treatment in Trial 2 (Table $x$ ). This is indicative of an increase in proportion of the isoenzyme from skeletal muscle as opposed to cardiac muscle; thus confirming the observations of Boyd (1964) and Paulson et al., (1966).

Boyd $(1964 ; 1968)$ has reported increases of GDH in vitamin E- 


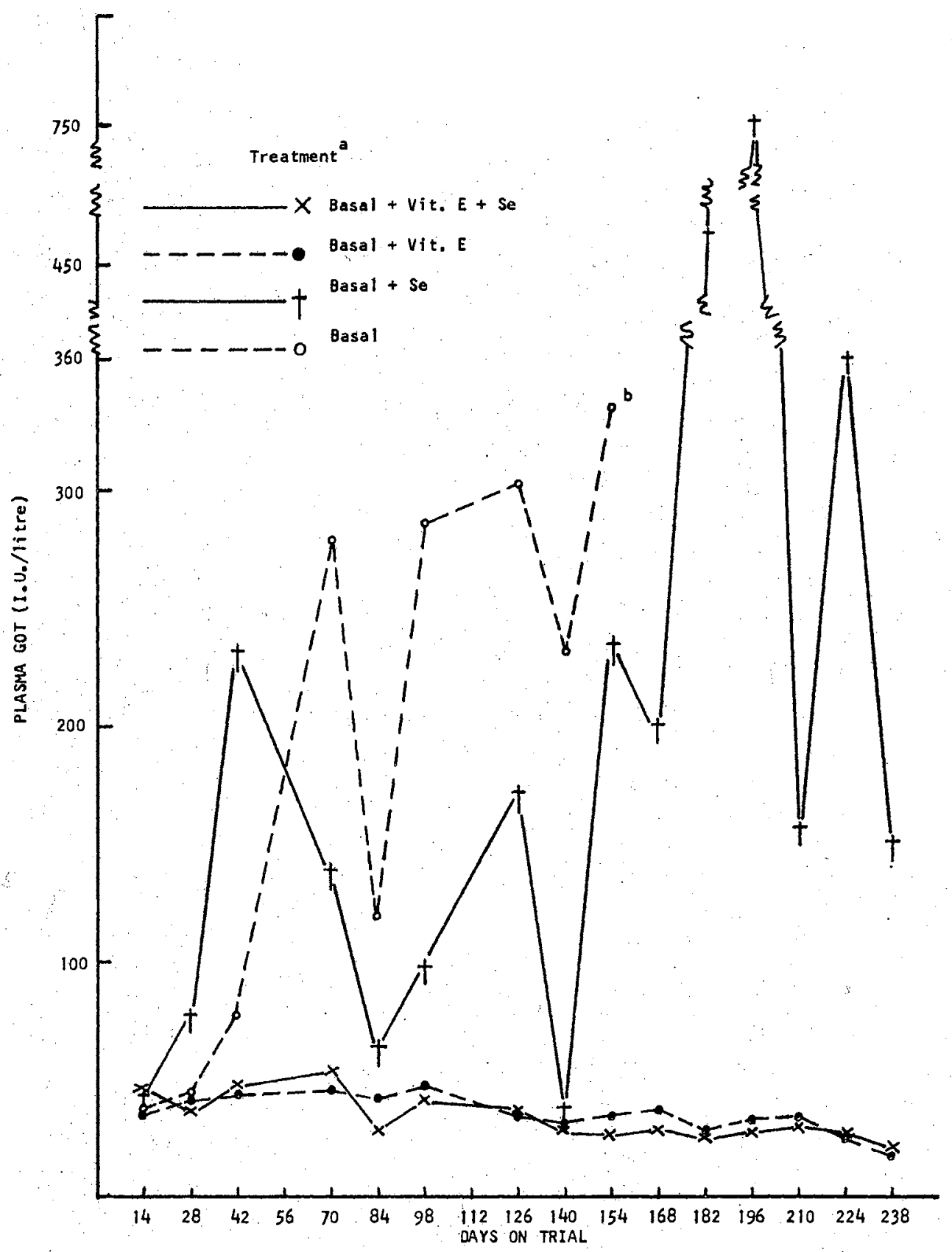

Figure 6. The Effect of Vitamin $E$ and Selenium on the Activity of Glutamate-0xaloacetate Transaminase in Blood Plasma of the Ewes. (astandard errors of treatment means (each point represents a mean of six observations) are in the Appendix (Table $X X X)$. $b_{\text {Ewes which were on the }}$ basal treatment died.) 


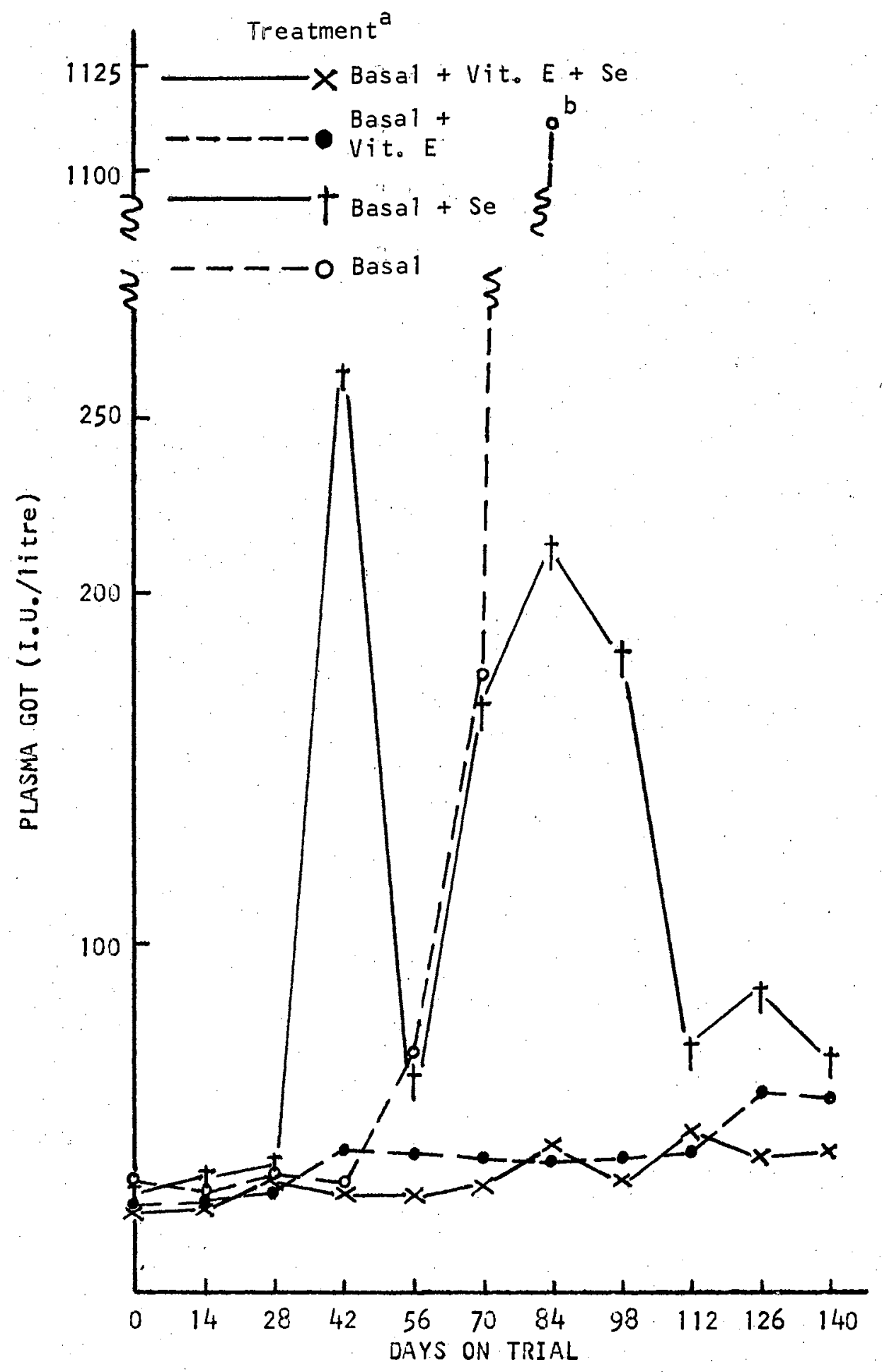

Figure 7. The Effect of Vitamin $E$ and Selenium on the Activity of Glutamate-0xaloace tate Transaminase in Blood Plasma of the Rams. (astandard errors of treatment means (each point represents a mean of three observations) are in the Appendix (Table XXXI). bRams which were on the basal treatment died.) 


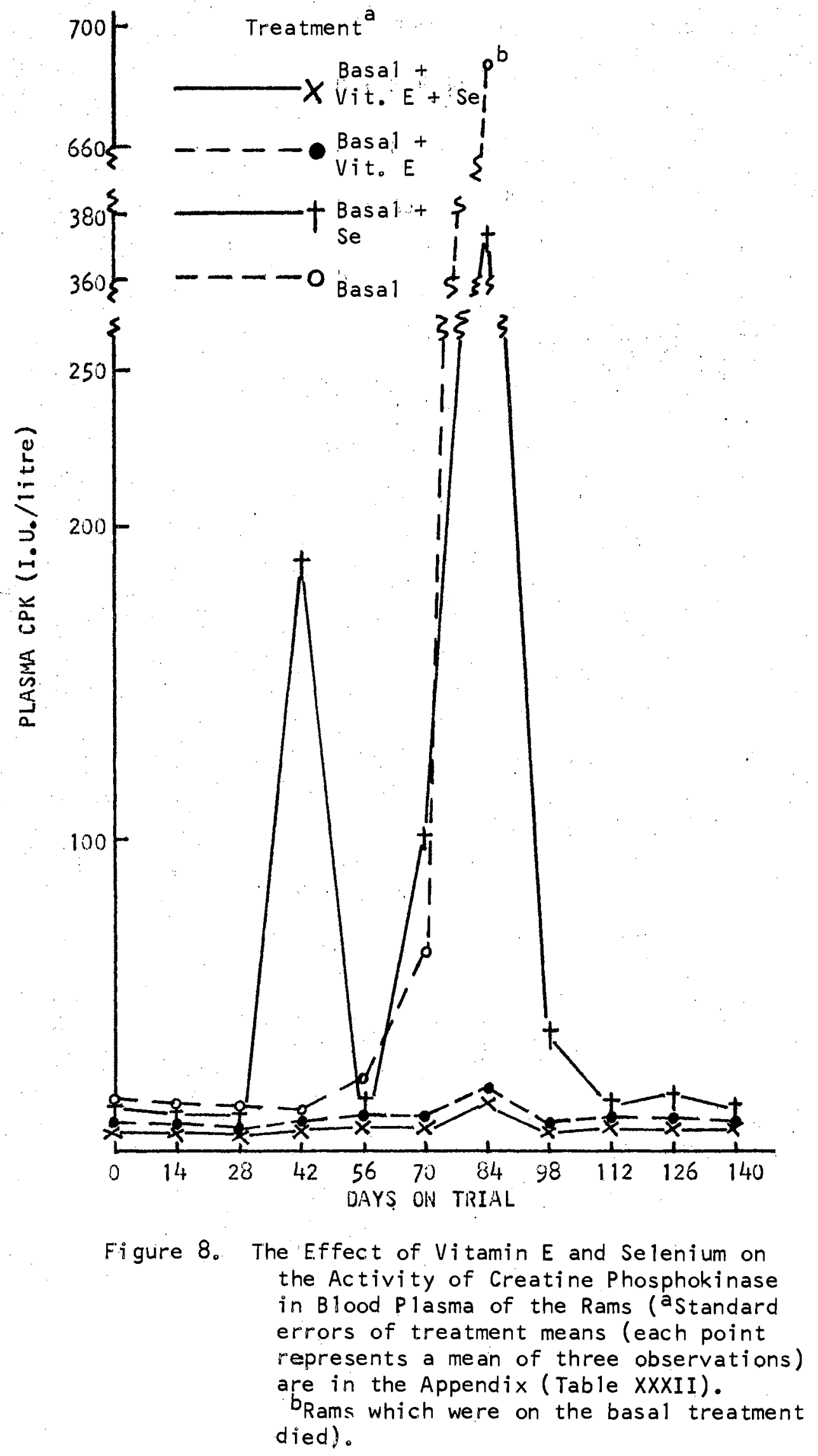




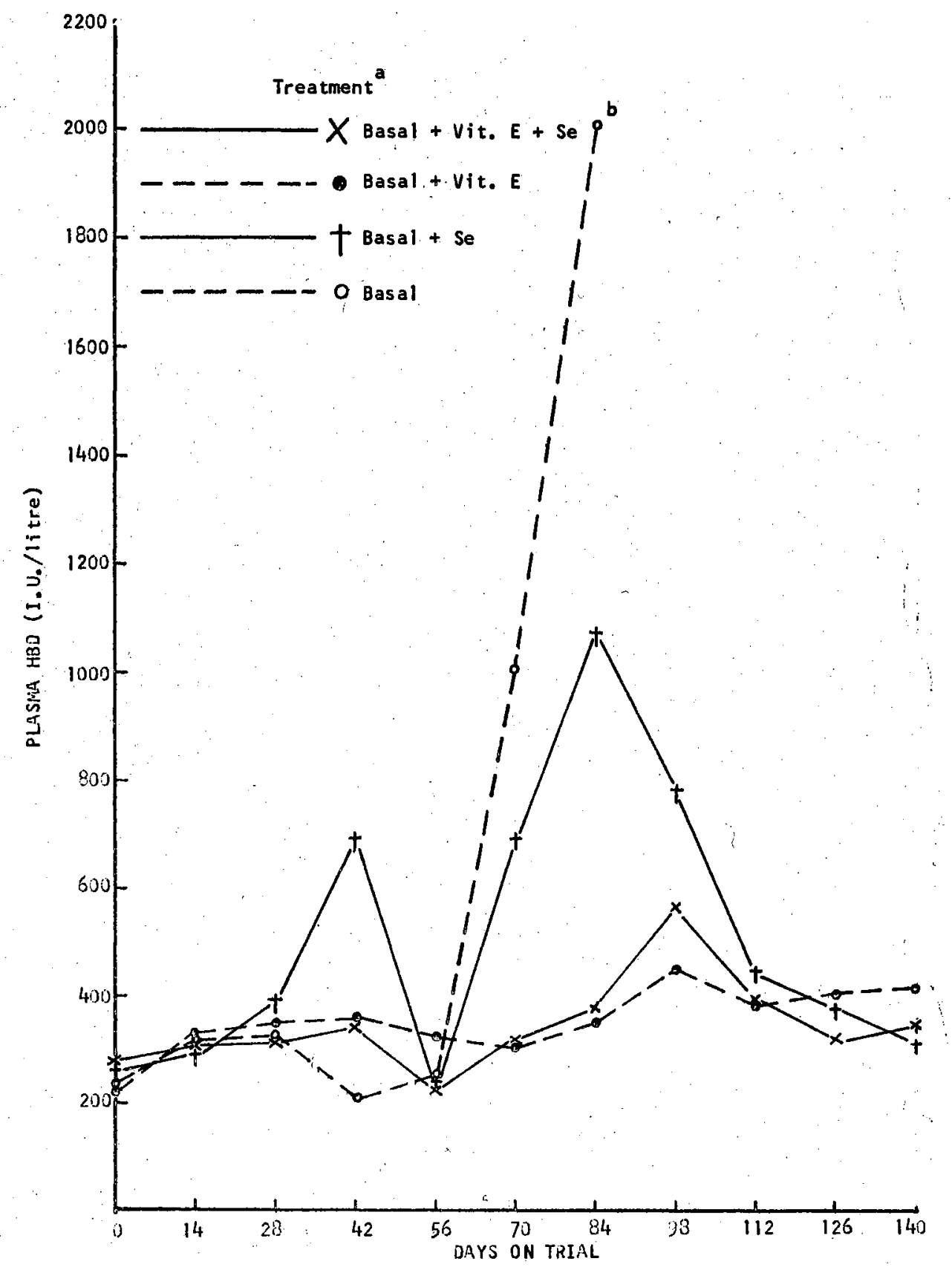

Figure 9. The Effect of Vitamin $E$ and Selenium on the Activity of Alpha-Hydroxy Butyric Acid Dehydrogenase in Blood Plasma of the Rams (astandard errors of treatment means (each point represents a mean of three observations) are in the Appendix (Table XXXIII). Bams which were on the basal treatment died.) 


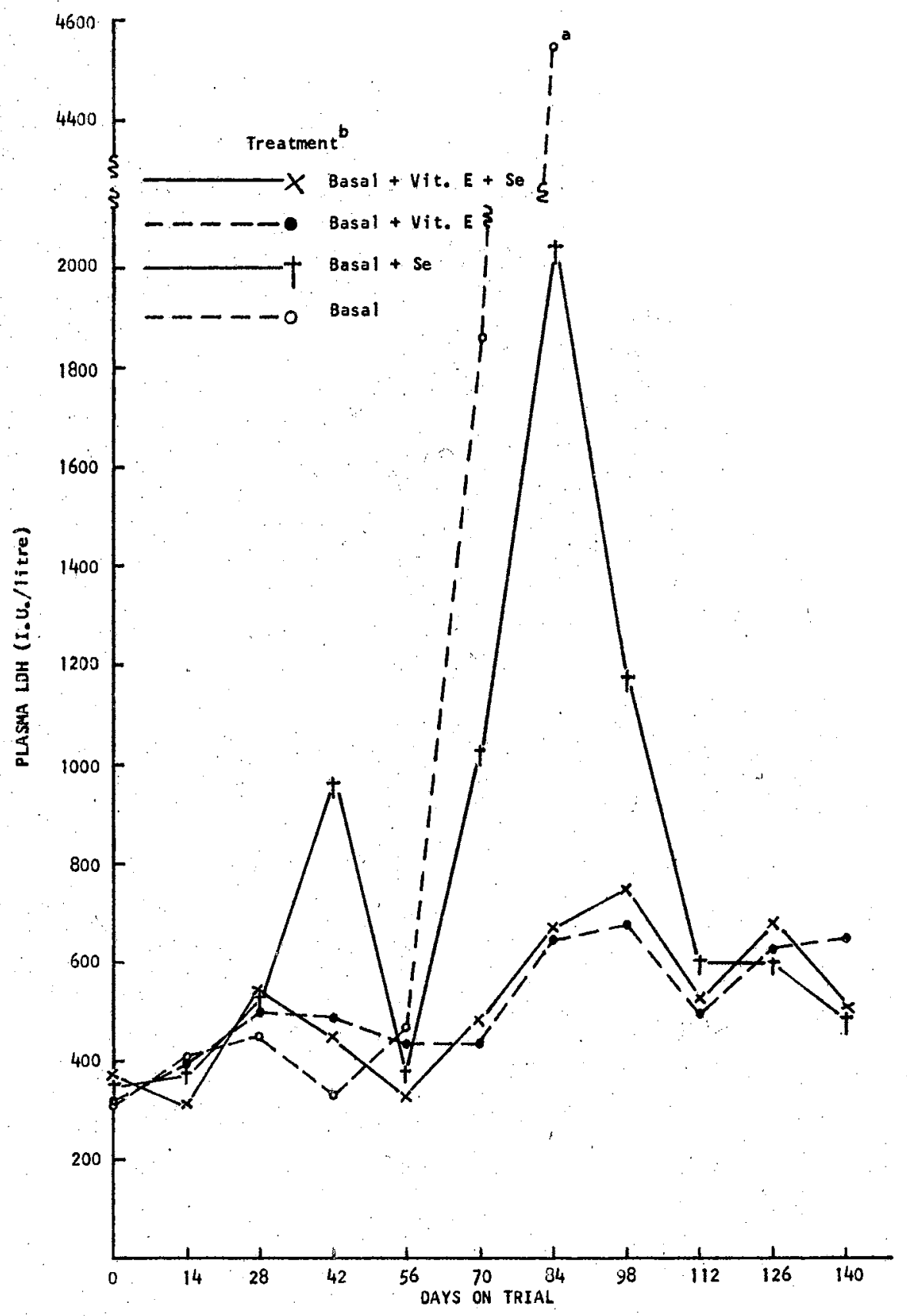

Figure 10. The Effect of Vitamin $E$ and Selenium on the Activity of Lactic Acid Dehydrogenase in Blood P lasma of the Rams. ( ${ }^{\text {a }}$ Standard errors of treatment means (each point represents a mean of three observations) are in the Appendix (Table XXXIV).

$b_{\text {Rams which were on the basal }}$ treatment died.) 
TABLE IX

THE EFFECT OF VITAMIN E AND SELENIUM ON THE ACTIVITIES OF SOME ENZYMES IN BLOOD PLASMA OF THE RAMS

\begin{tabular}{|c|c|c|c|c|c|}
\hline \multirow[b]{2}{*}{ I tem } & \multicolumn{4}{|c|}{ Treatment } & \multirow[b]{2}{*}{$S E^{b}$} \\
\hline & $\begin{array}{l}\text { Days } \\
\text { on } \\
\text { Trial }\end{array}$ & $\begin{array}{c}\text { Basa } 1 \\
+ \\
\text { Se }\end{array}$ & $\begin{array}{l}\text { Basal } \\
+ \\
\text { Vit. E }\end{array}$ & $\begin{array}{c}\text { Basal } \\
+ \\
\text { Vit. E } \\
+ \\
\text { Se }\end{array}$ & \\
\hline Number of rams & & 3 & 3 & 3 & \\
\hline Activity, I. U. $/ 1$. & & & & & \\
\hline $\begin{array}{l}\text { Glutamate- } \\
\text { Pyruvate } \\
\text { Transaminase }\end{array}$ & $\begin{array}{r}98 \\
112 \\
126 \\
146\end{array}$ & $\begin{array}{l}24.5^{c} \\
20.4^{c} \\
19.7 \\
13.8\end{array}$ & $\begin{array}{c}12.3^{d} \\
9.3^{d} \\
11.7^{-1} \\
30.0\end{array}$ & $\begin{array}{l}10.2^{d} \\
15.3^{d} \\
14.1 \\
12.0\end{array}$ & $\begin{array}{l}2.9 \\
3.7 \\
3.9 \\
5.7\end{array}$ \\
\hline $\begin{array}{l}\text { Glutamate } \\
\text { Dehydrogenase }\end{array}$ & $\begin{array}{r}98 \\
112 \\
126 \\
140\end{array}$ & $\begin{array}{l}16.8 \\
25.2 \\
19.6 \\
15.3^{e}\end{array}$ & $\begin{array}{l}17.6 \\
10.1 \\
31.9 \\
33.5^{f}\end{array}$ & $\begin{array}{r}17.1 \\
6.9 \\
15.4 \\
12.6^{e}\end{array}$ & $\begin{array}{r}4.6 \\
8.5 \\
10.7 \\
2.3\end{array}$ \\
\hline $\begin{array}{l}1,6 \text { Diphospho- } \\
\text { fructoaldolase }\end{array}$ & $\begin{array}{r}98 \\
112 \\
126 \\
140\end{array}$ & $\begin{array}{l}57.5 \\
34.5 \\
98.7^{c} \\
59.2^{c}\end{array}$ & $\begin{array}{l}24.2 \\
25.1^{d} \\
40.7^{d} d \\
47.7^{c, d}\end{array}$ & $\begin{array}{l}32.2 \\
26.5 \\
33.9^{d} \\
34.9^{d}\end{array}$ & $\begin{array}{r}10.0 \\
3.1 \\
10.8 \\
5.9\end{array}$ \\
\hline $\begin{array}{l}\text { 1, Phospho- } \\
\text { fruc toaldolase }\end{array}$ & $\begin{array}{l}112 \\
126\end{array}$ & $\begin{array}{r}15.2 \\
6.9\end{array}$ & $\begin{array}{l}16.0 \\
11.7\end{array}$ & $\begin{array}{l}16.7 \\
12.0\end{array}$ & $\begin{array}{l}2.1 \\
1.9\end{array}$ \\
\hline $\begin{array}{l}\text { Isocitrate } \\
\text { Dehydrogenase }\end{array}$ & $\begin{array}{l}126 \\
140\end{array}$ & $\begin{array}{l}7.7 \\
1.8\end{array}$ & $\begin{array}{l}7.0 \\
4.1\end{array}$ & $\begin{array}{l}4.8 \\
7.3\end{array}$ & $\begin{array}{l}1.3 \\
2.4\end{array}$ \\
\hline $\begin{array}{l}\text { Ornithine } \\
\text { Transcarbamylase }\end{array}$ & $\begin{array}{l}112 \\
126\end{array}$ & $\begin{array}{l}0.36 \\
0.24\end{array}$ & $\begin{array}{l}0.38 \\
0.25\end{array}$ & $\begin{array}{l}0.32 \\
0.23\end{array}$ & $\begin{array}{l}0.01 \\
0.01\end{array}$ \\
\hline
\end{tabular}

a Rams who were on the basal treatment died.

bstandard error of the treatment means.

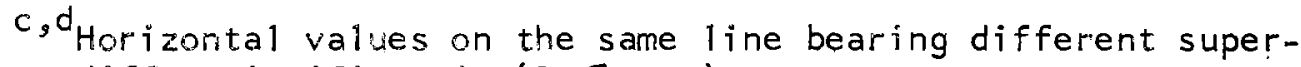
scripts differ significantly $(P<.05)$.

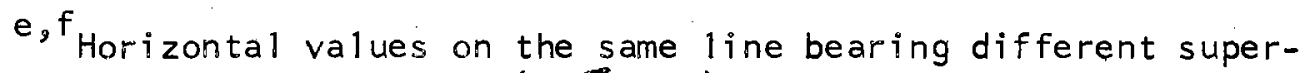
scripts differ significantly $(P<.01)$. 
TABLE $X$

THE EFFECT OF VITAMIN E AND SELENIUM ON THE RATIO OF THE

ACTIVITY OF ALPHA-HYDROXY BUTYRATE DEHYDROGENASE (HBD)

TO THE ACTIVITY OF LACTATE DEHYDROGENASE (LDH) IN

BLOOD PLASMA OF THE RAMS

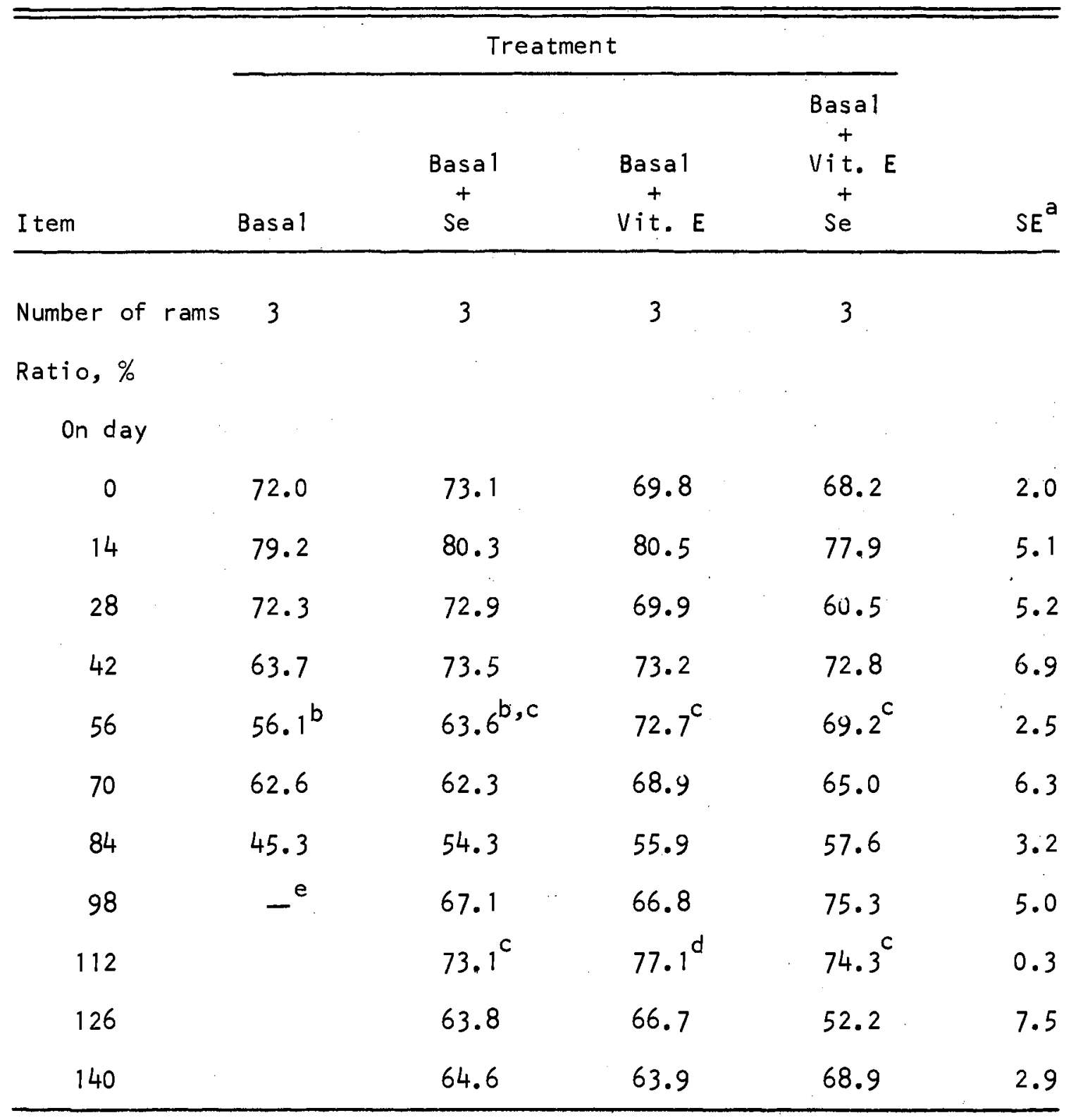

a Standard error of the treatment means.

b-d Horizontal values on the same line with different superscripts differ significantly $(P<.01)$.

Rams who were on the basal treatment died. 
deficiency in young 1 ambs and has attributed this to transient periods of necrosis in GDH-rich hepatic tissue. This was not observed in the present experiments.

Selenium was without effect upon plasma enzyme levels $(P>.05)$; a similar observation has been made by others (Wright and Be11, 1964; Hopkins et al., 1964). As all diets contained ethoxyquin, it is apparent that it was also without effect upon this phenomenon, which is contrary to the findings in young lambs made by Kuttler and Marble (1959) and Erwin et al. (1961). However, Erwin et al. (1961) applied a higher level of ethoxyquin ( 0.1 percent versus 0.0125 percent) in the diets used in their experiments.

Elevation of plasma enzymes in both trials occurred at an early stage; for example, GOT was elevated $(P<.05)$ after only 28 days in the ewes. Although all enzymes appeared elevated after 42 days of Trial 2, this difference was not significant $(P>.05)$; the elevation occurred in only one animal. Thus in Trial 2, the elevation of plasma enzymes was only significant after 70 days $(G 0 T, P<.05)$ and agrees with the findings of Wright and Bell (1964). If very young sheep are used, this response to vitamin E-deficiency occurs much earlier (Boyd, 1968).

In both of these trials, it was found that the elevation of plasma enzymes occurred first among those vitamin E-deficient animals receiving selenium and is contrary to the findings of Wright and Bell (1964) and Hopkins et al., (1964), who found that selenium delayed an increase in plasma GOT in vitamin E deficiency.

Evaluation of data collected on individual sheep revealed a tendency for elevated enzyme levels in plasma to be transient. The fact 
that the resultant peaks in plasma enzyme levels did not coincide among different sheep on the same treatment and also that the peaks were of different duration in different animals is largely responsible for the extensive variation in these data. The variation is not due to analytical error, which was found to be low. The transiency in plasma enzyme levels was not so pronounced in vitamin E-deficient animals not receiving selenium. In only two of the six ewes on this treatment in Trial 1, did values return to nomal before death. In Trial 2, all the sheep on this treatment died once the plasma enzyme levels became elevated. These results considered alongside those of animal survival indicate that selenium could temporarily satisfy some of the demands of the vitamin E-deficient animal. It is important to note that as a result of the transient nature of elevated enzyme levels, a normal value of an enzyme in plasma does not by itself confirm adequate vitamin $E$ status.

To test the effect of vitamin $E$ on restoration of plasma enzyme levels to normal, blood was sampled from the three ewes on the basal ration in Trial 1, seven days after vitamin $E$ was administered. The GOT level found was similar to that in ewes treated with vitamin $E$ and selenium. This experiment was repeated in two wethers which were vitamin $E$ deficient and the results are shown in Figure 11 . The level of GOT in plasma was reduced rapidly; the half-time for disappearance of the enzyme being 1.6 to 2.1 days.

The phenomenon of elevated enzyme levels is worthy of some discussion since $i t$ is an early response to the condition of vitamin Edeficiency. Blincoe and Marble (1960) obtained a correlation of 0.97 between LDH and GOT in plasma of sheep wi th muscular dystrophy, the 


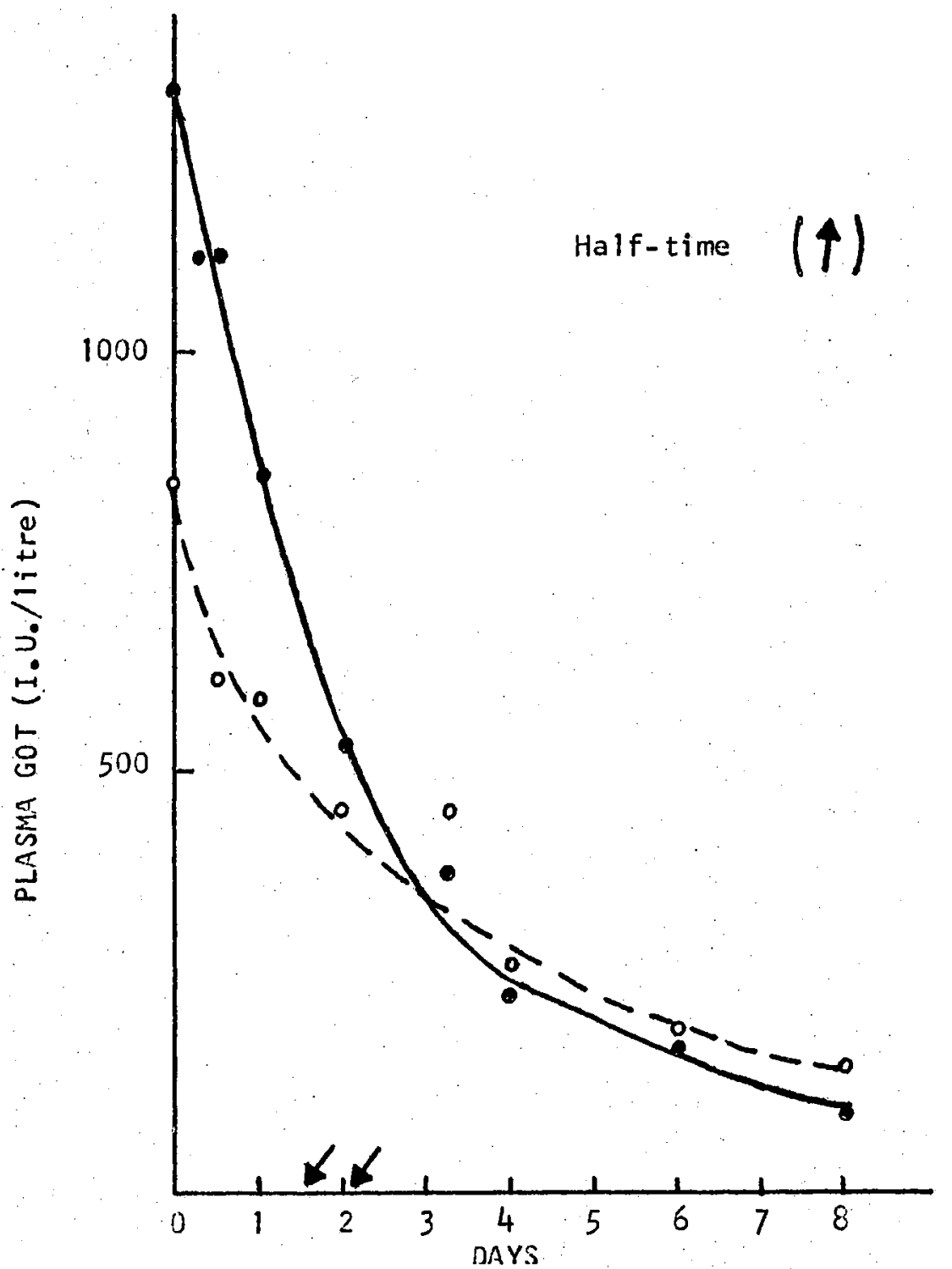

Figure 11. The Effect of Vitamin E Treatment on the Activity of Plasma Glutamate-0xaloacetate Transaminase in Vitamin E-Deficient Sheep. (Two vitamin E-deficient wethers were injected with 700 I.U. Vitamin $E$ at Day 0 ). 
corresponding correlation for this trial is 0.70 . The correlation coefficient between GOT and CPK is 0.45 . The following are factors which may be responsible for an inconsistent relationship between the activities of one enzyme to another. First, the activity of an enzyme may not be constant throughout the muscular system. Secondly, plasma enzymes may be removed from the circulatory system at different rates. Boyd (1967) demonstrated that the LDH isoenzyme which predominates in skeletal muscle is removed from plasma at a greater rate than the heart isoenzyme. Third, varying proportions of different tissues may be affected by $v i t a m i n E$ at different stages of deficiency.

Undoubtedly, necrotic tissue is the major source of plasma enzymes. However, it might be an oversimplification to ascribe this as the only mechanism resulting in the phenomenon (Henley et al., 1966). In a review on plasma enzymes, Hess (1963) states many conditions which cause an increase in cell permeability with consequent leakage of enzymes into the extracellular space. A fundamental cause is an oxygen deficiency and a reduction in ATP. It is possible therefore that vitamin E may have a role at some subcellular site which is directly responsible for maintaining the ce11 membrane. There is a need to evaluate whether or not elevated plasma enzyme levels in vitamin E deficiency precede the appearance of any necrotic tissue.

There are few reports available in the $1 \mathrm{i}$ terature on standard plasma enzyme levels in sheep. Thus the values obtained in these experiments for sheep treated with vitamin $E$ and selenium have been collected together and are given in the Appendix (Table XXVIII)。 


\section{Relative Weight of Organs}

Vitamin E deficiency resulted in an increase in the relative weight of liver $(P<.05)$ and kidneys (Table XI). This observation is most pronounced for those animals which died from the vitamin E deficiency, in which the average relative liver, heart and kidney weights were $17.9,4.8$ and $3.4 \mathrm{gm} \cdot / \mathrm{kg}$, , respectively. The increase in relative organ weight could be a result either of enlargement of the organ itself or a reduction in peripheral body tissues. It would appear that it is a result of enlargement of the organ itself, because there were no significant differences in body weight among the animals. Thus, the effect of different treatments used in this trial upon activities of enzymes and concentrations of vitamins in the tissues is expressed both on a per gram and a per organ basis.

\section{Lysosomal Enzymes in Tissues}

Vitamin E deficiency affects the activities of lysosomal enzymes in tissues of many animals. There appears to be only one report on sheep and this was on muscle (Desai, 1966). The values obtained for protease activities in liver are shown in Table XII. Total liver protease was greater $(P<.05)$ in vitamin E-treated ewes than in seleniumand vi tamin E-treated ewes. There were no differences $(P>.05)$ between treatments regarding the proportion of the total enzyme activity which could be associated with the different subcellular fractions. The total proteolytic activity of sheep liver appears to be greater than in chicken (Thayer and Nelson, 1968) and rat liver (Dingle et al., 1966; Bunyan et al., 1967c). Muscle necrosis is the outstanding lesion in the vitamin E-deficient sheep or rabbit. Proteolytic activity in liver of 
TABLE XI

THE EFFECT OF VITAMIN E AND SELENIUM ON THE RELATIVE WEIGHTS OF LIVER, HEART AND KIDNEYS IN THE EWES ${ }^{a}$

\begin{tabular}{|c|c|c|c|c|}
\hline \multirow[b]{2}{*}{ I tem } & \multicolumn{3}{|c|}{ Treatment } & \multirow[b]{2}{*}{$\mathrm{SE}^{\mathrm{b}}$} \\
\hline & $\begin{array}{c}\text { Basal } \\
+ \\
\mathrm{Se}\end{array}$ & $\begin{array}{c}\text { Basal } \\
+ \\
\text { Vit. E }\end{array}$ & $\begin{array}{c}\text { Basal } \\
+ \\
\text { Vit. E } \\
+ \\
\text { Se }\end{array}$ & \\
\hline & & & & \\
\hline Number of animals & 6 & 6 & 6 & \\
\hline Live weight, $\mathrm{kg}$. & 55.2 & 48.8 & 53.0 & 3.21 \\
\hline Liver, gm./kg. live wt. & $12.0^{c}$ & $11.3^{c, d}$ & $9.7^{d}$ & 0.65 \\
\hline Heart, gm. $/ \mathrm{kg}$. live $w t_{0}$ & 3.8 & 3.6 & 3.7 & 0.20 \\
\hline Kidneys, gm。 $/ \mathrm{kg}$. live wt. & 2.0 & 2.0 & 1.6 & 0.15 \\
\hline
\end{tabular}

$a_{\text {Ewes }}$ who were on the basal treatment died.

${ }^{b}$ Standard error of the treatment means.

$c, d$ Horizontal values on the same line bearing different superscripts differ significantly $(P<.05)$. 
TABLE XII

THE EFFECT OF VITAMIN E AND SELENIUM ON THE TOTAL ACTIVITY, SPECIFIC ACTIVITY AND SUBCELLULAR DISTRIBUTION OF ACID

PROTEASE IN LIVER OF THE EWES ${ }^{a}$

\begin{tabular}{|c|c|c|c|c|}
\hline \multirow[b]{2}{*}{ I tem } & \multicolumn{3}{|c|}{ Treatment } & \multirow[b]{2}{*}{$S E^{b}$} \\
\hline & $\begin{array}{c}\text { Basal } \\
+ \\
\mathrm{Se}\end{array}$ & $\begin{array}{c}\text { Basal } \\
+ \\
\text { Vit. } E\end{array}$ & $\begin{array}{c}\text { Basal } \\
+ \\
\text { Vit. E } \\
+ \\
\text { Se }\end{array}$ & \\
\hline Number of animals & 6 & 6 & 6 & \\
\hline \multicolumn{5}{|l|}{ Total activity } \\
\hline $\begin{array}{l}\text { Units/mg. liver } \\
\text { Units/liver/gm. live wt. }\end{array}$ & $\begin{array}{l}17.7 \\
215.5\end{array}$ & $\begin{array}{l}24.6 \\
273.8^{e}\end{array}$ & $\begin{array}{l}17.7 \\
166.9^{d}\end{array}$ & $\begin{array}{l}2.87 \\
30.2\end{array}$ \\
\hline \multicolumn{5}{|l|}{ Specific activity } \\
\hline Units/mg. soluble protein ${ }^{c}$ & 16.5 & $22: 2$ & 15.2 & 3.44 \\
\hline \multicolumn{5}{|l|}{ Nuclear fractionc } \\
\hline $\begin{array}{l}\text { Units/mg. liver } \\
\% \text { of total activity }\end{array}$ & $\begin{array}{r}7.8 \\
46.3\end{array}$ & $\begin{array}{l}10.1 \\
41.6\end{array}$ & $\begin{array}{r}8.0 \\
43.0\end{array}$ & $\begin{array}{l}1.46 \\
4.49\end{array}$ \\
\hline Lysosomal fraction & . & & & \\
\hline $\begin{array}{l}\text { Units/mg. liver }{ }^{\mathrm{c}} \\
\% \text { of total activity }\end{array}$ & $\begin{array}{r}6.5 \\
38.5\end{array}$ & $\begin{array}{r}9.3 \\
37.7\end{array}$ & $\begin{array}{r}6.6 \\
39.0\end{array}$ & $\begin{array}{l}1.08 \\
3.97\end{array}$ \\
\hline Supernatant fraction $c$ & & & & \\
\hline $\begin{array}{l}\text { Units/mg. liver } \\
\% \text { of total activity }\end{array}$ & $\begin{array}{r}3.3 \\
15.2\end{array}$ & $\begin{array}{r}5.3 \\
20.7\end{array}$ & $\begin{array}{r}3.1 \\
18.0\end{array}$ & $\begin{array}{l}1.11 \\
3.91\end{array}$ \\
\hline
\end{tabular}

${ }^{a}$ Ewes who were on the basal treatment died.

${ }^{b}$ Standard error of the treatment means.

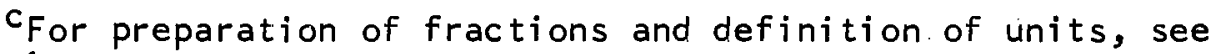
page 26.

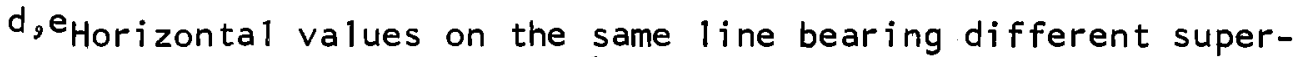
scripts differ significantly $(P<.05)$. 
rabbits fed vitamin E-deficient diets was increased two-fold compared to the controls (Zalkin et al., 1962). Results of the present experiment indicate that this is not true for sheep.

Figure 12 illustrates the effect of treatment upon stability of the liver lysosomes. It was found that greater proportions of protease were released from liver lysosomes taken from the vitamin E-treated ewes than the others. As slopes of the lines are similar, the differences appear to be a result of greater lability from the origin of the incubation rather than a greater rate of release. In vitamin Etreated ewes, it was found that a slightly greater proportion of subcellular liver protease was present in the supernatant fraction (Table $X I I)$.

The proportion of enzyme released after a two hour incubation of the lysosomes agrees with results obtained from chicken liver (Thayer and Nelson, 1968) and rat kidney (Moore et al., 1967).

The finding that vitamin $E$ deficiency results in greater total activity for skeletal muscle protease and beta-glucuronidase (Table XIII) supports the results of Desai (1966), who used young lambs. Total activities of protease and betamglucuronidase were 10.5- and 8.5-fold greater, respectively, for selenium- compared to vitamin Eand selenium-treated ewes. In two ewes, which were sampled in the terminal stages of vitamin E deficiency, total skeletal muscle protease and beta-glucuronidase activity were elevated 82- and 19-fold, respectively, which indicate the activities of the enzymes are greatly increased at this time.

Protease, as free enzyme, was found in only one vitamin Edeficient ewe. A greater proportion of the total beta-glucuronidase 


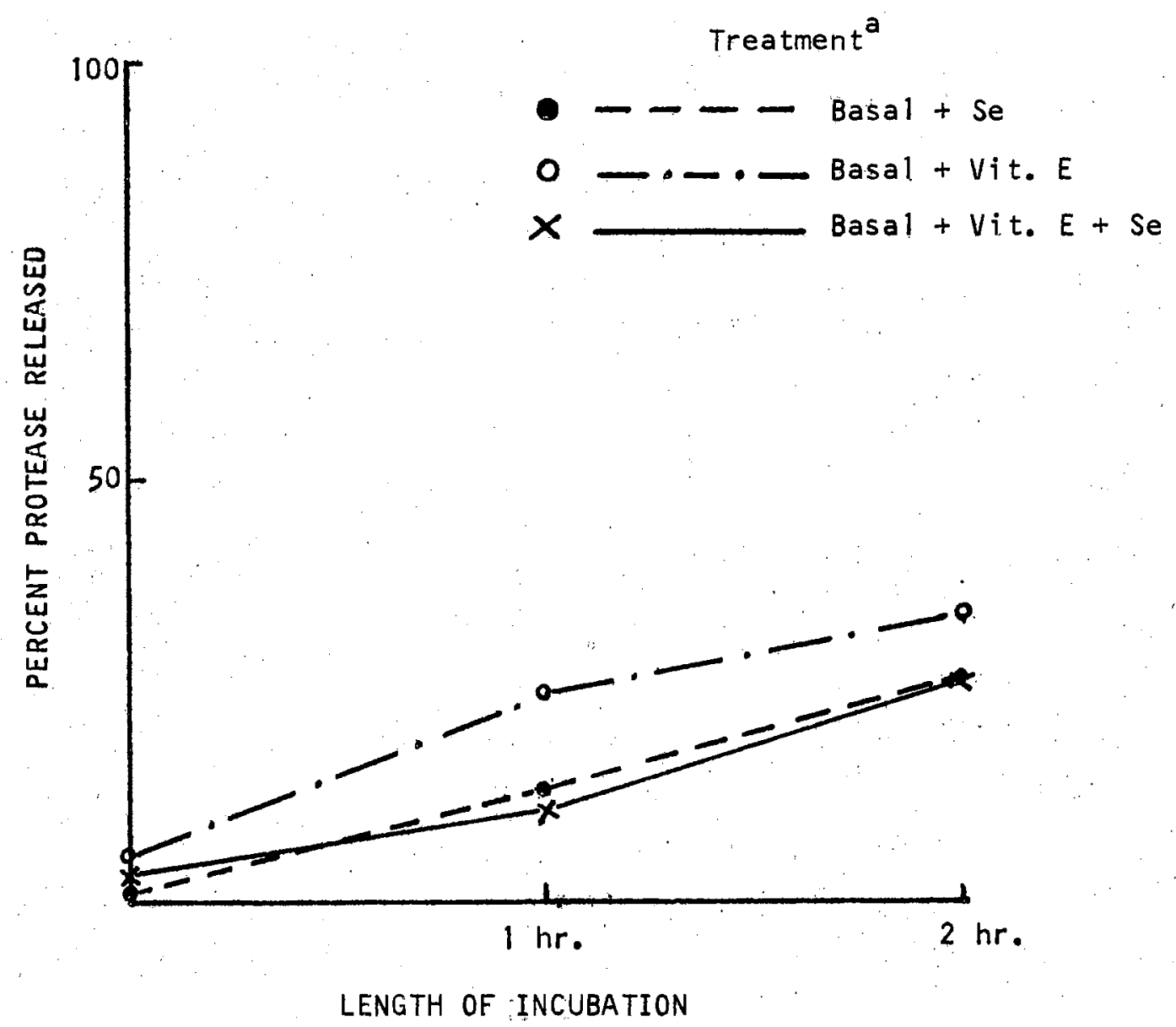

Figure 12. The Effect of Vitamin $E$ and Selenium on the Stability of Liver Lysosomes as Measured by the Release of Acid Protease (For experimental technique, see page 26. aEach point is the mean of six observations and the standard error of the combined means of eighteen observations per treatment is $2.6 \%$ ) 
TABLE XIII

THE EFFECT OF VITAMIN E AND SELENIUM ON THE TOTAL AND FREE

ACTIVITY OF ACID PROTEASE AND BETA-GLUCURONIDASE IN

SKELETAL MUSCLE OF THE EWES ${ }^{a}$

\begin{tabular}{|c|c|c|c|c|}
\hline \multirow[b]{2}{*}{ I tem } & \multicolumn{3}{|c|}{ Treatment } & \multirow[b]{2}{*}{$S E^{b}$} \\
\hline & $\begin{array}{c}\text { Basa } 1 \\
+ \\
\mathrm{Se}\end{array}$ & $\begin{array}{c}\text { Basal } \\
+ \\
\text { Vit. E }\end{array}$ & $\begin{array}{c}\text { Basal } \\
+ \\
\text { vit. E } \\
+ \\
\text { Se }\end{array}$ & \\
\hline \multicolumn{5}{|l|}{ Acid protease } \\
\hline Number of animals & 6 & 6 & 6 & \\
\hline Total activity, units/mg. ${ }^{c}$ & $0.443^{d}$ & $0.046^{\mathrm{e}}$ & $0.042^{e}$ & 0.091 \\
\hline Free activity, units/mg. ${ }^{c}$ & 0.022 & ND & ND & 0.013 \\
\hline $\begin{array}{l}\text { Free activity, } \\
\% \text { of total activity }\end{array}$ & 2.0 & & & 1.2 \\
\hline \multicolumn{5}{|l|}{ Beta-Glucuronidase } \\
\hline Number of animals & 5 & 4 & 5 & \\
\hline Total activity, $m-I_{0} U_{0} / g m$. & $4.34^{d}$ & $1.06^{\mathrm{e}}$ & $0.51^{\mathrm{e}}$ & 0.315 \\
\hline Free activity, m-I. $U_{0} / g m_{0}{ }^{c}$ & $1.87^{d}$ & $0.18^{e}$ & $0.15^{\mathrm{e}}$ & 0.373 \\
\hline $\begin{array}{l}\text { Free activity, } \\
\% \text { of total activity }\end{array}$ & 44.5 & 11.2 & 12.6 & 13.3 \\
\hline
\end{tabular}

${ }^{a}$ Ewes who were on the basal treatment died.

${ }^{b}$ Standard error of the treatment mean(s).

CFor determination of free activity and definition of acid protease units, see page 26.

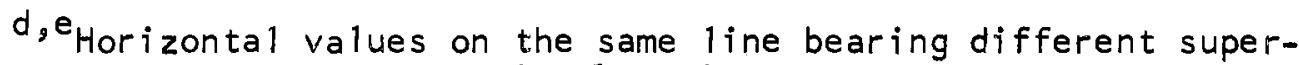
scripts differ significantly $(P<.01)$.

ND, None detectable. 
activity was free, indicating a difference in the subcellular localization of these two enzymes in sheep skeletal muscle. Nevertheless, it is clear that the amount of lysosomal bound enzyme was increased significantly in vitamin E-deficiency. The proportion of free lysosomal enzyme activity was not determined by Desai (1966). In work on muscle 1ysosomes from vitamin E-sufficient and -deficient rabbits, a variation among enzymes in the proportion of free enzyme was also found (Zalkin et a1., 1962). Contrary to results reported here, these workers showed that 87 percent of the protease activity from vitamin E-deficient rabbit muscle was free, thus indicating a species difference.

Results of the present experiment indicate that the hydrolytic enzymes of sheep muscle are structure linked. Activities of hydrolytic enzymes in normal sheep muscle are extremely low; this is in agreement with results obtained on the rabbit (Zalkin et al., 1962). It appears that the species, which exhibit muscle lesions in vitamin $E$ deficiency, simultaneously exhibit increases in lysosomal enzyme activities (Zalkin et a1. , 1962; Desai, 1966; Bunyan et a1., 1967a ; Koszalki èt al.; 1961).

Owing to the subjective nature of evaluating the extent of muscle necrosis in these sheep, it appears impossible to ascribe a relationship between the extent of necrosis and the elevation of lysosomal enzymes. Severe muscle necrosis and greatly elevated enzyme levels existed in the skeletal muscle of two animals which were in terminal stages of the vitamin E-deficiency syndrome.

Due to the involvement of 1 ysosomal enzymes in vitamin E-deficient muscle, it was decided to analyse uterine and placental tissue for the same enzymes. However, no differences $(P>.05)$ were found in the 
activities of beta-glucuronidase and protease in the uteri and placentae from sheep (Table XIV). The activities of both enzymes were greater in the uterus and placenta than in skeletal muscle. Also, a consistently higher proportion of both of these enzymes were in the free form as compared to muscle。

In work on lysosomal enzymes in rat uterus, no differences could be attributed to vitamin E deficiency except three days after fetal resorption had taken place, at which time beta-glucuronidase increased (Bunyan et al., 1967b). These results indicate that the increase in activity was a requirement for involution of the uterus. Results in the present experiment support the hypothesis (Figure 13). A general increase in activities of lysosomal enzymes of uterus and placenta was observed toward the end of pregnancy.

The results of the present experiments indicate that vitamin $E$ deficiency affects only the activity of the lysosomal enzymes in skeletal muscle, the tissue which is pathologically most severely affected. There was a relationship between selenium deficiency and the activity of protease in sheep liver but its significance is not clear; there were no obvious pathological lesions of this tissue associated.

\section{Creatine Phosphokinase in Tissues}

Elevated levels of several enzymes were found in blood plasma of vitamin E-deficient sheep. If this phenomenon is a consequence of tissue necrosis, then necrotic tissue should contain depressed quantities of the same enzymes. There were no significant differences $(P>.05)$ in activity of CPK in any one tissue but values were lowest in skeletal muscle, heart and uterus and placenta of the vitamin E-deficient animals 
TABLE XIV

THE EFFECT OF VITAMIN E AND SELENIUM ON THE TOTAL AND FREE

ACTIVITY OF ACID PROTEASE AND BETA-GLUCURONIDASE IN UTERUS AND PLACENTA OF THE EWES ${ }^{\mathrm{a}}$

\begin{tabular}{|c|c|c|c|c|}
\hline \multirow[b]{2}{*}{ I tem } & \multicolumn{3}{|c|}{ Treatment } & \multirow[b]{2}{*}{$S E^{b}$} \\
\hline & $\begin{array}{c}\text { Basa } 1 \\
+ \\
\mathrm{Se}\end{array}$ & $\begin{array}{c}\text { Basal } \\
+ \\
\text { Vit. } E\end{array}$ & $\begin{array}{l}\text { Basal } \\
+ \\
\text { Vit. E } \\
+ \\
\text { Se }\end{array}$ & \\
\hline \multicolumn{5}{|l|}{ Acid protease } \\
\hline Number of animals & 6 & 6 & 6 & \\
\hline Total activity, units/mgo. & 9.0 & 10.7 & 5.2 & 3.30 \\
\hline $\begin{array}{l}\text { Free activity }{ }^{\mathrm{c}} \text {, units/mg. } \\
\text { Free activity }{ }^{\mathrm{c}} \\
\% \text { of total activity }\end{array}$ & 64.9 & 65.4 & 73.6 & 11.7 \\
\hline \multicolumn{5}{|l|}{ Beta-glucuronidase } \\
\hline Number of animals & 5 & 4 & 5 & \\
\hline Total activity, $m_{\infty} I_{0} U_{0} / g m_{0}$ & 22.6 & 17.8 & 15.1 & 5.93 \\
\hline Free activity ${ }^{\mathrm{C}}, \mathrm{m}_{\mathrm{a}} I_{0} U_{0} / \mathrm{gm}_{0}$ & 15.4 & 11.6 & 7.3 & 3.44 \\
\hline $\begin{array}{l}\text { Free activity }{ }^{\mathrm{C}} \\
\quad \% \text { of total activity }\end{array}$ & 67.1 & 73.0 & 62.7 & 15.2 \\
\hline
\end{tabular}

${ }^{a}$ Ewes who were on the basal treatment died.

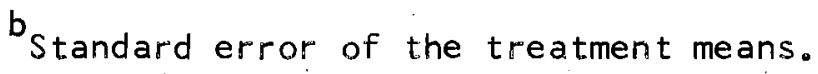

${ }^{\mathrm{c}}$ For determination of free activity and definition of acid protease units, see page 26 . 


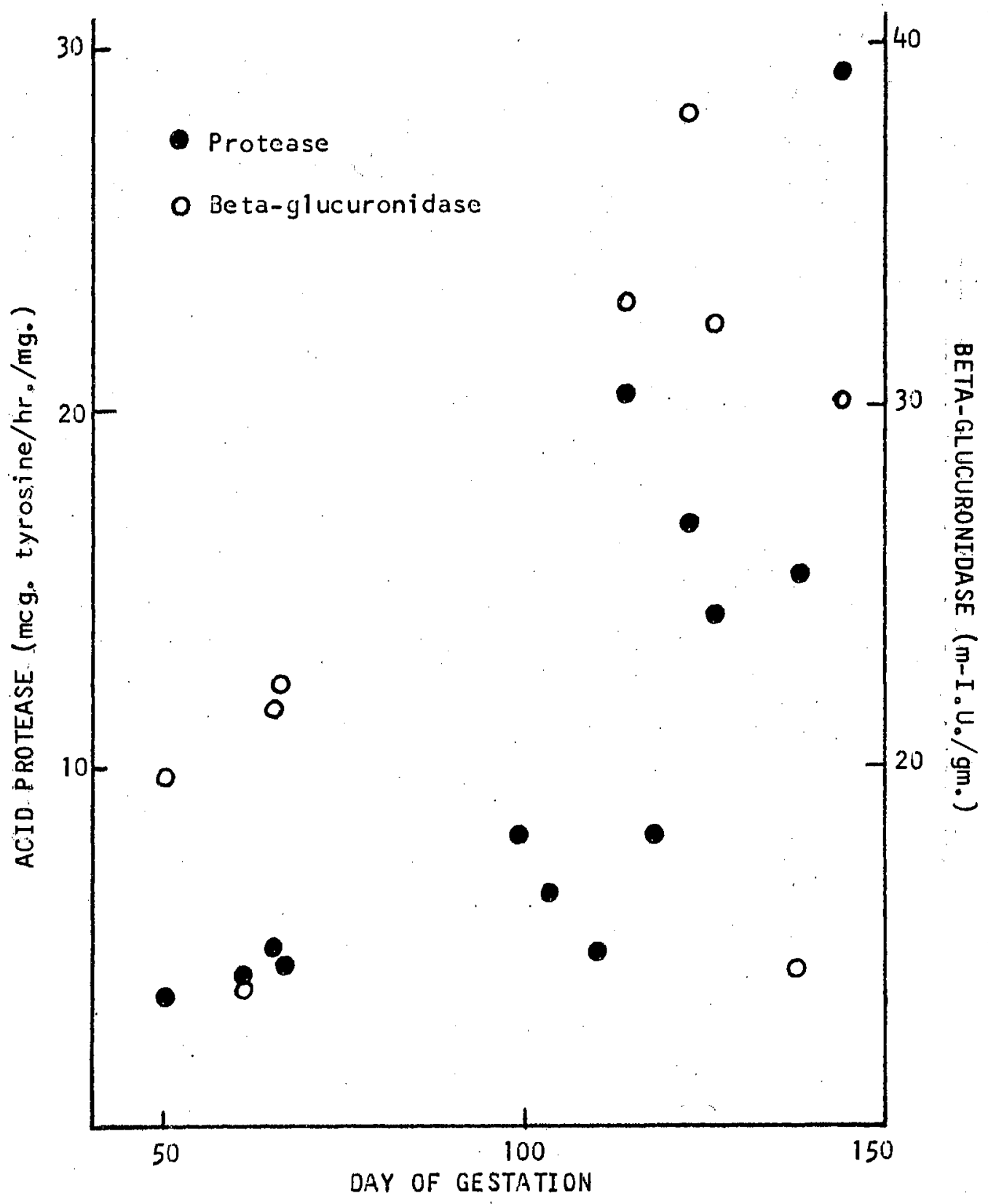

Figure 13. The Effect of Day of Gestation on the Activities of Acid Protease and BetaGlucuronidase in the Uterus and Placenta of the Pregnant Ewes. (Each point represents one observation. Mean values determined for nonpregnant ewes: Acid protease - 1.1 mcgotyrosine/hro/mg.; Beta-Glucuronidase - $6.9 \mathrm{~m}-\mathrm{I}_{0} \mathrm{U}_{0} / \mathrm{gm}$.) 
(Table XV). Upon storage, detergent depressed activity of CPK, thus results presented are those obtained from homogenates wi thout the inclusion of the detergent. Depression in skeletal muscle CPK activity was most striking in samples obtained from two animals, which were dying from vitamin E deficiency. The mean skeletal muscle CPK activity for these animals was determined to be $119.6 \mathrm{I} . \mathrm{U} . / \mathrm{gm}$. On the contrary, the activity of C.PK in the hearts of the same animals was increased to a mean value of 388 I.U. per heart per $\mathrm{kg}$. live wt. Elevated activity of CPK in plasma was associated wi th depressed activity of CPK in muscle. Activities of CPK in skeletal muscle and heart of sheep fetuses were below that obtained in adult animals but there were no differences $(P>.05)$ between treatments. Values determined for muscle in the control adults of this experiment agree closely with values obtained in the horse (Cardinet et al. 1967).

\section{Lactate Dehydrogenase and A1pha-Hydroxy}

Butyrate Dehydrogenase in Tissues

LDH is another prominent enzyme found in the soluble portion of the cel1. As mentioned previously, at least three and maybe four of the five isoenzymes of $\mathrm{LDH}$ are not only active on the natural substrate of the enzyme, lactic acid, but also on alpha-hydroxy butyric acid. Different isoenzymes of $L D H$ are present in different tissues of the sheep (Boyd, 1964). Thus changes in the proportion of activity, HBD/ $L D H$, reflect changes in the composition of $L D H$ in the different tissues. Activities of $H B D$ and $L D H$ in skeletal muscle were lowest in vitamin $E_{r}$ and selenium-treated ewes but the difference was not significant $(P>.05)($ Table XVI)。 However, in one ewe, sampled in the terminal stage of the vitamin Edeficjency disease, the HBD and $L D H$ values in 
TABLE XV

THE EFFECT OF VITAMIN E AND SELENIUM ON THE ACTIVITY OF CREATINE PHOSPHOKINASE IN SKEI.ETAL MUSCLE, HEART AND UTERUS AND PLACENTA OF THE EWES

\begin{tabular}{|c|c|c|c|c|}
\hline \multirow[b]{2}{*}{ I tem } & \multicolumn{3}{|c|}{ Treatment } & \multirow[b]{2}{*}{$S E^{b}$} \\
\hline & $\begin{array}{c}\text { Basal } \\
+ \\
\text { Se }\end{array}$ & $\begin{array}{c}\text { Basal } \\
+ \\
\text { Vit. E }\end{array}$ & $\begin{array}{c}\text { Basal } \\
+ \\
\text { Vit. } \\
+ \\
\text { Se }\end{array}$ & \\
\hline Number of animals & 4 & 4 & 4 & \\
\hline Skeletal muscle, I. U./gm。 & 348.1 & 379.9 & 362.0 & 25.9 \\
\hline \multicolumn{5}{|l|}{ Heart } \\
\hline$I_{0} U_{0} / g m_{0}$ & 31.8 & 35.2 & 42.5 & 4.6 \\
\hline$I_{0} U_{0} /$ heart $/ \mathrm{kg}$. I ive $w t_{0}$ & 124.7 & 119.2 & 155.4 & 13.7 \\
\hline Uterus and placenta, Ioua/gm. & 5.3 & 8.2 & 6.2 & 1.2 \\
\hline
\end{tabular}

aEwes who were on the basal treatment died.

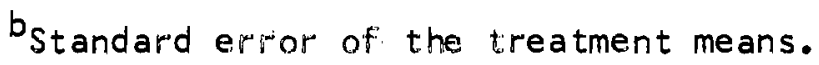


TABLE XVI

THE EFFECT OF VITAMIN E AND SELENIUM ON THE ACTIVITIES OF

ALPHA-HYDROXY BUTYRATE DEHYDROGENASE (HBD) AND LACTATE DEHYDROGENASE (LDH) IN SKELETAL MUSCLE, HEART AND UTERUS AND PLACENTA OF THE EWES ${ }^{a}$

\begin{tabular}{|c|c|c|c|c|}
\hline \multirow[b]{2}{*}{ I tem } & \multicolumn{3}{|c|}{ Treatment } & \multirow[b]{2}{*}{$S E^{b}$} \\
\hline & $\begin{array}{c}\text { Basal } \\
+ \\
\mathrm{Se}\end{array}$ & $\begin{array}{c}\text { Basal } \\
+ \\
\text { Vit. E }\end{array}$ & $\begin{array}{l}\text { Basal } \\
+ \\
\text { Vit. E } \\
+ \\
\text { Se }\end{array}$ & \\
\hline Number of animals & 4 & 4 & 4 & \\
\hline \multicolumn{5}{|l|}{ Skeletal muscle } \\
\hline $\begin{array}{l}\mathrm{HBD}, \mathrm{I}_{0} \mathrm{U}_{0} / \mathrm{gm} . \\
\mathrm{LDH}, \mathrm{I}_{0} \mathrm{U}_{0} / \mathrm{gm} . \\
\mathrm{HBD} / \mathrm{LDH}, \%\end{array}$ & $\begin{array}{r}119.6 \\
471.4 \\
25.3\end{array}$ & $\begin{array}{r}133.3 \\
547.7 \\
25.0\end{array}$ & $\begin{array}{r}105.5 \\
378.0 \\
28.7\end{array}$ & $\begin{array}{r}13.0 \\
69.8 \\
1.2\end{array}$ \\
\hline \multicolumn{5}{|l|}{ Heart } \\
\hline 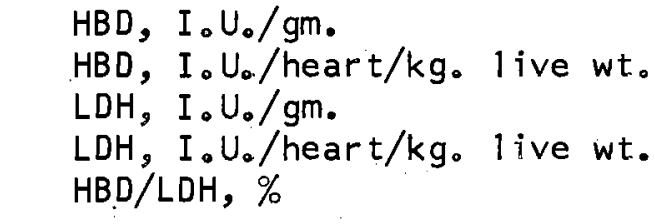 & $\begin{array}{l}95.0 \\
371.6^{c} \\
123.0 \\
480.4 \\
77.6\end{array}$ & $\begin{array}{l}83.8 \mathrm{~d} \\
283.2^{d} \\
113.0 \\
383.6 \\
74.6\end{array}$ & $\begin{array}{l}100.8 \\
375.6^{c} \\
130.9 \\
486.4 \\
77.2\end{array}$ & $\begin{array}{r}6.7 \\
25.1 \\
10.4 \\
38.5 \\
2.2\end{array}$ \\
\hline \multicolumn{5}{|l|}{ Uterus and placenta } \\
\hline $\begin{array}{l}\mathrm{HBD}, \mathrm{I}_{\circ} \mathrm{U}_{0} / \mathrm{gm}_{0} \\
\mathrm{LDH}, \mathrm{I}_{0} \mathrm{U}_{0} / \mathrm{gm}_{0} \\
\mathrm{HBD} / \mathrm{LDH}_{2} \%\end{array}$ & $\begin{array}{l}33.6 \\
68.2 \\
54.9\end{array}$ & $\begin{array}{l}39.4 \\
67.0 \\
57.7\end{array}$ & $\begin{array}{r}9.7 \\
16.0 \\
63.2\end{array}$ & $\begin{array}{r}19.9 \\
40.7 \\
7.5\end{array}$ \\
\hline
\end{tabular}

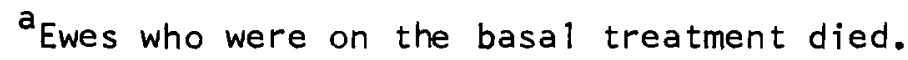

${ }^{b}$ standard error of the treatment means.

$c, d$ Horizontal values on the same line bearing different superscripts differ significantly $(P<.10)$. 
skeletal muscle were depressed to 49.9 and $98.4 \mathrm{I}_{\circ} \mathrm{U}_{0}$ per gmo, respectively. Total HBD and LDH per heart were significantly lower $(P<.10)$ in vitamin E-treated anima1s。

There were no treatment differences in the ratio of $\mathrm{HBD} / \mathrm{LDH}$, for skeletal muscle, heart or uterus and placenta. These results support the observations of Boyd (1964), who found that vitamin E deficiency did not affect the spread of LDH isoenzymes in lamb tissues. In contrast, the ratio of $\mathrm{HBD} / \mathrm{LDH}$ in the skeletal muscle of the sheep which died from vitamin E-deficiency, was increased to 50.7 percent and this result supports the observations of Paulson et al. (1966). Perhaps the severity of vitamin $E$ deficiency affects this phenomenon.

The work reported here on the ratio of $\mathrm{HBD} / \mathrm{LDH}$ indicates that there are major differences between sheep tissues, presumably reflecting a change in spread of the isoenzymes of LDH. Like LDH, HBD is simple to assay. This method should be explored as an alternative to the somewhat laborious separation of the LDH isoenzymes by electrophoresis.

HBD and LDH were determined in the skeletal muscle and hearts of the sheep fetuses and no treatment differences were found. LDH activity increased with age of the fetus (Figure 14). As with CPK, prenatal values determined were lower than values found in adult sheep. The ratio of $\mathrm{HBD} / \mathrm{LDH}$ was similar in the fetal heart $(71.3)$ to the adult heart, but in the fetal skeletal muscle the ratio was correspondingly greater $(38.5)$. No noticeable reduction occurred in the ratio, HBD/LDH, as the fetus grew older.

There were trends toward lower activities of CPK, HBD and LDH in vitamin E-deficjent animals and differences were pronounced in those 


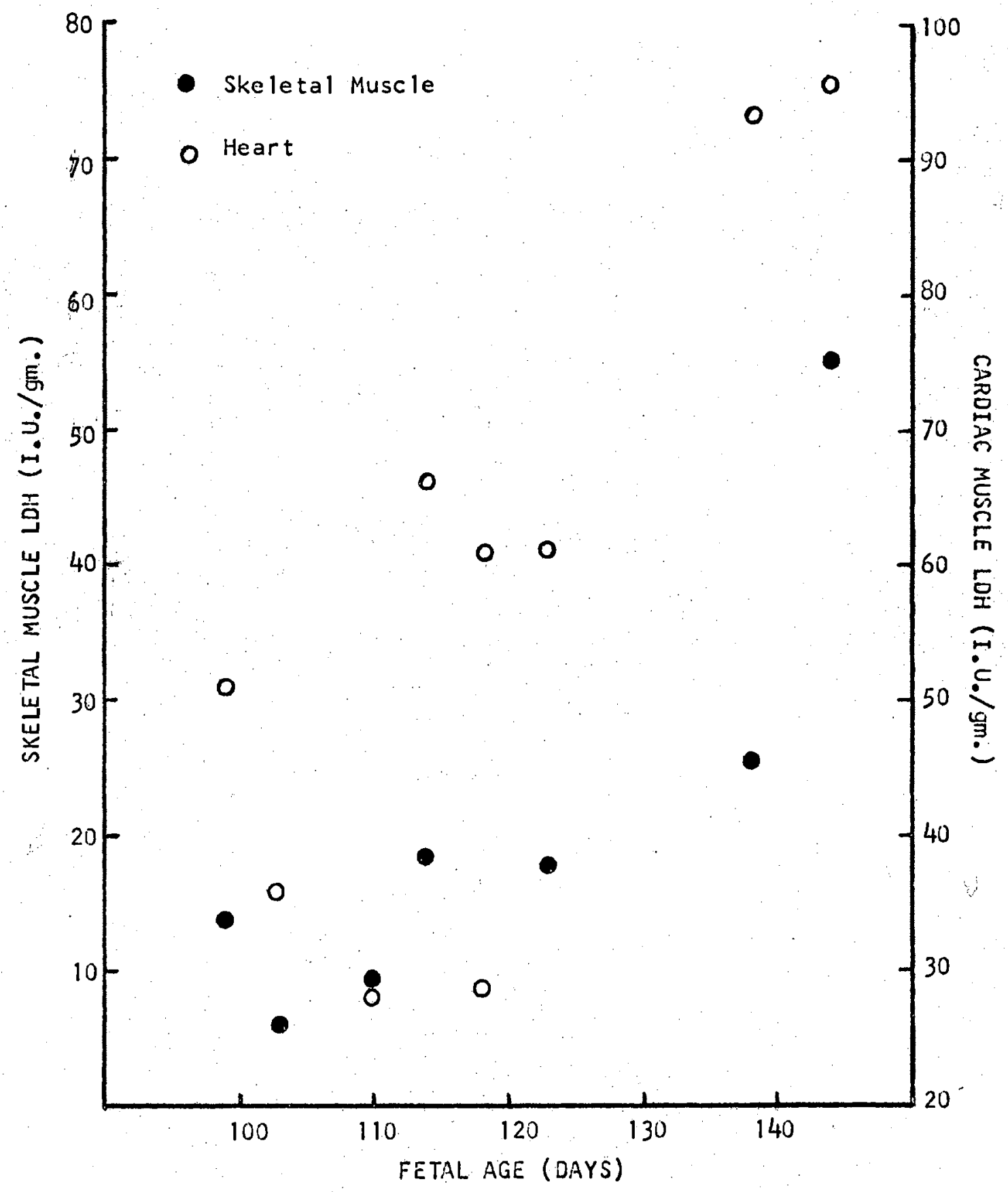

Figure 14. The Effect of Age on the Activity of Lactic Acid Dehydrogenase in Skeletal and Cardiac Muscle of the Ewes' Fetuses. (Each point represents one observation.) 
animals dying from the deficiency. Activities of CPK, HBD and LDH in the hearts were lowest in selenium-deficient animals but the significance of this observation is not clear.

\section{Tocopherols and Vitamin $A$ in Tissues}

Tocopherol concentrations (Table XVII) in all tissues except 1 iver were lower in the vitamin E-deficient ewes than in those ewes treated with vitamin E. There was great variation in liver tocopherol levels. A possible explanation concerns the fact that the tocopherol level in one vitamin E-treated sheep was $345 \mathrm{mcg} . / \mathrm{gm}$.; the sheep did not grow normally and weighed only $25 \mathrm{~kg}$. at sacrifice, but no serious pathological changes were noted. If this value is removed from the statistical analysis, then the effect of vitamin E deficiency on tocopherol concentration in liver is significant $(P<.005)$. If the tocopherol values are expressed on an organ basis, differences between vitamin Edeficient and vitamin E-treated ewes are also significant $(P<.05)$. Selenium had no effect $(P>.05)$ on the tissue tocopherol levels of vitamin E-treated ewes. Greater concentrations of tocopherol shown in this experiment in favor of the ewes not receiving selenium is largely a reflection of high tocopherol concentration in all tissues of the one ewe, which had an extremely high liver value. The results of the present experiment do not affirm the hypothesis that selenium enhances retention of vitamin E (Desai and Scott, 1965). Selenium dosage to vitamin E-treated rats increased the concentration of alpha-tocopherol in heart and liver, but the results were not consistent (Edwin et al. , 1961). Liver tocopherol values for the vitamin E-sufficient sheep in the present experiment are in agreement with values reported by 
TABLE XVII

THE EFFECT OF VITAMIN E AND SELENIUM ON THE CONCENTRATION

OF TOTAL TOCOPHEROLS IN LIVER, SKELETAL MUSCLE, HEART, KIDNEYS AND UTERUS AND PLACENTA OF THE EWES ${ }^{a}$

\begin{tabular}{|c|c|c|c|c|}
\hline \multirow[b]{2}{*}{ I tem } & \multicolumn{3}{|c|}{ Trea tment } & \multirow[b]{2}{*}{$S E^{b}$} \\
\hline & $\begin{array}{c}\text { Basal } \\
+ \\
\mathrm{Se}\end{array}$ & $\begin{array}{c}\text { Basal } \\
+ \\
\text { Vit. E }\end{array}$ & $\begin{array}{c}\text { Basal } \\
+ \\
\text { Vit. E } \\
+ \\
\text { Se }\end{array}$ & \\
\hline Number of animals & 6 & 6 & 6 & \\
\hline $\begin{array}{l}\text { Liver, } \mathrm{mcg} \mathrm{g}_{\circ} / \mathrm{gm}_{0} \\
\mathrm{mcg} / \mathrm{liver} / \mathrm{kg} \text {. live wt. }\end{array}$ & $\begin{array}{l}21.3 \\
261 .\end{array}$ & $\begin{array}{l}93.8 \\
1102 .\end{array}$ & $\begin{array}{l}47.2 \\
455 .\end{array}$ & $\begin{array}{l}29.2 \\
358 .\end{array}$ \\
\hline Skeletal muscle, $\mathrm{mcg} / \mathrm{gm}_{0}$ & $3.7^{c}$ & $12.1^{d}$ & $9.8^{d}$ & 1.6 \\
\hline $\begin{array}{l}\text { Heart, mcg./gm。 } \\
\mathrm{mc} g_{0} / \text { heart } / \mathrm{kg} \text {. live wto }\end{array}$ & $\begin{array}{r}5.2^{c} \\
19.6^{c}\end{array}$ & $\begin{array}{l}24.0^{d} \\
89.8^{d}\end{array}$ & $\begin{array}{l}19.4^{d} \\
71.4^{d}\end{array}$ & $\begin{array}{l}1.9 \\
9.8\end{array}$ \\
\hline $\begin{array}{l}\text { Kidneys, mcg./gm. } \\
\mathrm{mcg} / \mathrm{kidneys} / \mathrm{kg} \text {. live wt。 }\end{array}$ & $\begin{array}{r}5.7^{c} \\
11.7^{e}\end{array}$ & $\begin{array}{l}16.4^{d} \\
36.0^{f}\end{array}$ & $\begin{array}{l}15.6^{d} \\
25.4^{e, f}\end{array}$ & $\begin{array}{l}1.7 \\
6.6\end{array}$ \\
\hline $\begin{array}{l}\text { Uterus and placenta } \\
\mathrm{mcg} / \mathrm{gm}_{\circ}\end{array}$ & $2.7^{\mathrm{e}}$ & $9.1^{f}$ & $6.6^{f}$ & 1.3 \\
\hline
\end{tabular}

${ }^{a}$ Ewes who were on the basal treatment died.

b standard error of the treatment means.

$c, d$ Horizontal values on the same line bearing different super scripts differ significantly $(P<.005)$.

e, fHorizontal values on the same 1 ine bearing different superscripts differ significantly $(P<.05)$. 
Rousseau et al. (1957), but they did not measure liver tocopherols in vitamin E-deficient sheep. The results obtained for liver tocopherol in vitamin Eodeficient animals in the present experiment appear high. This could be a fault in technique in which another compound in liver was extracted besides tocopherol which fluoresced as does tocopherol. A compound was found in liver which severely inhibited the fluorescence of tocopherol. This is probably vitamin A (Duggan, 1959). Because of this inhibition, extremely dilute concentrations of liver extracts had to be used for measurements.

The results of the present experiment support the findings in rats (Edwin et al., 1961) and rabbits (Green et al., 1961) which show that tocopherol is widely distributed throughout the body. In rats, the uterus is especially susceptible to vitamin E deficiency as indicated by concentrations of tocopherols (Edwin et a1., 1961). In the rabbit, skeletal muscle is the more susceptible tissue (Green et al., 1961). The results of the present experiment indicate that both of these tissues have lower tocopherol concentrations than any of the others examined.

Esterified tocopherols (Table XVIII) were not present in liver samples and were found in one kidney sample. With the exception of one skeletal muscle sample, esterified tocopherols were not present in Vitamin Endeficient ewes. The amounts of esterified tocopherols found in tissues of vitamin Emtreated ewes were very low and could be dem tected in 50 percent of the samples only.

The total free tocopherol levels of fetal tissues are presented in Table XIX and values are lower than those found in the adult tissues. There were no significant differences $(P \$ 05)$ between treatments 


\section{TABLE XVIII}

THE EFFECT OF VITAMIN E AND SELENIUM ON THE RATIO OF ESTERIFIED. TOCOPHEROLS TO TOTAL TOCOPHEROLS IN SKELETAL MUSCLE, HEART, KIDNEYS AND UTERUS AND PLACENTA OF THE EWES ${ }^{a, b}$

\begin{tabular}{|c|c|c|c|c|}
\hline \multirow[b]{2}{*}{ I tem } & \multicolumn{3}{|c|}{ Treatment } & \multirow[b]{2}{*}{$S E^{C}$} \\
\hline & $\begin{array}{c}\text { Basal } \\
+ \\
\mathrm{Se}\end{array}$ & $\begin{array}{c}\text { Basa } 1 \\
+ \\
\text { Vit. E }\end{array}$ & $\begin{array}{c}\text { Basal } \\
+ \\
\text { Vit. E } \\
+ \\
\text { Se }\end{array}$ & \\
\hline Number of animals & 6 & 6 & 6 & \\
\hline $\begin{array}{l}\text { Skeletal muscle, } \% \\
\text { Heart, } \% \\
\text { Kidneys, } \% \\
\text { Uterus and placenta, } \%\end{array}$ & $\begin{array}{l}6.6 \\
0 \\
0 \\
0\end{array}$ & $\begin{array}{l}6.0 \\
7.0 \\
2.7 \\
4.4\end{array}$ & $\begin{array}{l}1.3 \\
5.1 \\
0 \\
8.2\end{array}$ & $\begin{array}{l}4.2 \\
2.5 \\
1.6 \\
4.1\end{array}$ \\
\hline
\end{tabular}

${ }^{a}$ Ewes who were on the basal treatment died.

${ }^{b}$ No esterified tocopherols were found in the liver of any animal.

${ }^{\mathrm{C}}$ Standard epror of the treatment means. 
TABLE XIX

THE EFFECT OF VITAMIN E AND SELENIUM ON THE CONCENTRATION

OF TOTAL FREE TOCOPHEROLS IN LIVER, SKELETAL MUSCLE, HEART AND KIDNEYS OF THE EWES' FETUSES ${ }^{a}$

\begin{tabular}{|c|c|c|c|c|}
\hline \multirow[b]{2}{*}{ I tem } & \multicolumn{3}{|c|}{ Treatment } & \multirow[b]{2}{*}{$S E^{b}$} \\
\hline & $\begin{array}{c}\text { Basal } \\
+ \\
\mathrm{Se}\end{array}$ & $\begin{array}{l}\text { Basal } \\
+ \\
\text { Vit. E }\end{array}$ & $\begin{array}{c}\text { Basal } \\
+ \\
\text { Vit. E } \\
+ \\
\text { Se }\end{array}$ & \\
\hline Liver & & & & \\
\hline $\begin{array}{l}\text { Number of fetuses } \\
\text { Concentration, } \mathrm{mcg} / \mathrm{gm}_{0}\end{array}$ & $\begin{array}{l}5 \\
5.0\end{array}$ & $\begin{array}{l}4 \\
7.9\end{array}$ & $\begin{array}{l}3 \\
8.6\end{array}$ & 1.5 \\
\hline $\begin{array}{l}\text { Ske letal muscle } \\
\text { Number of fetuses } \\
\text { Concentration, mcg。/gm。 }\end{array}$ & $\begin{array}{l}5 \\
2.8\end{array}$ & $\begin{array}{l}3 \\
4.0\end{array}$ & $\begin{array}{l}2 \\
3.6\end{array}$ & 0.9 \\
\hline $\begin{array}{l}\text { Heart } \\
\text { Number of fetuses } \\
\text { Concentration, } \mathrm{mc} \mathrm{g}_{0} / \mathrm{gm}\end{array}$ & $\begin{array}{l}2 \\
2.3\end{array}$ & $\begin{array}{l}5 \\
7.5\end{array}$ & $\begin{array}{l}3 \\
5.2\end{array}$ & 3.6 \\
\hline $\begin{array}{l}\text { Kidneys } \\
\text { Number of fetuses } \\
\text { Concentration, } \mathrm{mcg} / \mathrm{gm}_{\circ}\end{array}$ & $\begin{array}{l}3 \\
1.8\end{array}$ & $\begin{array}{l}3 \\
5.8\end{array}$ & $\begin{array}{l}1 \\
3.6\end{array}$ & 2.6 \\
\hline
\end{tabular}

${ }^{a_{N}}$ fetuses were obtained from ewes who were on the basal treatment。

${ }^{b}$ Standard error of the treatment means. 
a1though fetuses from vitamin E-deficient ewes contained lower concentrations than fetuses from vitamin E-treated ewes. The ratio of total free tocopherol concentration in adult tissues for ewes on the vitamin $E$ and selenium treatment over those on the selenium treatment varied from 2.2 for: liver to 3.7 for heart. The corresponding ratio was reduced in the fetuses to 1.7 for both 1 iver and skeletal muscle to 2.7 for heart. These findings agree with those of Whiting and Loos1i (1948) and Parrish et al. (1950), who measured the effect of vitamin E supplementation to the dam on concentration of tocopherol in the liver and plasma of the newborn. Tocopherols pass across the placenta, but only wi th difficulty, and the factors affecting this are not known. In this trial with sheep, selenium had no observable effect upon the phenomenon. Concentration of vitamin $A$ in liver was increased by vitamin $E$ but treatment differences were not as pronounced as found in plasma (Table $X X)$. Liver vitamin $A$ values obtained here are tenfold greater than those reported by Rousseau et a1. (1957); hence, no animal in this experiment should have suffered directly from vitamin A deficiency. The data for liver vitamin $A$ in sheep fetuses indicate that vitamin $E$ and selenium treatment might enhance the vitamin A status of the newborn, but treatment differences found in these experiments were not signifi$\operatorname{cant}(P>.05)$

\section{Genera1 Disscusion}

No live lambs were born to ewes on the basal diet, and successful production of weaned lambs occurred only in those ewes treated with both vitamin E and selenium. There were no observable pathological lesions of the reproductive tracts of ewes on any treatment. Work on 
TABLE XX

THE EFFECT OF VITAMIN E AND SELENIUM ON THE CONCENTRATION OF VITAMIN A IN LIVER OF THE EWES AND THEIR FETUSES ${ }^{a}$

\begin{tabular}{|c|c|c|c|c|}
\hline \multirow[b]{2}{*}{ I tem } & \multicolumn{3}{|c|}{ Treatment } & \multirow[b]{2}{*}{$S E^{b}$} \\
\hline & $\begin{array}{c}\text { Basal } \\
+ \\
\mathrm{Se}\end{array}$ & $\begin{array}{c}\text { Basal } \\
+ \\
\text { Vit. E }\end{array}$ & $\begin{array}{c}\text { Basal } \\
+ \\
\text { Vit. } \\
+ \\
\text { Se }\end{array}$ & \\
\hline \multicolumn{5}{|l|}{ Ewes } \\
\hline Number & 6 & 6 & 6 & \\
\hline \multicolumn{5}{|l|}{ Concentration } \\
\hline $\mathrm{mcg} / \mathrm{gm}$ 。 & 155.2 & 183.2 & 207.2 & 19.2 \\
\hline $\mathrm{mcg} / 1 \mathrm{iver} / \mathrm{kg}$. 1 ive $w t_{0}$ & 1858. & 2075 & 2001 & 211 \\
\hline \multicolumn{5}{|l|}{ Fetuses } \\
\hline Number & 5 & 4 & 3 & \\
\hline \multicolumn{5}{|l|}{ Concentration } \\
\hline $\mathrm{mcg} / \mathrm{gm}$. & 0.32 & 0.51 & 0.70 & 0.18 \\
\hline
\end{tabular}

Ewes who were on the basal treatment died.

${ }^{b}$ Standard eiror of the treatment means. 
the vitamin E-deficient pregnant rat indicates that resorption may take place as a result of fetal degeneration (King and Verma, 1967). In the present experiments, no degeneration or similar abnormality of vitamin E-deficient sheep fetuses was noticed, although there was a resorbed fetus from one ewe on the basal diet. It appears probable that the abortions from cows, bred on pastures in California associated with vitamin E. deficiency, probably were not the result of simple vitamin $E$ deficiency (Mace et al. , 1951). The same might apply to the work of Virtanen (1966) and Matrone et al. (1965) who encountered irregular estrus cycles. Matrone et al. (1965) prevented the reproductive difficulty with the addition of five percent alfalfa meal to the purified diet and it appears highly improbable that this alone would supply sufficient vitamin E. Similarly, it would appear that the weak or dead 1 ambs, born to ewes on a vitamin E-low diet, would be consequent to the chronic state of vitamin E deficiency in the same animals (Erlinger, 1968).

If the effect of vitamin $E$ on reproduction in sheep is an indirect one, it may be mediated through another nutrient. The results of these experiments indicated that $v i$ tamin $E$ and selenium additively increase vitamin A concentration of tissues especially plasma. There is a need to investigate the effect of vitamin $E$ and selenium on transfer of vitamin $A$ across the placenta.

No significant effect of vitamin $E$ or selenium on fertility of rams is demonstrated in these experiments. It is unfortunate that the rams used were not fertility tested before being placed on the experiment. If this had been done, it would have been easier to determine the cause of sterility in two of the rams used. 
Muscular dystrophy symptoms in the sheep used in these trials were encountered after the animals had developed functional rumens, and this confirms the earlier results of Erlinger (1968). Dietary unsaturated fatty acids are necessary to produce muscular lesions in immature calves or lambs (Blaxter, 1962a). Unsaturated fat is hydrogenated by the microflora of the rumen (Shorland et al., 1957). The proportion of unsaturated fat to total fat leaving the rumen is extremely small but this increases with passage through the gut (Lennox et al., 1968). The source and origin of unsaturated fat in the lower gut are the phospholipids of bile. Linoleic acid is the unsaturated fatty acid antagonistic to vitamin E for muscular dystrophy in the chicken (Hutcheson et al., 1963). Linolenic acid prevents deposition of arachidonic acid (formed from linoleic acid) in rat tissues and thus alleviates the 1inoleic acid-vitamin E antagonism (Witting and Horwitt, 1964). Amounts of linolejc and linolenic acids entering the body from the gut of the adult ruminant animal are small and in equal amount (Lennox and Garton, 1968). Therefore, the question undoubtedly arises as to what unsaturated fatty acid, if any, is antagonistic to vitamin $E$ in these ruminant tissues. Future investigations should concern the possibility that biohydrogenation of unsaturated fatty acids does not take place in the rumens of adult sheep fed synthetic diets similar to the one used in these experiments. Another possibility is to raise the level of dietary antioxidant to investigate if antioxidants will completely replace vitamin $E$ in these rations. Erwin et al., (1961) used diets containing 0.1 percent ethoxyquin for immature lambs and prevented dystrophy. Only 0.0125 percent ethoxyquin was used in the diets of these experiments. Further research is indicated for confirmation of selenium- 
deficiency symptoms in ruminants fed isynthetic diets. The purified diet used in the present experiments contained less than 0.005 ppm selenium and the minimum requirement for selenium appears to be 0.02 ppm (Thompson and Scott, 1968). Therefore, this diet, fed to sheep, would certainly have application in studying the biological role of se leni um. 


\section{CHAPTER V}

\section{SUMMARY}

The primary objective of this study was to determine the effect of vitamin $E$ and selenium on reproduction in sheep. Forty-eight ewe and twelve ram lambs (four months of age) were fed a purified diet containing urea as the sole nitrogen source, corn oil (one percent) and ethoxyquin $(0.0125$ percent). The experimental design was a two by two factorial. Subcutaneous injections of vitamin E (700 I.U. as dl alphatocopheryl acetate) and selenium (five mg. as sodium selenate) were given separately and in combination, at weekly intervals. After 140 days, one half the ewes were bred and treatments continued until lambing and for several additional months. The remaining ewes were bred and sacrificed at various stages of pregnancy to obtain tissues for pathological and biochemical analyses as we 11 as to observe fetal development. Various fertility tests were conducted in the rams after 140 days on trial. Blood samples were taken biweekly from half the ewes and all the rams for chemical analyses.

Sheep fed the basal diet died between the 80 th, and 230 th days of the trials. Treatment with vitamin E prevented the deaths of some of these animals. Selenium treatment delayed but did not prevent death. Death was sudden. Skeletal muscle necrosis was observed in all vitamin E-deficient sheep, post-mortem, and pathology was evident in the heart and kidneys of some of these animals. Growth was greatest in sheep 
treated with selenium. Satisfactory reproductive performance was only obtained in ewes treated with a combination of vitamin $E$ and selenium. Abortions occurred in some ewes on the selenium-deficient treatment. Myocardial necrosis was noted in lambs from other ewes on the same treatment. Lambs from selenium treated ewes did not survive beyond 56 days of age. One ewe fed the basal diet resorbed a fetus. No pathology was noted in the reproductive tracts or fetuses of any ewes, or in the testes of any rams. There were no significant differences in fertility of the rams.

$V$ itamin $E$ and selenium increased tocopherol concentration of blood plasma one week after the first injections. This response to selenium was reversed later in the trial. Vitamin A concentration in blood plasma was increased by both witamin $E$ and selenium. Blood hematocrit, hemoglobin and red cell concentrations were depressed in all animals at the start of the experiments and were lowest in the selenium-treated sheep. Elevated activities of glutamate-oxaloacetate transaminase, lactate dehydrogenase, alpha-hydroxy butyrate dehydrogenase, creatine phosphokinase and 1,6 diphosphofructoaldolasewere found in blood plasma of vitamin E-deficient sheep after 28 days on trial. The ratio of the activity of alpha-hydroxy butyrate dehydrogenase to the activity of lactate dehydrogenase in blood plasma was lower in selenium-treated sheep. Elevated activities of enzymes in blood plasma were found first in selenium-treated sheep but these elevations were transient. In most of the sheep on the basal treatment, activities of enzymes in blood plasma remained elevated until deatho

Creatine phosphokinase, lactate dehydrogenase and alpha-hydroxy butyrate dehydrogenase activities were lower in skeletal muscle of 
selenium-treated ewes. In fetal muscle, treatment had no effect on the activities of these enzymes. Total acid protease activity in liver was greater in vitamin E treated ewes than in ewes treated with both vitamin $E$ and selenium. Activities of bound acid protease and betamglucuronidase were greater in skeletal muscle of vitamin E-deficient ewes than in other ewes and greatest in ewes in the terminal stages of vitamin $E$ deficiency. Treatment had no effect on the bound or free activities of these enzymes in uterus and placenta. Concentration of tocopherol in skeletal muscle, heart, kidneys and uterus and placenta of ewes was increased by vitamin $E$ but not selenium. A similar response was observed in fetal tissues but differences were not significant. 


\section{TERATURE CITED}

Andersson, P. 1960. Nutritional muscular dystrophy in cattle. With special reference to the functional state of the thyroid. Acta. Path. Microbiol. Scandinavia, supp1. 134.

A.0.A.C. 1960. Official Methods of Analysis (9th. Ed.). Association of Official Agricultural Chemists. Washington, D. C.

Arscott, G. H. and J. E. Parker. 1967. Effectiveness of vitamin $E$ in reversing sterility of male chickens fed a diet high in linoleic acid. J. Nutr. 91:219.

Be11, M. C. 1967. Personal Communication.

Bergmeyer, Hans-Ulrich and Erich Bernt. 1965. Glutamate-pryuvate transaminase. In Methods of Enzymatic Analysis. Hans-Ulrich Bergmeyer, Ed., Academic Press, New York, N. Y., p. 846.

Bird, John W. C, and Nicholas A. B. Szabo. 1966. Lipid peroxidation in nutritional muscular dystrophy. Proc. Soc. Exp. Biol. Med. $117: 345$.

Blaxter, K. L. 1962a. Muscular dystrophy in farm animals: its cause and prevention. Proc. Nutr. Soc. 21:211.

Blaxter, K. L. 1962b. Vitamin $E$ in health and disease of cattle and sheep. Vitamins and Hormones 20:633.

Blaxter, Kenneth Lo and Fred Brown. 1952. Vitamin E in the nutrition of farm animals. Nutr. Abstr. and Rev. $22: 1$.

Blincoe, Clifton and W. B. Dye. 1958. Serum transaminase in white muscle disease. J. Animal Sci. 17:224.

Blincoe, Clifton and D. W. Marble. 1960. Blood enzyme interrelationships in white muscle disease. Am. J. Vet. Res. 21:866.

Boyazoglu, P. A., R. M. Jordan and R. J. Meade. 1967. Sulfur. seleniumvitamin E interrelations in ovine nutrition. J. Animal Sci. 26: 1390 。

Boyd, J. W. 1962. The comparative activity of some enzymes in sheep, cattle and rats - normal serum and tissue levels and changes during experimental liver necrosis. Res. Vet. Sci. 3:256. 
Boyd, J. W. 1964. Serum enzyme changes in lambs with experimentallyinduced acute muscular dystrophy. Res. Vet. Sci. 5:419.

Boyd, J. W. 1967. The rates of disappearance of 1-1actate dehydrogenase isoenzymes from plasma. Biochim. Biophys. Acta. 132:221.

Boyd, J. Wo 1968. Serum enzyme changes, muscular dystrophy and erythrocyte abnormalities in lambs fed on diets containing cod-liver oil 1 and maize oil, and the therapeutic effect of vitamin E. British J. Nutr。22:411.

Bratzler, J. W., J. K. Loos1i, V. N. Krukovsky and L. A. Maynard. 1950. Effect of the dietary level of tocopherols on their metabolism in swine. Jo Nutr. 42:59.

Bruns, Freidrich $H_{\text {. }}$ and Hans-U1rich Bergmeyer. 1965. Fructose-1,6diphosphate aldolase. In Methods of Enzymatic Analysis. HansUlrich Bergmeyer, Ed., Academic Press, New York, N. Y., p. 724.

Bul1, R. C. and J. E. Oldfield. 1967. Selenium involvement in the oxidation by rat liver tissue of certain tricarboxylic acid cycle intermediates. J. Nutr. $91: 237$.

Bunne1, R. H., J. E. Rousseau, Jr., H. D. Eaton and Geoffrey Beal1. 1954. Estimation of vitamin $A$ and carotenoids in calf liver. J. Dairy Sci. 37:1473.

Bunyan, J. do Green, A. To Diplock and D. Robinson. 1967a. Lysosomal enzymes and $v i$ tamin $E$ deficiency. 1. Muscular dystrophy, encephalomalacia and exudative diathesis in the chick. British J. Nutr. $21: 127$.

Bunyan, Jo, do Green, A. T, Diplock and D. Robinson. 1967b. Lysosomal enzymes and vitamin E deficiency. 2. Gestation - resorption in the rat. British d. Nutr. 21:137.

Bunyan, do, JoGreen, A. T. Diplock and D. Robinson. 1967c. Lysosomal enzymes and vitamin E deficiency. 3. Liver necrosis and testicular degeneration in the rat. British J. Nutr. 21:147.

Bunyan, J., A. To Diplock and J. Green. 1967d. Effects of vitamin E deficiency on total polyunsaturated fatty acids in rats and chicks. British 1. Nutr. 21:217.

Bunyan, J., Jo Green, Elspeth A. Murre11, A. T. Diplock and M. A. Cawthorne. 1968. On the postulated peroxidation of unsaturated lipids in the tissues of vitamin E-deficient rats. British J. Nutr. 22:97.

Card, L. Eo, H. H. Mitche 11 and T. S. Hami 1 ton. 1930. Fur ther studies on the vitamin E requirements of poultry. Proc. Poul. Sci. Assn., 22nd o meeting:29。 
Cardinet, George $H_{0}, J_{0} F_{0}$ Littrell and R. A. Freedland。 1967. Comparative investigations of serum creatine phosphokinase and glutamic-oxaloacetic transaminase activities in equine paralytic myoglobinuria. Res。Vet. Sci。 8:219.

Carper, H. A. and A。 Ro Roesler. 1968. A sensitive method for the determination of serum ornithine carbamyl transferase (OCT) in domestic animals. Am. J. Vet. Clin. Path. $2: 15$.

Chernick, Sidney $S_{0}$, Janet G. Moe, Gerald P. Rodnan and Klaus Schwarz. 1955. A metabolic lesion in dietary necrotic liver degeneration. J. Biol. Chem. $217: 829$.

Cheng, Dorothy Wei, Kar1 G. Braun, Bernard J. Braun and K. H. Udani. 1961. Tocopherol content of maternal and fetal rat tissues as related to vitamin $E$ intake during gestation. J. Nutr. 74:111.

Corwin, Laurence M. 1960. Studies on peroxidation in vitamin Edeficient rat liver homogenates. Arch. Biochem。97:51.

Corwin, Laurence M. and Klaus Schwarz. 1963. Relation of tocopherol to enzyme sulfhydryl sites. Arch. Biochem. 100:385.

DiAgostino, Barbaro A. 1951. Behaviour in vitro of the protozoa from the rumen of the goat in presence of vitamin E. Bull. Soc. Italian Biol. Sper. $27: 1444$.

Dancis,Joseph。1960。 Placental function and fetal nutrition. In The Placenta and Fetal Membranes. Claude A. Villee, Ed., The Williams and Wilkins Company, Philadelphia, Pa., P. 85.

Davis, George $K_{0}$ and $L_{0}$ A. Maynard. 1938. Cod-1iver oil tolerance in calves. Jo Dairy Sc i。 $21: 143$.

Desai, I. D. 1966. Activity of lysosomal enzymes in white muscle disease. Nature 209:1349.

Desai, I. D. and Mo Lo Scott. 1965. Mode of action of selenium in relation to biological activity of tocopherols. Arch. Biochem. $110: 309$.

Dicks, Martha Wo, do E. Rousseau, Jro, Ho D。 Eaton, Ro Teichman, A. P。 Grifo, Jro and $H_{0} A_{0}$. Kemmerer, Jr. 1959. Some interrelationships between vitamin $E$ and vitamin $A$ in Holstein calves. Jo Dairy Sci. $42: 501$.

Dingle, J. To, I. Mo Sharman and T. Moore. 1966. Nutrition and lysosomal activity. The influence of vitamin $A$ status on proteolytic activity of extracts from the livers and kidneys of rats. Bio. chem. d. $98: 476$.

Dinning, James S. 1962. Nucleic acid metabolism in vitamin E deficiency. Vitamins and Hormones 20:511。 
Draper, H. H., Jo Go Bergan, Mei Chiu, A. Saari Csallany and A. V. Boaro. 1964. A further study of the specificity of the vitamin E requirement for reproduction. J. Nutr. 84:395.

Duggan, Danie1 E. 1959. Spectrofluorometric determination of tocopherols. Arch. Biochem. 84:116.

Edwin, E. E., A. T. Diplock, Jo Bunyan and Jo Green. 1961. Studies on vitamin E. 6. The distribution of vitamin $E$ in the rat and the effect of alpha-tocopherol and dietary selenium on ubiquinone and ubichromenol in tissues. Biochem. J. 79:91.

Elliot, B. A, and Jo H. Wilkinson, 1961. Serum "lalphamydroxy butyric dehydrogenase" in myocardial infarction and in liver disease. Lancet, Apri 1 1, $: 698$.

Erlinger, Larry beland. 1968. Effect of a purified diet upon reproduc= tion in ewes. Mo $S$. Thesis. Oklahoma State University, still= water, Oklahoma.

Erwin, E. S., W. Sterner, R. SGordon, L. J. Machlin and L. S. Tureen. 1961. Etiology of muscular dystrophy in the lamb and chick. J. Nutr. $75: 45$.

Evans, Hepbert $M_{0}$ and $K_{\theta}$ Scott is shop. 1922, On the existence of a hither to unrecognized dietary factor essentiol for peproduction. Science $56: 650$

Evans, $H_{e} M_{e}$ and $G_{8} O_{9}$ Bumer 1927, The antisterility vitaminufat soluble E, Memoirs Unive Cal, 8:1,

Ewan, R. C., C. A. Baumann and $A_{0}$ ba Pope. 1968. Effects of selenium and vitamin $E$ on nutriftional muscular dystrophy in lambs. W. Animal Sci. 27:751.

Forbes, do Mo 1967. Factors affecting the gestation length in sheep. J. Agr. So, 68:191.

Freedland, R. $A_{0}, C_{0} A_{0}$ Hjerpe and C. E. Cornelíus. 1965. Comparative studies on plasma enzyme arivities in experimental hepatic nem crosis in the horse. Res. Vet. Scil. 6:18.

Gardner, R. W. and D. F. Hogue. 1967. Milk levels of selenium and vitamin E related to nutritional muscular dystrophy in the suckling lamb. do Nutro $93: 4+18$.

Garton, G. A. 1965. The digestion and assimilation of lipids. In Physiology of Digestion in the Ruminant. R. W. Dougherty, Ed., Butterworths, Washington, D. Co, p. 390.

Gianetto, R. and $C_{0}$ de Duve. 1955. Tissue fractionation studies. 4. Comparative study of the binding of acid phosphatase, beta-glucuronidase and cathepsin by rat-liver particles. Biochem. J. 59: 433. 
Gilbert, John J. and Guy A. Thompson, Jr. 1968. Alpha-tocophero1 control of sexuality and polymorphism in the rotifier Asplanchna. Science 159:734.

Gortner, Ross A., Jro and Joanne B. Ekwurtze1. 1965. Incidence of teratogeny induced by vitamin $E$ deficiency in the rat. Proc. Soc. Exp. Biol. Med. 119:1069.

Green, D. E. and D. C. Wharton. 1963. Stoichiometry of the fixed oxidation-reduction components of the electron transfer chain of beef heart mitrochondria. Biochem. Zeit. 338:335.

Green, J., A. T. Diplock, J. Bunyan and E. E. Edwin. 1961, Studies on vitamin E. 8. Vitamin E, ubiquinone and ubichromenol in the rab. bit. Biochem. J. $79: 108$.

Green, J., A. T. Diplock, J. Bunyan, D. McHale and I. R. Muthy. 1967. $V i$ tamin $E$ and stress. 1. Dietary unsaturated fatty acid stress and the metabolism of alpha-tocopherol in the rat. British $\mathrm{J}$. Nutr. 21:69.

Gullickson, T. W. and Jo B. Fitch. 1944. Effect of adding cod liver oil to the rations of dairy calves. J. Dairy Sci. 27:331.

Gullickson, T。 W., J. B. Fitch and L. O. Gilmore. 1948. Effect of feeding tocopherols to dairy cows on the quantity and the fat content of mi $1 \mathrm{k}$ produced. J. Dairy Sci. 31:557.

Gullickson, T. W., L. S. Palmer, W. L. Boyd, J. W. Nelson, F. C. O1son, C. E. Calverley and P. D. Boyer. 1949. Vitamin $E$ in the nutrition of cattle. 1. Effect of feeding vitamin $E$ poor rations on reproduction, health, milk production, and growth. J. Dairy Sci. $32: 495$.

Hancock, J。 L。 1952. The morphology of bull spermatozoa. J. Exp. Biol. $29: 445$.

Harris, Philip L., Marion I. Ludwig and Klaus Schwarz. 1958. Ineffectiveness of factor 3-active selenium compounds in resorptiongestation bioassay for vitamin E. Proc. Soc. Exp. Biol. Med. $97: 686$.

Hartley, W. J. and A. B. Grant. 1961. A review of selenium responsive diseases in New Zealand livestock. Fed. Proc. 20:679.

Hartley, W. J. 1963. Selenium and ewe fertility. Proc. New Zealand Soc. Anim. Prod. 23:20。

Hartley, Wo Jo 1967. Levels of selenium in animal tissues and methods of selenium administration. In Symposium: Selenium in Biomedecine, 0. H. Muth, Ed。, Avi Publishing Co., Westport, Conn. P. 
Henley, Keith S., Ellen Schmidt and Freidrich W. Schmidt。 1966. Enzymes in Serum. Thomas, Springfield, I11.

Henry, R. J. 1964. Clinical Chemistry. Principles and Technics. Harper and Row, New York, N. Y.

Hess, Benno. 1963. Enzymes in Blood Plasma. Academic Press, New York, N. Y。

Hi 11 man, Robert Wo 1957. Tocopherol excess in man. Creatinuria associated with prolonged ingestion. Am.J. Clin. Nutr. 5:597.

Hintz, H. F. and D。E. Hogue. 1964. Kidney beans (Phaseolus vulgaris) and the effectiveness of vitamin $E$ for prevention of nutritional muscular dystrophy in the chick. J. Nutr. 84:283.

Hogue, D.E. 1958. Selenium and muscular dystrophy. J. Am. Vet. Med. Assn。133:568 (Abstr。)。

Hopkins, L. L. Jr., A。 L. Pope and C. A. Baumann. 1964. Contrasting nutritional responses to $v i$ tamin $E$ and selenium in 1 ambs. J. Anima1 Sci. 23:674.

Hungate, R. E. 1966. The Rumen and its Microbes. Academic Press, New York, NoY。

Hutcheson, L. Mo, D. C. Hill and K. J. Jenkins. 1963. Influence of dietary fat on the efficacy of agents protecting against muscular dystrophy in the chick. Poul. Sci. 42:846.

Irving, J. T. 1958. The actions of alpha-tocopherol and protein upon the incisor toothe of the rat, and the influence of vitamin $A$ upon alpha-tocopherol activity. British J. Nutr. 12:196.

Jensen, Leo So 1968. Vitamin $E$ and essential fatty acids in avian reproduction. Fed. Proc. 27:914.

Jensen, Leo So and James McGinnis. 1960. Influence of selenium, antioxidants and type of yeast on vitamin E deficiency in the adult chicken. Jo Nutr. $72: 23$.

Kimble, Marion Stark. 1939. The photocolorimetric determination of vitamin $A$ and carotene in human plasma. J. Lab. C1in. Med. 24: 1055 .

King, Dorothy Wei and Kusum Verma. 1967. A histochemical study of embryonic rat liver in avitaminosis E. J. Nutr. 91:159.

Kitabchi, Abbas E, Paul B。 McCay, Mary P. Carpenter, Raul E. Trucco and Ranwe1 Caputto. 1960. Formation of malonaldehyde in vitamin E deficiency and its relation to the inhibition of gulonolactone oxidase. J. Biol. Chem。 235:1591. 
Kofler, Max, Paul Fo Sommer, Hans R. Bolliger, Benjamin Schmidli and Max Vecchi. 1962. Physicochemical properties and assay of the tocopherols. Vitamins and Hormones 20:407.

Kohlmeier, R。 $H_{0}$ and Wise Burroughs. 1963, Vitamin $A$ and $E$ interrelationships in high concentrate finishing rations for beef cattle. J. Animal Sci。22:1125 (Abstr.).

Koszalka, Thomas B., Karl E. Mason and George Krol. 1961. Relation of vitamin $E$ to proteolytic and autolytic activity of skeletal muscle. J. Nutr. $73: 78$.

Kuttler, Kenneth L。 and Donald W. Marble. 1959. The use of antioxidants and vitamin $E$ in preventing white muscle disease of lambs. Corne 11 vet. $49: 183$.

Kuttler, Kenneth L., Donald W. Marble and Clifton Blincoe. 1961. Serum and tissue residues following selenium injections in sheep. Am.J.Vet。 Res. $22: 422$.

Layne, E. 1957. Spectrophotometric and turbidimetric methods for measuring proteins. In Methods in Enzymology. S. P. Colowick and N. 0. Kaplan, Eds., 3:447.

Lee, D. J., Mei Chiu and Ho Ho Draper. 1965. Effect of vitamin E deficiency on ubiquinone levels in rat and rabbit liver. Nature $205: 288$.

Lennox, Aileen M. and G. A. Garton. 1968. The absorption of longchain fatty acids from the small intestine of the sheep. British J. Nutr. $22: 247$.

Lennox, Aileen。, A. K。 Lough and G. A. Garton. 1968. Observations on the nature and origin of lipids in the small intestine of the sheep. British doNutr。22:237.

Lowry, 01 iver Ho, Nira Jo Rosebrough, A. Lewis Farr and Rose J. Randa11. 1951. Protein measurement wi th the Folin phenol reagent. J. Biol. Chem. 193:265.

Lunca, N. and M. Musetescu. 1966. Corrective actions of vitamins A and $E$ in some forms of infertility in cows. Rev. Zooteh. Med. Vet. $16: 26$.

Mace, D. L. 1963. Vitamin E stops abortion in cows. State of Calif. Dept. Agric。 Bu11, 52:21。

Mann, T. 1964. The Biochemistry of Semen and of the Male Reproductive Tract. Wiley, New York, N. Y.

Maplesdon, D. Co, Jo D。 Harvey and H. D. Branion. 1960. Nutritional muscular dystrophy in calves: I. Addition of dried brewer's yeast, phosphorus and tocopherol to a dystrophogenic diet. Can. Vet. J. $1: 10$. 
Matrone, Gennard, Clara R. Bunn and J. J. McNei11. 1965. Studies of purified diets for growth and reproduction of the ruminant. $J$. Nutr. 86:154.

Meikle, J. E. S. and JoE. McFarlane. 1965. The role of lipid in the nutrition of the house cricket, Acheta Domesticus L. (Orthoptera: Gryllidae). Can。 J. Zoo1. $43: 87$.

Menefee, Max G., C。B. Mueller, T. B. Miller, J. Ko. Myers and A. L. Be11, 1964. Experimental studies in acute renal failure. II. Fine structural chariges in tubules associated with renal failure induced by globin. J. Exp. Med. 120:1139.

Moore, Thomas. 1940. The effect of vitamin E deficiency on the vitamin $A$ reserves of the rat. Biochem. J. 34:1321.

Moore, T. 1962. The history of selenium-vitamin E interrelationships. Proc.Nutr.Soc。21:179.

Moore, To, I.: M. Sharman, M. G. Stanton and J. T. Dingle. 1967. Nutritional and lysosomal activity. The influence of vitamin $E$ deficiency and its duration on the stability of lysosomes in the kidneys of rats. Biochem. J. 103:923.

Muth, 0. Ho 1955. White muscle disease (myopathy) in lambs and calves. I. Occurrence and nature of the disease under Oregon conditions. J.Am. Vet。Med。Assn。126:355.

Muth, O. H. Jo Ro Schubert and JoE. 01dfield. 1961. White muscle disease (myopathy) in lambs and calves. VII. Etiology and prophylaxis. Am。 JoVet。Res. $22: 466$.

01dfie1d, J. Eos JoR。 Schubert and 0。H. Muth. 1963. Implications of selenium in large animal nutrition. JoAgr. Food Chem. 11:388.

01son, R. E. and Paul C. Carpenter. 1967. The regulatory function of vitamin E。 Adv。Enz. Reg。 5:325.

Parrish, D。 B., G。 Ho Wise, Co E。 Latschar and J. S. Hughes. 1950. Effect of the prepartal diet of the cow on the placental and mammary transfer of tocopherols to the calf. J. Nutr. 40:193.

Paulson, G。 D。, A。 L。 Pope and C。 A。 Baumann. 1966. Lactic dehydrogenase isoenzymes in tissues and serum of normal and dystrophic 1ambs. Proc。Soc。 Exp。Biol. Med, 122:321.

Paulson, G. $D_{0}, C_{0} A_{9}$ Baumann and $A_{0}$ L. Pope. 1968. Metabolissm of $75 \mathrm{Se}-$ selenite, $75 \mathrm{Se}-$ selenate, $75 \mathrm{Se}-\mathrm{selenomethionine} \mathrm{and} 35 \mathrm{~S}-$ sulfate by rumen microorganisms in vitro. J. Animal Sci. 27:497.

Petersen, WoE。 1950. Dairy Science。 Lippincott, Co., Philadephia, $\mathrm{Pa}$ 。 
Roe, Joseph H. 1934. A colorimetric method for the determination of fructose in blood and urine. J. Biol. Chem. 107:15.

Roels, 0swald A。1967a。 Present knowledge of vitamin E. Nutr. Rev. $25: 33$.

Roels, Oswald A. 1967b. Present knowledge of coenzyme Q. Nutr. Rev. $25: 97$.

Rosenfeld, Irene and Orville A. Beath. 1964. Selenium. Geobotany, Biochemistry, Toxicity and Nutrition. Academic Press, New York, N. Y.

Rousseau, J. E. Jr., Mar tha W. Dicks, R. Teichman, C. F. Helmboldt, E. L. Bacon, R。 M. Prouty, Ko L. Dolge, H. D. Eaton, E. L. Jungherr and Geoffrey Beal1. 1957. Relationship between plasma, liver and dietary tocopherol in calves, lambs and pigs. J. Animal Sci. 16: 612.

Saffran, Murray and Orville Fo Denstedt. 1948. A rapid method for the determination of citric acid. J. Biol. Chem. 175:849.

Schmidt, Ellen. 1965. Glutamic dehydrogenase. In Methods of Enzymatic Analysis. Hans-U1rich Bergmeyer, Ed., Academic Press, New York, N. Y., P. 752.

Schubert, Jo Ro, O. H. Muth, J. Eo 01dfield and L. G. Remmert. 1961. Experimental results with selenium in white muscle disease of lambs and calves. Fed. Proc. $20: 689$.

Schwarz, K. 1958. Dietary necrotic liver degeneration - an approach to the problem of biochemical lesion. In Symposium on Liver Functions. Pub1.4. Am。Inst. Biol. Sci。, Eds., Washington, D. C.

Schwarz, K. 1961. Development and status of experimental work on factor 3-selenium. Fed. Proc. $20: 666$.

Scott, M. L。 1968. Trace elements in nutrition. Feedstuffs, Nov. $16,: 28$.

Seidel, John Co and Alfred E. Harper. 1960. Some observations on vitamin E deficiency in the guinea pig. J. Nutr. 70:147.

Shimazu, Fo and A. Lo Tappe 1. 1964. Selenoamino acids: Decrease of radiation damage to amino acids and proteins. Science 143:369.

Shor land, F" B., R。 O, Weenink, A。 To Johns and I. R. C. McDonald. 1957. The effect of sheep-rumen contents on unsaturated fatty acids. Biochem. do $67: 328$.

Shrift, Alex. 1961. Brochemical interrelationships between selenium and sulfur in plants and microorganisms. Fed. Proc. 20:695. 
Simon, Eric J., Charlotte S. Gross and Ade T. Milhorat. 1956. The metabolism of vitamin E. 1. The absorption and excretion of $d$ alpha tocophery1-5-methyl-c 14 -succinate. J. Biol. Chem. 221: 797.

Smith, Jack L., H. N. Bhagavan, R. Bleiler Hil1, S. Gaetani, P. B. Rama Rao, Q. E. Crider, B. Connor Johnson, Clifford H. Shunk, Arthur F. Wagner and Karl Folkers. 1963. Biological activities of compounds in the vitamin $E$, vitamin $K$ and coenzyme $Q$ groups in chicks, rabbits and rats. Arch. Biochem. 101:388.

Soderwa11, A. L. and John' Jacklet.' 19.63. Tö́opherol plasma values i.n fiemale hamsters. . Fed: Proc. $22: 51,3$ (Abstr..).

Tappe1, A. L. 1962. Vitamin E as the biological lipid antioxidant. $V$ itamins and Hormones $20: 493$.

Tappe1, A. Lo, H. Zalkin, K. A. Caldwe11, I. D. Desai and S. Shibko. 1962. Increased lososomal enzymes in genetic muscular dystrophy. Arch. Biochem. $96: 340$.

Thayer, R. T. and E. C. Ne1son. 1968. Personal Communication.

Thomas, Byron H., W. F. La Grange and C. C. Culbertson. 1942. Effect of 1 iberal wheat germ oil feeding on the reproduction of several breeds of sheep. J. Animal Sci. 1:61 (Abstr.).

Thompson, J. No and M. L. Scott. 1968. Selenium deficiency in chicks and its effect upon the requirement for vitamin E. Fed. Proc. 27:417 (Abstr.).

Thompson, S. Y., Jo Ganguly and S。 K. Kon. 1949. The conversion of beta-carotene to vitamin $A$ in the intestine. British J. Nutr. 3: 50 .

Tsen, C. C. and H. B. Collier, 1960. The protective action of tocoperhol against hemolysis of rat erythrocytes by dialuric acid. Can. J. Biochem 38:957.

Van Vleet, John F., B. Vincent Hall and Joseph Simon. 1968. A sequential $1 \mathrm{ight}$ and electron microscopic study of skeletal muscle degeneration in weanling rabbits. Am. J. Path. 52:1067.

Vasington, Frank D., Sherwood M. Reichard and Alvin Nason. 1960. Biochemistry of vitamin E. Vitamins and Hormones 18:43.

Virtanen, Artturi I. 1966。 Milk production of cows on protein-free feed. Science 153:1603.

Watkinson, J. H. 1960. Fluorometric determination of traces of selenium. Anal. Chem。 $32: 981$. 
We 1ch, James G。, W. Go Hoekstra, A, L。 Pope and P. Ho Phillipso 1960 . Effects of feeding fish liver oil, vitamin $E$ and selenium to ewes upon the occurrence of muscular dystrophy in their lambs. J. Animal Sci. 19:620.

White, Arnold A. and Walter C. Hess. 1958. Some alterations in serum enzymes in progressive muscular dystrophy. Proc. Soc. Exp. Biol. Med. $94: 541$.

Whiting, Frank and Jo Ko Loos1i. 1948. The placental and mammary transfer of tocopherols ( $v$ itamin E) in sheep, goats and swine. J. Nutr. $36: 721$.

Wiesmann, U., J. P. Colombo, A. Adam and R. Richterich. 1966. Determination of cysteine activated creatine kinase in serum. Enzym. Biol. Clin. 7:266.

Wi11man, J. P., J. K. Loos1i, S. A. Asde11, F. B. Morrison and P. 01 afson. 1945. Prevention and cure of muscular stiffness ("stiff-lamb" disease) in lambs. J. Animal Sci. 4:128.

Winters, Laurence M. and George Feuffe1. 1937. Studies on the physiology of reproduction in the sheep. IV. Fetal development. Minn. Agr. Exp. Sta. Tech. Bul1. 118.

Wiss, Oswald, Raymond $H_{\circ}$ Bunnel1 and Urs Gloor. 1962. Absorption and distribution of vitamin $E$ in the tissues. Vitamins and Hormones $20: 441$.

Witting, L. A. and M. K. Horwitt. 1964. Effect of degree of fatty acid unsaturation in tocopherol deficiency-induced creatinuria. J. Nutr. $82: 19$.

Wolf, Hans-Peter. 1965. 1-phosphofructoaldolase. In Methods of Enzymatic Analysis。 Hans-U1rich Bergmeyer, Ed.; Academic Press, New York, No Yo, po 732 .

Wright, $P_{0} L_{0}$ and $M_{0} C_{0}$ Be11. 1964。 Selenium-75 metabolism in the gestating ewe and fetal lamb: Effects of dietary alpha-tocopherol and selenium. Jo Nutr. 84:49.

Zalkin, H., A。 Lo Tappe1, K. A. Caldwe11, S. Shibko, I. D. Desai and T. A. Holliday。 1962. Increased lysosomal enzymes in muscular dystrophy of vitamin E-deficient rabbits. J. Biol. Chem. 237: 2678. 
APPENDICES 
APPENDIX A 
TABLE XXI

THE EFFECT OF VITAMIN E AND SELENIUM ON THE HEMATOCRIT IN BLOOD OF THE EWES

\begin{tabular}{|c|c|c|c|c|c|}
\hline \multirow[b]{2}{*}{ I tem } & \multicolumn{4}{|c|}{ Treatment } & \multirow[b]{2}{*}{$S E^{a}$} \\
\hline & Basal & $\begin{array}{c}\text { Basal } \\
+ \\
\mathrm{Se}\end{array}$ & $\begin{array}{c}\text { Basal } \\
+ \\
\text { Vit. E }\end{array}$ & $\begin{array}{c}\text { Basal } \\
+ \\
\text { Vit. E } \\
+ \\
\text { Se }\end{array}$ & \\
\hline $\begin{array}{l}\text { Number of ewes } \\
\text { Ratio, \% }\end{array}$ & 6 & 6 & 6 & 6 & \\
\hline \multicolumn{6}{|l|}{ On day } \\
\hline 14 & 28.0 & 27.2 & 28.1 & 26.9 & 3.32 \\
\hline 28 & $24.5^{b}$ & $22.8^{b, c}$ & $28.1^{d}$ & $21.7^{c}$ & 0.76 \\
\hline 42 & $31.3^{b, c}$ & $28.8^{b, d}$ & $32.3^{c}$ & $27.8^{d}$ & 1.18 \\
\hline 56 & 32.5 & 32.5 & 35.2 & 34.0 & 1.25 \\
\hline 70 & 37.0 & 36.2 & 36.7 & 36.8 & 1.26 \\
\hline 84 & $35.9^{b, c}$ & $33.4^{b}$ & $37.7^{c}$ & $34.2^{b, c}$ & 1.29 \\
\hline 98 & 35.9 & 38.6 & 36.0 & 36.0 & 1.20 \\
\hline 112 & 37.0 & 37.1 & 36.3 & 35.6 & 1.35 \\
\hline 126 & 40.2 & 37.4 & 36.6 & 38.6 & 1.30 \\
\hline 140 & 37.1 & 37.0 & 37.9 & 38.1 & 1.26 \\
\hline
\end{tabular}

${ }^{\mathrm{a}}$ Standard error of the treatment means.

b-d Horizontal values on the same line bearing different superscripts differ significantly $(P \ldots .01)$. 
TABLE XXII

THE EFFECT OF VITAMIN E AND SELENIUM ON THE CONCENTRATION OF HEMOGLOBIN IN THE BLOOD OF THE EWES

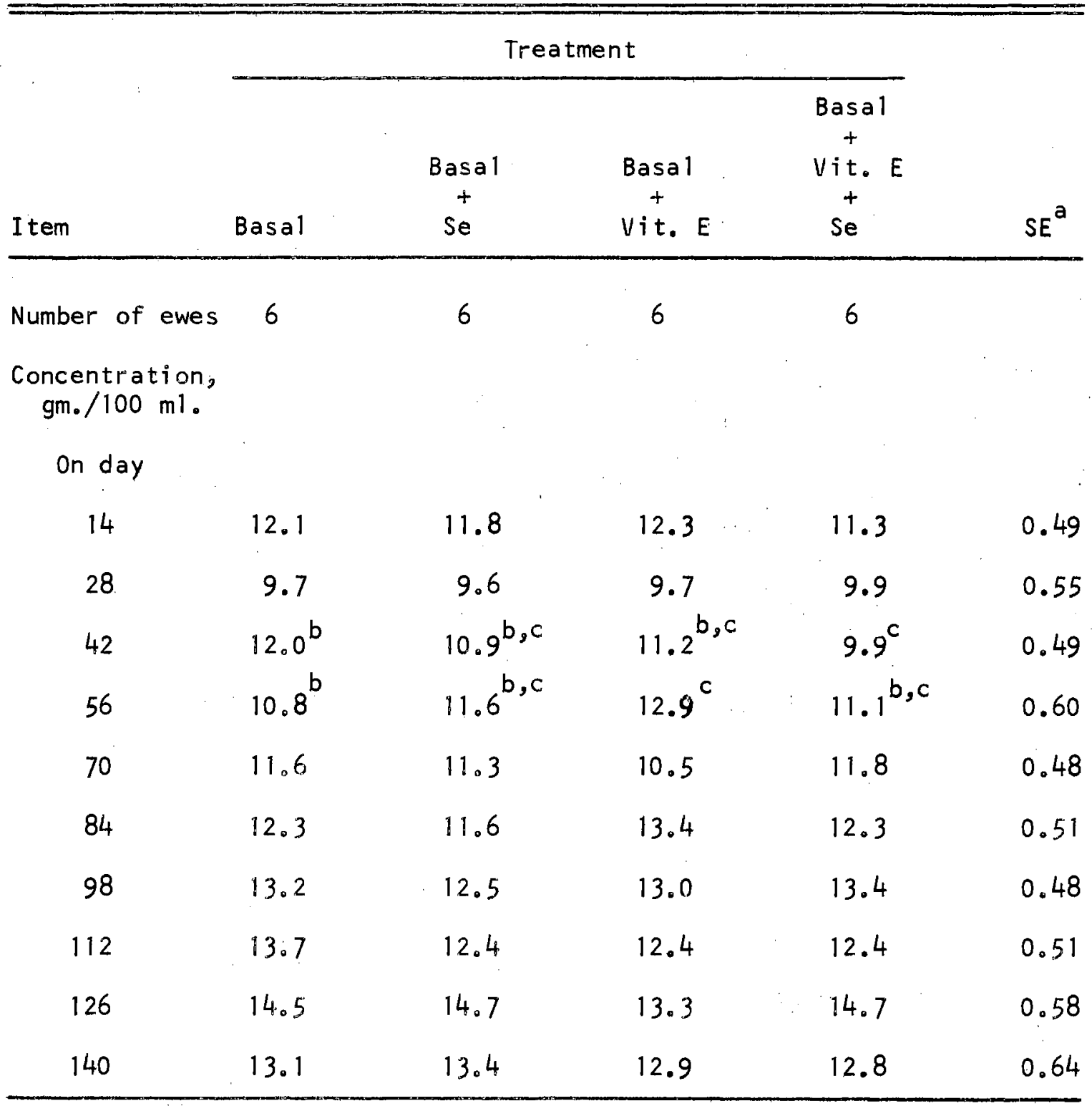

${ }^{a}$ Standard error of the treatment means.

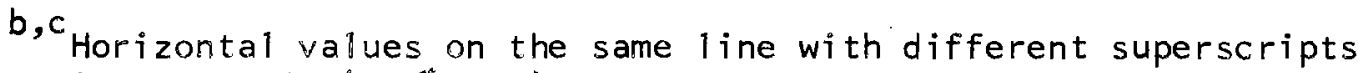
differ significantly $(P \& .05)$. 
TABLE XXIII

THE EFFECT OF VITAMIN E AND SELENIUM ON THE CONCENTRATION

OF RED BLOOD CELLS IN THE BLOOD OF THE EWES

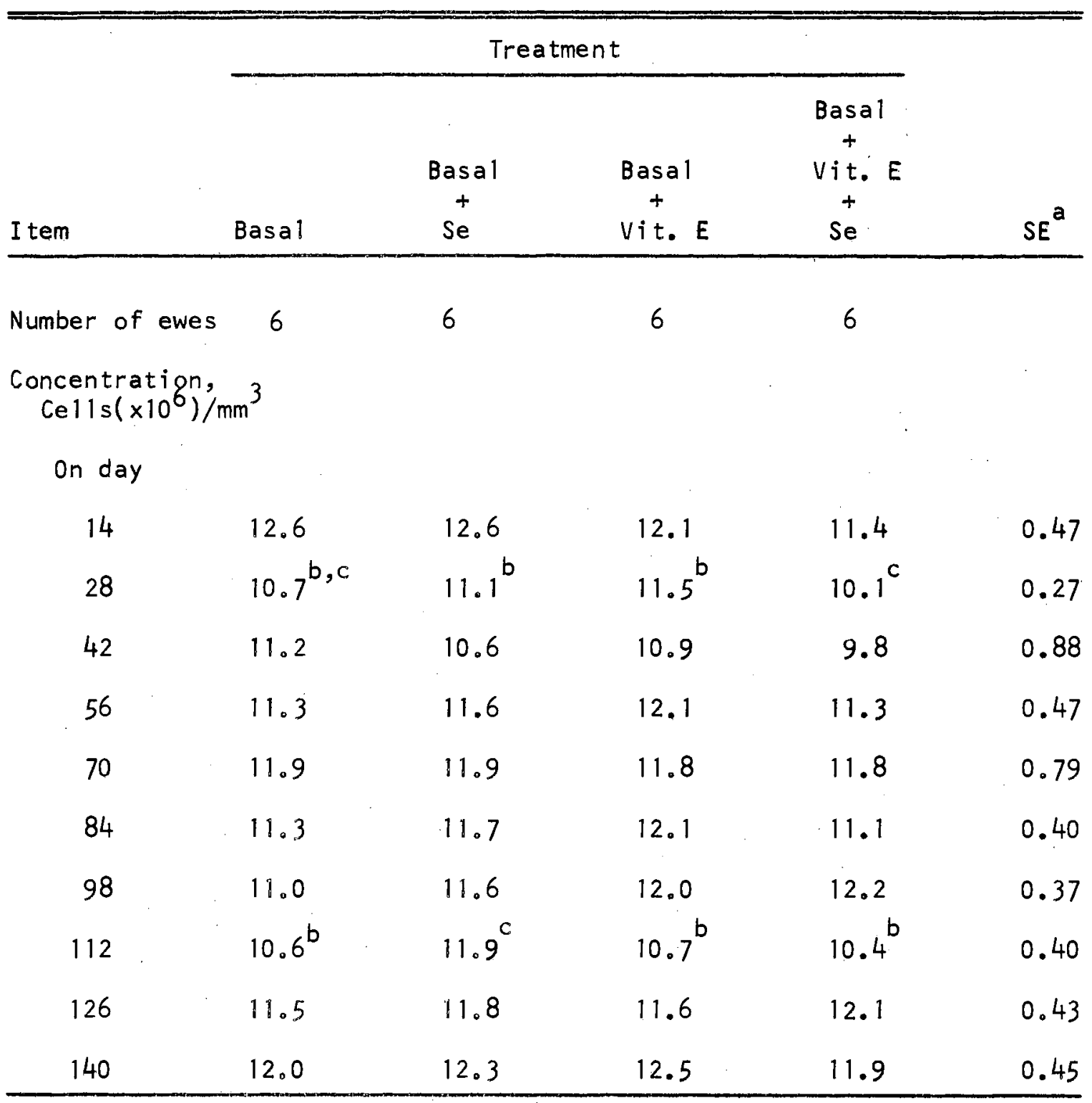

${ }^{\text {a }}$ Standard error of the treatment means.

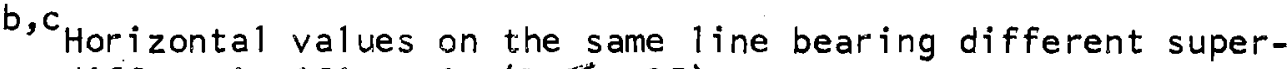
scripts differ significantly ( $P$.05). 
TABLE XXIV

THE EFFECT OF VITAMIN E AND SELENIUM ON HEMATOCRIT

IN THE BLOOD OF THE RAMS

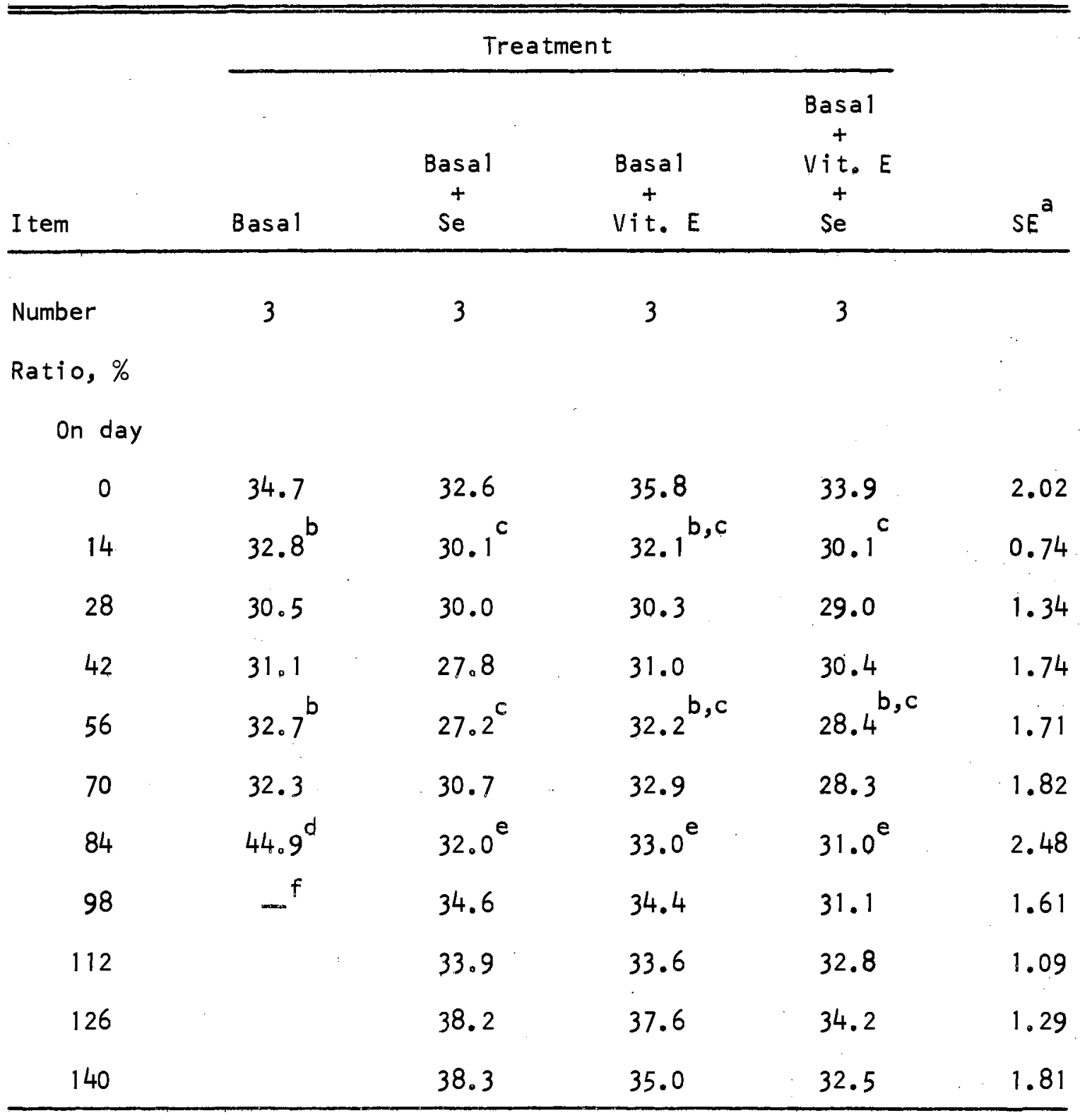

astandard error of the treatment means.

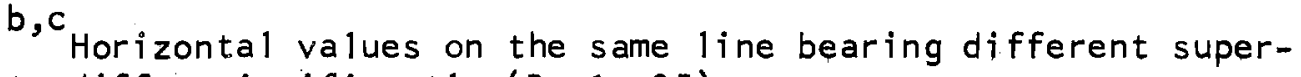
scripts differ significantly. $(P \leq .05)$.

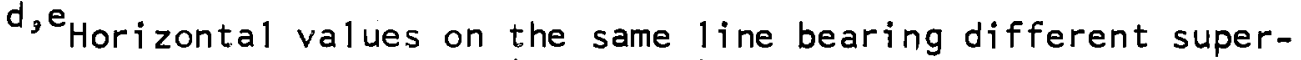
scripts differ significantly $(P \leftarrow 01)$.

f Rams who were on the basal treatment died. 
TABLE XXV

THE EFFECT OF VITAMIN E AND SELENIUM ON THE CONCENTRATION OF HEMOGLOBIN IN THE BLOOD OF THE RAMS

\begin{tabular}{|c|c|c|c|c|c|}
\hline \multirow[b]{2}{*}{ I tem } & \multicolumn{4}{|c|}{ Treatment } & \multirow[b]{2}{*}{$S E^{a}$} \\
\hline & Basal & $\begin{array}{c}\text { Basal } \\
+ \\
\mathrm{Se}\end{array}$ & $\begin{array}{c}\text { Basal } \\
+ \\
\text { Vit. E }\end{array}$ & $\begin{array}{c}\text { Basal } \\
+ \\
\text { Vit. E } \\
+ \\
\text { Se }\end{array}$ & \\
\hline \multicolumn{6}{|c|}{$\begin{array}{l}\text { Concentration, } \\
\text { gm./100 } \mathrm{ml}\end{array}$} \\
\hline On day & & & & & \\
\hline 0 & 12.2 & 11.8 & 13.2 & 12.0 & 0.95 \\
\hline 14 & $10.5^{b}$ & $9.8^{b, c}$ & $10.2^{b}$ & $9.1^{c}$ & 0.32 \\
\hline 28 & 10.6 & 9.8 & 11.0 & 9.8 & 0.45 \\
\hline 42 & 9.2 & 8.7 & 9.6 & 9.0 & 0.58 \\
\hline 56 & 9.5 & 8.4 & 9.5 & 9.4 & 0.57 \\
\hline 70 & 10.5 & 10.3 & 9.9 & 9.3 & 0.61 \\
\hline 84 & $13.7^{d}$ & $9.9^{e}$ & $10.7^{\mathrm{e}}$ & $10.4^{\mathrm{e}}$ & 0.56 \\
\hline 98 & $-f$ & 11.0 & 9.4 & 10.8 & 0.84 \\
\hline 112 & & 10.9 & 11.7 & 11.1 & 0.52 \\
\hline 126 & & 12.1 & 12.0 & 10.6 & 0.45 \\
\hline 140 & & 11.7 & 11.8 & 10.8 & 1.06 \\
\hline
\end{tabular}

${ }^{\text {a }}$ Standard error of the treatment means.

b,c Horizontal values on the same line bearing different superscripts differ significantly $(P<.05)$.

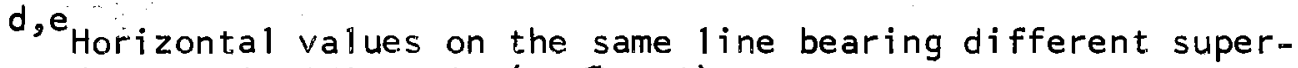
scripts differ significantly $(P<.01)$.

Rams who were on the basal treatment died. 
TABLE XXVI

THE EFFECT OF VITAMIN E AND SELENIUM ON THE CONCENTRATION OF PROTEIN IN BLOOD PLASMA OF THE EWES

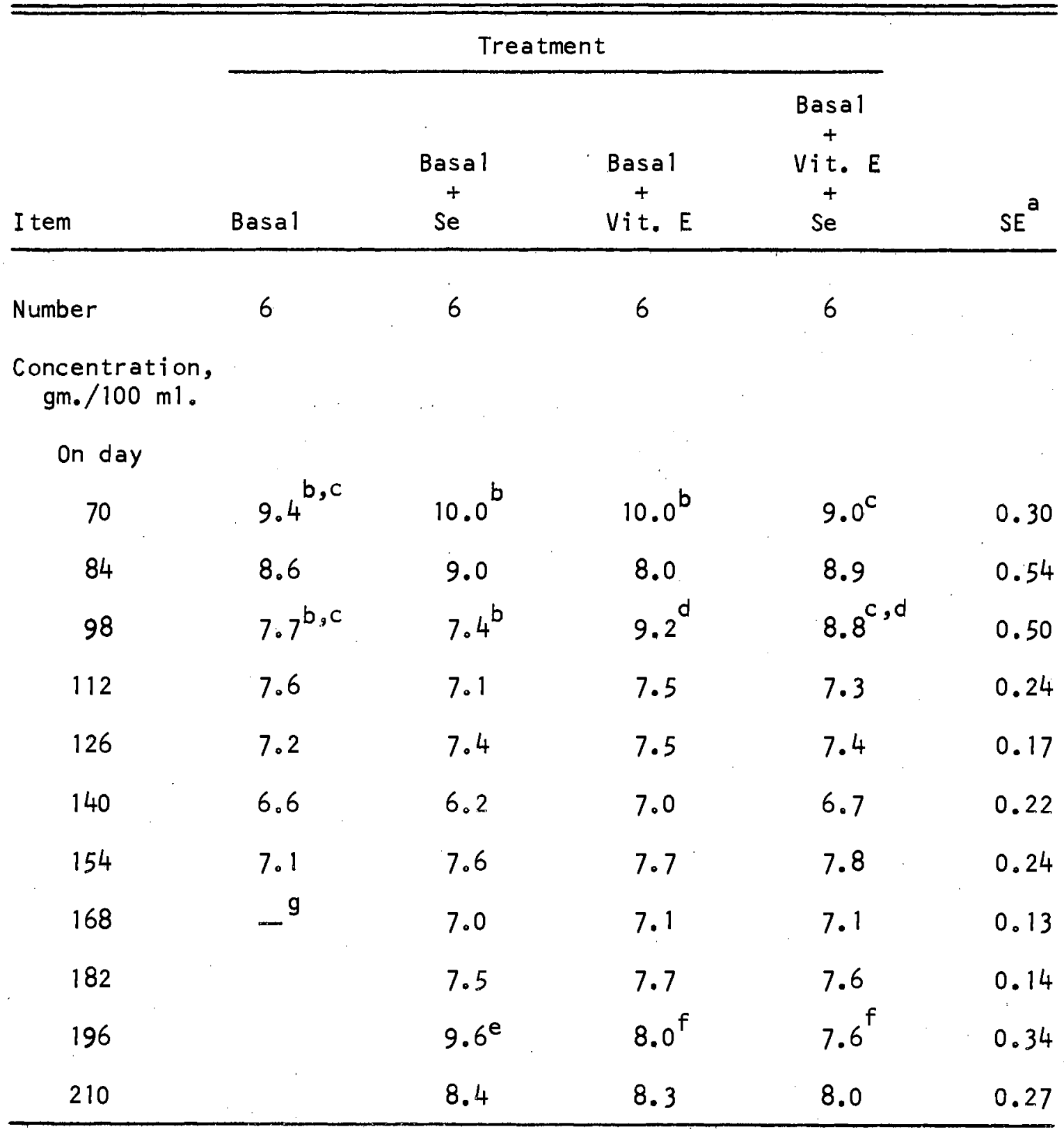

$\mathrm{a}_{S}$ tandard error of the treatment means.

$b-d$ Horizontal values on the same line bearing different superscripts differ significantly $(P<.05)$.

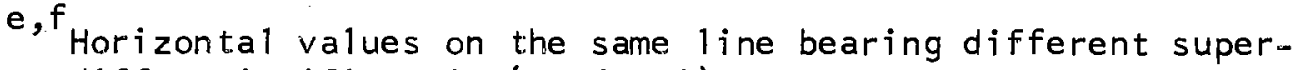
scripts differ significantly $(P<.01)$.

gewes who were on the basal treatment died. 
APPENDIX B 
TABLE XXVII

THE EFFECT OF VITAMIN E AND SELENIUM ON THE PROXIMATE ANALYSES OF THE EWES' MILK ${ }^{a}$

\begin{tabular}{|c|c|c|c|c|}
\hline \multirow[b]{2}{*}{ I tem } & \multicolumn{3}{|c|}{ Treatment } & \multirow[b]{2}{*}{$S E^{b}$} \\
\hline & $\begin{array}{c}\text { Basal } \\
+ \\
\mathrm{Se}\end{array}$ & $\begin{array}{c}\text { Basal } \\
+ \\
\text { Vit. } E\end{array}$ & $\begin{array}{c}\text { Basal } \\
+ \\
\text { Vit. E } \\
+ \\
\text { Se }\end{array}$ & \\
\hline Number of ewes ${ }^{c}$ & 1. & 3 & 5 & \\
\hline \multicolumn{5}{|l|}{ Proximate analysis } \\
\hline $\begin{array}{l}\text { Protein, } \% \\
\text { Fat, } \% \\
\text { Ash, } \% \\
\text { Total solids, \% }\end{array}$ & $\begin{array}{l}5.3 \\
0.9 \\
0.96 \\
12.3\end{array}$ & $\begin{array}{c}3.8 \\
5.4 \\
0.93 \\
15.2\end{array}$ & $\begin{array}{l}4.2 \\
5.1 \\
0.86 \\
15.1\end{array}$ & $\begin{array}{l}0.3 \\
0.7 \\
0.01 \\
0.6\end{array}$ \\
\hline
\end{tabular}

${ }^{a}$ Ewes who were on the basal treatment died.

${ }^{b}$ standard error of the treatment means.

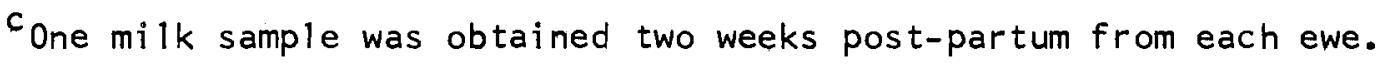


APPENDIX C 
TABLE XXVIII

NORMAL MEAN VALUES AND RANGES OBTAINED FOR THE ACTIVITIES OF SEVERAL ENZYMES IN BLOOD PLASMA OF SHEEPa

\begin{tabular}{|c|c|c|c|c|c|c|}
\hline \multirow[b]{3}{*}{ Enzyme } & \multicolumn{5}{|c|}{$\operatorname{Sex}$} & \\
\hline & \multicolumn{3}{|c|}{ Ewes } & \multicolumn{3}{|c|}{ Rams } \\
\hline & $\begin{array}{c}\text { Number } \\
\text { of } \\
\text { values }\end{array}$ & Mean & Range ${ }^{c}$ & $\begin{array}{c}\text { Number } \\
\text { of } \\
\text { values }\end{array}$ & Mean & Range $^{c}$ \\
\hline GOT & 102 & 32.0 & $2.6-61.4$ & 30 & 33.8 & $15.0-52.6$ \\
\hline CPK & 18 & 3.3 & $0-11.3$ & 30 & 7.0 & $0-16.6$ \\
\hline LDH & 12 & 243.0 & $134.6-351.4$ & 30 & 521.4 & $117.2-925.6$ \\
\hline $\mathrm{HBD}$ & 12 & 179.3 & $102.1-256.5$ & 30 & 342.6 & $91.8-593.4$ \\
\hline GDH & & & & 12 & 12.8 & $0-42.4$ \\
\hline GP T & & & & 12 & 12.9 & $4.3-21.5$ \\
\hline FDA & & & & 12 & 31.9 & $14.9-48.9$ \\
\hline PFA & & & & 6 & 14.4 & $4.8-24.0$ \\
\hline ICDH & & & & 6 & 6.0 & $0-14.8$ \\
\hline
\end{tabular}

$a_{V a l u e s}$ are from samples obtained in sheep fed the basal diet and treated with both $v i$ tamin $E$ and selenium.

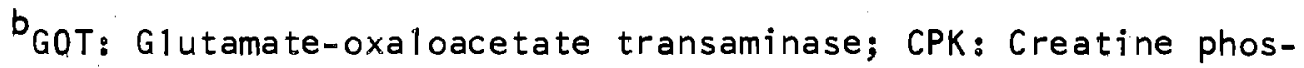
phokinase; LDH: Lactate dehydrogenase; HBD: Alpha-hydroxy butyrate dehydrogenase; GDH: Glutamate dehydrogenase; GPT: Glutamate-pyruvate transaminase; FDA: 1,6 Diphosphofructoaldolase; P.FA: 1, Phosphofructoaldolase; ICDH: Isocitrate dehydrogenase.

$\mathrm{c}_{\text {Range }}=$ Mean $\stackrel{+}{-}$ Two standard deviations. 
APPENDIX D 
TABLE XXIX

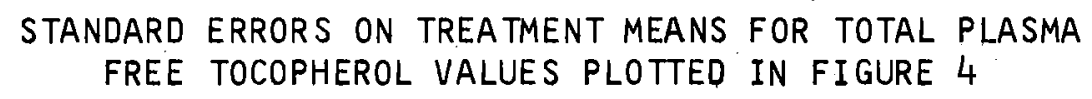

\begin{tabular}{|c|c|}
\hline & \\
\hline Time on Trial & Standard Error \\
\hline Days & $\mathrm{mcg} \cdot / 100 \mathrm{ml}$. plasma \\
\hline 14 & 6.5 \\
\hline 28. & 10.3 \\
\hline 56 & 9.9 \\
\hline 70 & 8.4 \\
\hline 84 & 8.8 \\
\hline 98 & 11.0 \\
\hline 112 & 15.4 \\
\hline 126 & 13.8 \\
\hline 140 & 14.8 \\
\hline 168 & 29.2 \\
\hline 196 & 77.0 \\
\hline 210 & 58.1 \\
\hline 224 & 37.4 \\
\hline 252 & 34.2 \\
\hline
\end{tabular}


TABLE XXX

STANDARD ERRORS ON TREATMENT MEANS FOR PLASMA GLUTAMATE-OXALOACETATE TRANSAMINASE VALUES PLOTTED IN FIGURE 6

\begin{tabular}{|c|c|}
\hline & \\
\hline Time on Trial & Standard Error \\
\hline Days & I.U./1. plasma \\
\hline 14 & 4.0 \\
\hline 28 & 10.7 \\
\hline 42 & 21.6 \\
\hline 70 & 71.0 \\
\hline 84 & 25.4 \\
\hline 98 & 48.1 \\
\hline 126 & 61.3 \\
\hline 140 & 67.1 \\
\hline 154 & 51.4 \\
\hline 168 & 38.5 \\
\hline 182 & 188.6 \\
\hline 196 & 161.8 \\
\hline 210 & 26.5 \\
\hline 224 & 97.1 \\
\hline 238 & 35.9 \\
\hline
\end{tabular}


TABLE $X X X I$

STANDARD ERRORS ON TREATMENT MEANS FOR PLASMA

GLUTAMATE-OXALOACETATE TRANSAMINASE VALUES

PLOTTED IN FIGURE 7

\begin{tabular}{cc}
\hline & Item \\
\hline Dime on Trial & Standard Error \\
\hline 0 & I.U./1. plasma \\
14 & 3.5 \\
28 & 3.3 \\
42 & 6.3 \\
56 & 88.6 \\
70 & 21.8 \\
84 & 39.9 \\
98 & 271.6 \\
112 & 18.4 \\
126 & 6.9 \\
140 & 11.6 \\
\hline
\end{tabular}


TABLE XXXII

STANDARD ERRORS ON TREATMENT MEANS FOR PLASMA

CREATINE PHOSPHOKINASE VALUES PLOTTED

IN FIGURE 8

\begin{tabular}{cc}
\hline & Item \\
\hline Time on Trial & Standard Error \\
\hline 0 & I.U./1. plasma \\
14 & 0.8 \\
28 & 1.1 \\
42 & 1.6 \\
56 & 91.3 \\
70 & 7.1 \\
84 & 22.0 \\
98 & 175.6 \\
112 & 3.9 \\
126 & 0.7 \\
140 & 2.8 \\
\hline
\end{tabular}




\section{TABLE XXX:III}

STANDARD ERRORS ON TREATMENT MEANS FOR PLASMA ALPHA-HYDROXY BUTYRATE DEHYDROGENASE VALUES PLOTTED IN FIGURE 9

\begin{tabular}{cc}
\hline & Item \\
\hline Time on Trial & Standard Error \\
Days & I.U./1. plasma \\
0 & 32.4 \\
14 & 23.3 \\
28 & 39.1 \\
42 & 248.9 \\
56 & 42.2 \\
70 & 292.5 \\
84 & 400.4 \\
98 & 101.7 \\
112 & 46.4 \\
126 & 34.3 \\
140 & 34.8 \\
\hline
\end{tabular}


TABLE XXXIV

STANDARD ERRORS ON TREATMENT MEANS FOR PLASMA

LACTATE DEHYDROGENASE VALUES PLOTTED

IN FIGURE 10

\begin{tabular}{cc}
\hline \multicolumn{1}{c}{ Item } \\
\hline Time on Trial & Standard Error \\
Days & I.U./1. plasma \\
0 & 42.2 \\
14 & 21.7 \\
28 & 66.2 \\
42 & 342.7 \\
56 & 69.0 \\
70 & 591.5 \\
84 & 793.2 \\
98 & 145.1 \\
112 & 62.8 \\
126 & 140.1 \\
140 & 60.4 \\
\hline
\end{tabular}




\author{
VITA \\ 3 \\ Jock Gordon Buchanan-Smith \\ Candidate for the Degree of \\ Doctor of Philosophy
}

Thesis: EFFECTS OF VITAMIN E AND SELENIUM DEFICIENCIES IN SHEEP FED A PURIFIED DIET DURING GROWTH AND REPRODUCTION

Major Field: Anima1 Nutrition

Biographica1:

Personal Data: Born in Edinburgh, Scot1and, March 9, 1940, the son of Alick Drummond and Mary Kathleen Buchanan-Smith.

Education: Graduated from Trinity College, Glenalmond, Scotland in 1958; received the Bachelor of Science degree in Agriculture from the University of Aberdeen, Scotland in 1962; received the Bachelor of Science degree in Animal Science from Iowa State University, Ames, I owa in 1963; received the Master of Science degree with a major in Animal Husbandry from Texas Technological College, Lubbock, Texas in 1965; completed the requirements for the Doctor of Philosophy. degree at Oklahoma State University in May, 1969.

Professional Experience: Research Assistant in the Department of Animal Husbandry, Texas Technological College, Lubbock, Texas, 1964-65; Research and Teaching Assistant in the Department of Animal Science, Oklahoma State University, Stillwater, Oklahoma, 1965-1969.

Professional Societies: Sigma Xi; Phi Kappa Phi; Alpha Zeta; American Society of Animal Science; American Association for the Advancement of Science. 